\title{
Werken in de openbare apotheek
}

Citation for published version (APA):

de Grip, A., \& Sieben, I. J. P. (2002). Werken in de openbare apotheek. Researchcentrum voor Onderwijs en Arbeidsmarkt, Faculteit der Economische Wetenschappen. ROA Reports No. 13 https://doi.org/10.26481/umarep.2002013

Document status and date:

Published: 01/01/2002

DOI:

10.26481/umarep.2002013

Document Version:

Publisher's PDF, also known as Version of record

\section{Please check the document version of this publication:}

- A submitted manuscript is the version of the article upon submission and before peer-review. There can be important differences between the submitted version and the official published version of record.

People interested in the research are advised to contact the author for the final version of the publication, or visit the DOI to the publisher's website.

- The final author version and the galley proof are versions of the publication after peer review.

- The final published version features the final layout of the paper including the volume, issue and page numbers.

Link to publication

\footnotetext{
General rights rights.

- You may freely distribute the URL identifying the publication in the public portal. please follow below link for the End User Agreement:

www.umlib.nl/taverne-license

Take down policy

If you believe that this document breaches copyright please contact us at:

repository@maastrichtuniversity.nl

providing details and we will investigate your claim.
}

Copyright and moral rights for the publications made accessible in the public portal are retained by the authors and/or other copyright owners and it is a condition of accessing publications that users recognise and abide by the legal requirements associated with these

- Users may download and print one copy of any publication from the public portal for the purpose of private study or research.

- You may not further distribute the material or use it for any profit-making activity or commercial gain

If the publication is distributed under the terms of Article $25 \mathrm{fa}$ of the Dutch Copyright Act, indicated by the "Taverne" license above, 


\section{Werken in de openbare apotheek}

ROA-R-2002/13

Andries de Grip

Inge Sieben

\section{Researchcentrum voor Onderwijs en Arbeidsmarkt}

Faculteit der Economische Wetenschappen en Bedrijfskunde Universiteit Maastricht

Maastricht, oktober 2002 
ISBN 90-5321-345-7

sec02.134.doc 


\section{Inhoud}

Bladzijde

Voorwoord

Resumé

1 Inleiding 1

1.1 Inleiding 1

1.2 Opzet van het rapport 3

2 Achtergrond van apothekersassistenten 5

2.1 Inleiding 5

2.2 Geslacht en leeftijd 5

$\begin{array}{lll}2.3 & \text { Gezinssituatie en reistijd } & 7\end{array}$

2.4 Werkervaring 9

$\begin{array}{ll}2.5 \text { Schoolverlaters en herintreders } & 10\end{array}$

3 Ontwikkelingen in het werk 13

3.1 Inleiding 13

3.2 Werkomstandigheden 13

3.3 Veranderingen in het werk 18

$\begin{array}{ll}3.4 \text { Tevredenheid met het werk } & 20\end{array}$

4 Competentieontwikkeling $\quad 25$

$\begin{array}{ll}4.1 \text { Inleiding } & 25\end{array}$

4.2 Competenties 25

4.3 Participatie in cursussen $\quad 28$

$\begin{array}{lll}4.4 & \text { Cursusparticipatie en competentieniveau } & 35\end{array}$

$5 \quad$ Flexibele inzetbaarheid en arbeidsmarktperspectieven 37

$\begin{array}{ll}5.1 \text { Inleiding } & 37\end{array}$

$\begin{array}{ll}5.2 \text { Overwerk } & 38\end{array}$

$\begin{array}{ll}5.3 \text { Taken en werkzaamheden } & 40\end{array}$

5.4 Loopbaan- en arbeidsmarktperspectieven 44

6 Effecten van scholing, flexibiliteit en brede inzetbaarheid 51

6.1 Inleiding 51

6.2 Effecten op salaris 52

6.3 Effecten op werkdruk en ziekteverzuim 54

6.4 Effecten op tevredenheid met werk 57

6.5 Effecten op loopbaan- en arbeidsmarktperspectieven 58

Bijlage A: De enquête 63

$\begin{array}{ll}\text { Bijlage B: Vragenlijst } & 65\end{array}$ 



\section{Voorwoord}

Dit rapport vormt één van de onderdelen van de arbeidsmarktmonitor voor de openbare apotheek ${ }^{1}$, die het Researchcentrum voor Onderwijs en Arbeidsmarkt (ROA) uitvoert in opdracht van de Stichting Bedrijfsfonds Apotheken (SBA). De arbeidsmarktmonitor bestaat, naast de enquête onder werkende apothekersassistenten waarvan in dit rapport verslag gedaan wordt, uit de monitoring van werkgevers in de openbare apotheek ${ }^{2}$, schoolverlaters van de opleiding voor apothekersassistent, en gediplomeerde apothekersassistenten die voorheen in de openbare apotheek hebben gewerkt. ${ }^{3}$ Bovendien zal er in het kader van de arbeidsmarktmonitor een toekomstverkenning van de mogelijke ontwikkelingen op de arbeidsmarkt voor apothekersassistenten gepubliceerd worden. Beleidsmakers, opleidinginstituten, werkgevers en werknemers kunnen op deze wijze beschikken over relevante informatie omtrent verschillende aspecten van het werken in de apothekersbranche en de huidige en toekomstige arbeidsmarktsituatie van apothekersassistenten.

Bij het tot stand komen van dit rapport zijn we dank verschuldigd aan dhr. M. van Aken van het Pensioenfonds Medewerkers Apotheken (PMA) voor het ter beschikking stellen van het steekproefbestand, dhr. L. Schreurs en mevr. J. Stijlen van het bureau Intomart voor de coördinatie van het veldwerk, mevr. G. Stauer en twee apothekersassistenten van de Emma Apotheek te Nijmegen voor de medewerking aan een proefenquête en dhr. F. Baart van de Stichting Farmaceutische Kengetallen (SFK) voor het samenstellen van een geanonimiseerd bestand op basis van de apothekersassistentengegevens en de apotheekgegevens. Ten slotte bedanken we dhr. S.J.C. van de Ven en dhr. J. Sax van der Weijden van de Stichting Bedrijfsfonds Apotheken (SBA) voor hun inbreng bij de samenstelling van de vragenlijst en de beschrijving van de onderzoeksresultaten in dit rapport.

1. Zie: F. Cörvers en A. de Grip (2001). Vooronderzoek arbeidsmarktmonitor apothekersbranche. ROA, Maastricht.

2. A. de Grip, J. Sanders en I. Sieben (2002). Knelpunten op de arbeidsmarkt en personeelsbeleid in de openbare apotheek. ROA-R-2002/10, Maastricht.

3. F. Cörvers, B.J. Diephuis en B. Golsteyn (2002). Het onbenutte arbeidspotentieel van apothekersassistenten voor de openbare apotheek, ROA-R-2002/2, Maastricht. 



\section{Resumé}

In dit rapport wordt verslag gedaan van een onderzoek naar het werken in de openbare apotheek, waartoe in november en december 2001 ruim 3.200 apothekersassistenten via een schriftelijke enquête ondervraagd zijn. Het rapport vormt één van de onderdelen van de Arbeidsmarktmonitor Apothekersbranche, die het Researchcentrum voor Onderwijs en Arbeidsmarkt (ROA) in opdracht van de Stichting Bedrijfsfonds Apotheken (SBA) uitvoert.

Het onderzoek beschrijft allereerst de verschillende aspecten van het werken in de openbare apotheek. Er wordt antwoord gegeven op de volgende vragen:

- Wat is de achtergrond van apothekersassistenten die werkzaam zijn in de openbare apotheek?

- Welke ontwikkelingen doen zich voor in het werk van deze assistenten? Daarnaast wordt inzicht gegeven in wat kan worden aangeduid als de employability van apothekersassistenten: het vermogen van mensen om werk te krijgen en werk te houden. Vragen die hiermee samenhangen zijn:

- In hoeverre ontwikkelen apothekersassistenten hun competenties door het volgen van scholing?

- In hoeverre worden apothekersassistenten flexibel en breed ingezet wat uren en taken betreft en wat zijn hun loopbaan- en arbeidsmarktperspectieven?

Ten slotte worden in het rapport de effecten van deze employability van apothekersassistenten op een aantal belangrijke terreinen in de openbare apotheek beschreven. Het gaat dan om de effecten van scholing, flexibiliteit en brede inzetbaarheid op het salaris van apothekersassistenten, de werkdruk en het ziekteverzuim, de tevredenheid van assistenten met hun werk en hun loopbaan- en arbeidsmarktperspectieven.

\section{Hoofdstuk 2 Achtergrond van apothekersassistenten}

Het beroep van apothekersassistent is een echt vrouwenberoep: slechts één op de honderd assistenten in de openbare apotheek is een man. De gemiddelde leeftijd van apothekersassistenten is 36 jaar. Apothekersassistenten in de Randstad (de regio's Noordwest en Middenwest) zijn gemiddeld wat ouder dan in de rest van Nederland. In de regio's Noord en Oost Nederland zijn de apothekersassistenten daarentegen relatief jong.

Ongeveer de helft van de assistenten heeft een partner en één of meer, veelal jonge, thuiswonende kinderen. De meeste apothekersassistenten wonen redelijk dicht bij de apotheek waar ze werkzaam zijn. De gemiddelde reistijd van huis naar werk is 18 minuten. Assistenten met kinderen (met name in de leeftijd 3-10 jaar) hebben een kortere reistijd. Kennelijk zoekt deze laatste groep, waarschijnlijk in verband met de schooltijden van hun kinderen, hun werk dichter bij huis. 


\section{Werkervaring}

De assistenten hebben gemiddeld genomen 13 jaar werkervaring als apothekersassistent, waarvan 8 jaar werkervaring in de huidige apotheek. 43\% Van de assistenten werkt minder dan 5 jaar in de apotheek waar men nu werkzaam is. Hoewel veel apothekersassistenten dus al geruime tijd bij hun huidige werkgever werken, blijken wisselingen van werkgever ook voor te komen. Ten slotte blijkt dat apothekersassistenten in de regio Zuidoost Nederland gemiddeld genomen langer bij de huidige apotheek in dienst zijn (9 jaar). Kennelijk is de honkvastheid in deze regio wat groter dan in de rest van het land.

\section{Herintreders}

Van alle apothekersassistenten die werkzaam zijn in de openbare apotheek is $16 \%$ herintreder. In de Randstad zijn beduidend meer herintreders in dienst dan in de andere regio's. Dit verklaart waarschijnlijk waarom de gemiddelde leeftijd van apothekersassistenten in deze regio's wat hoger ligt. Herintredende apothekersassistenten zijn immers wat ouder (gemiddeld zo'n 45 jaar) dan andere apothekersassistenten. Dat apothekers in de Randstad meer herintreders in dienst nemen, heeft mogelijk te maken met de grote knelpunten in de personeelsvoorziening die zij ervaren. Wellicht proberen zij door het aannemen van meer herintreders deze problemen de baas te worden.

Als belangrijkste reden om weer als apothekersassistent te gaan werken geven herintreders aan dat ze terug in het vak wilden. Het beroep van apothekersassistent oefent dus een grote aantrekkingskracht op herintreders uit. Opvallend is verder dat iets meer dan een kwart van de herintreders gevraagd is door een oud-collega of vriendin. Dit duidt erop dat dit informele netwerk een belangrijke rol speelt bij het overhalen van herintreders om terug te keren in de openbare apotheek. Als positieve overwegingen bij de keuze om weer te gaan werken worden door veel herintreders de mogelijkheid tot deeltijdwerk, het combineren van werk en zorgtaken en de werksfeer genoemd. De onregelmatige diensten die bij het vak van apothekersassistent horen worden als negatief beschouwd. Daarnaast worden de salariëring en de loopbaanperspectieven van assistenten als negatieve overwegingen genoemd.

\section{Hoofdstuk 3 Ontwikkelingen in het werk}

Apothekersassistenten werken gemiddeld 26,7 uur per week. Het aantal werkuren per week hangt sterk samen met de gezinssituatie. Assistenten met kinderen werken bijna allemaal in deeltijd. Vooral wanneer er jonge kinderen zijn, is het aantal uren dat men werkt gering. Ongeveer de helft van de apothekersassistenten met kinderen jonger dan 10 jaar werkt minder dan 20 uur per week. Ook herintreders hebben vaak (kleine) deeltijdbanen. Slechts $12 \%$ van hen werkt 32 uur per week of meer. 


\section{Werkdruk}

De werkdruk in de openbare apotheek is vrij hoog. Met name het werken onder een hoge tijdsdruk blijkt veelvuldig in de openbare apotheek voor te komen. Een aanzienlijk deel van de assistenten vindt het werk regelmatig geestelijk zwaar, en één vijfde geeft aan regelmatig onder slechte fysieke omstandigheden te werken. Daarentegen vindt slechts $6 \%$ van de assistenten dat ze regelmatig eentonig werk verrichten. Apothekersassistenten in de regio's Noordwest, Middenwest en Zuidwest Nederland ervaren vaker een hoge tijdsdruk, lichamelijk zwaar werk en slechte fysieke arbeidsomstandigheden dan assistenten in de regio's Noord en Oost Nederland.

\section{Ziekteverzuim}

Gemiddeld genomen verzuimden apothekersassistenten in 2001 9,5 werkdagen ziek. Ongeveer de helft van de assistenten was in 2001 geen enkele dag ziek. De oorzaak van het ziekteverzuim lag in $2 \%$ van de gevallen geheel en in $7 \%$ gedeeltelijk bij het werk. Werkgerelateerd ziekteverzuim blijkt echter wel langer te duren. Zo verzuimen assistenten die aangeven dat de oorzaak van hun ziekzijn geheel bij het werk te vinden is, gemiddeld maar liefst 50,5 dagen. Wanneer de oorzaak van het ziekteverzuim gedeeltelijk bij het werk ligt, dan is het gemiddelde 31,2 dagen. Uit deze cijfers kan worden afgeleid dat ruim $17 \%$ van het totale ziekteverzuim geheel of gedeeltelijk samenhangt met het werk. Als dit verlies met de helft zou kunnen worden teruggedrongen, dan staat dit gelijk aan een extra arbeidspotentieel van circa 70 fulltime werkende apothekersassistenten per jaar. Deze cijfers benadrukken nogmaals de noodzaak om het werkgerelateerde ziekteverzuim in de openbare apotheek - waar mogelijk - terug te dringen.

\section{Veranderingen in het werk}

Assistenten noemen als de belangrijkste veranderingen in het werk de mondigheid van cliënten, de intensievere patiëntenvoorlichting, minder bereidingen, klantgerichtheid en verhoging van de werklast. Een aanzienlijk deel van hen geeft aan moeite te hebben met het aanpassen aan deze veranderingen. Over het algemeen vinden oudere werknemers, assistenten met veel werkervaring en herintreders het moeilijker om zich aan te passen. Schoolverlaters hebben daarentegen minder moeite met de genoemde veranderingen. Dit houdt waarschijnlijk verband met de grotere flexibiliteit van jonge werknemers. Ook zou er sprake kunnen zijn van het tekortschieten van bepaalde competenties bij assistenten die lang geleden van school zijn gegaan. Zo scoren herintreders en assistenten met meer werkervaring beduidend lager op communicatieve vaardigheden. Deze vaardigheden worden in het werk steeds belangrijker omdat het contact met de cliënt toeneemt. Het belangrijkste probleem bij het aanpassen aan de veranderingen in de openbare apotheek is overigens tijdgebrek. Daarna volgen een gebrekkige communicatie met de leidinggevende apotheker en te weinig begeleiding. Met name herintreders vinden dit laatste een belangrijk probleem. 


\section{Tevredenheid}

Het overgrote deel van de apothekersassistenten is (zeer) tevreden met hun huidige baan. Assistenten zijn met name over de zelfstandigheid, de werktijden, de inhoud van het werk en de werksfeer zeer te spreken. Wat minder tevreden zijn ze over de wijze van leidinggeven door de apotheker en de werkdruk. Over de loopbaanperspectieven en het salaris is men het minst tevreden. De kleine groep apothekersassistenten die een tijdelijk contract heeft, is duidelijk minder tevreden met hun werk, met name wat betreft de zelfstandigheid, de inhoud van het werk, de werksfeer en de scholingsfaciliteiten. Wellicht wordt deze groep (tijdelijk) door apothekers ingeschakeld om de grote pieken op te vangen en moeten zij daarom het minst leuke en het minst uitdagende werk verrichten. Voor het imago van het werken in de openbare apotheek is dit waarschijnlijk geen goede zaak.

Het personeels- en arbeidsvoorwaardenbeleid in de openbare apotheek wordt ook als vrij positief ervaren. Werkoverleg en functioneringsgesprekken vinden op grote schaal plaats. (Zeer) tevreden zijn assistenten over het spaarloon, de flexibele werktijden, de reiskostenvergoeding en het extra kleedgeld. Minder tevreden zijn zij over de beloning voor het succesvol afronden van een cursus en over de prestatiebeloning. Opvallend is dat naarmate men meer werkervaring heeft, men minder tevreden is over het personeelsbeleid in de openbare apotheek. Wellicht is het voor apothekers moeilijk om jaren achtereen de dynamiek in het personeelsbeleid te houden en dit steeds aan te passen aan de in de tijd veranderende wensen van de assistenten.

\section{Hoofdstuk 4 Competentieontwikkeling}

Assistenten scoren een dikke voldoende wat hun kennis en vaardigheden betreft. Dat blijkt niet alleen uit de manier waarop zij hun eigen competenties beoordelen, maar ook uit de cijfers die de apothekers aan hun apothekersassistenten gaven. Schoolverlaters schatten hun competenties als 'communicatieve vaardigheden en omgangskunde', 'zelfstandigheid' en 'omgaan met verantwoordelijkheid' wat minder hoog in. Aangenomen mag worden dat deze kennis en vaardigheden moeilijker op school aangeleerd kunnen worden en dat zij tijdens het werken verder ontwikkeld moeten worden. Schoolverlaters zijn echter beduidend beter in 'computervaardigheden' dan de andere assistenten. Herintreders en assistenten met meer werkervaring scoren op bijna alle competenties wat lager. Met name op het terrein van 'communicatieve vaardigheden en omgangskunde' en 'het bereiden van geneesmiddelen' vallen hun rapportcijfers duidelijk lager uit. Dit duidt op een zekere mate van kwalificatieveroudering. Wellicht was er minder aandacht voor deze aspecten toen zij hun opleiding volgden.

Volgens de meeste assistenten kunnen competenties als 'communicatieve vaardigheden', 'computervaardigheden' en 'bereiden van geneesmiddelen' het beste op peil gehouden worden via het leren op de werkplek. Geneesmiddelenkennis kan daarentegen beter door het volgen van cursussen op niveau gehouden worden. Het leren op de werkplek speelt hierbij een beduidend kleinere rol. Opvallend is dat schoolver- 
laters vaker dan andere assistenten aangeven dat het leren van collega's de beste manier is om hun competenties op peil te houden.

\section{Cursusparticipatie}

64\% Van de apothekersassistenten in de openbare apotheek heeft in 2001 één of meerdere cursussen gevolgd. Schoolverlaters participeren wat vaker in cursussen, terwijl herintreders opmerkelijk genoeg wat minder vaak cursussen volgen. Verder blijken fulltime werkende assistenten veel vaker deel te nemen aan cursussen dan parttimers. Ten slotte zijn er enkele opvallende regionale verschillen. Maar liefst $76 \%$ van de apothekersassistenten in de regio Noord Nederland heeft in 2001 een cursus gevolgd, tegenover slechts $54 \%$ in de regio Zuidoost.

Sectorspecifieke cursussen als 'kennis van ziektebeelden' en 'geneesmiddelenkennis' zijn het meest populair. Het is opvallend dat deze cursussen minder vaak gevolgd worden door oudere werknemers, assistenten met meer werkervaring en herintreders. De participatie van apothekersassistenten in cursussen van meer algemene aard is veel minder groot dan de deelname aan sectorspecifieke cursussen. Hier zijn cursussen op het terrein van de communicatieve vaardigheden het meest populair (12\%). Deze cursussen worden door schoolverlaters overigens veel vaker gevolgd dan door andere assistenten.

Volgens de apothekersassistenten is de belangrijkste reden om een cursus te volgen bij te blijven in het vakgebied. Daarnaast worden het zich verder specialiseren en het wegwerken van een specifiek tekort aan kennis en vaardigheden vaak als reden opgegeven. Opvallend is ook dat voor $13 \%$ van de assistenten de aan de cursus gekoppelde salarisverhoging een belangrijke reden is om een cursus te volgen.

\section{Cursussen en competentieniveau}

Kunnen apothekersassistenten hun competenties nu verbeteren door cursussen te volgen? Met name de sectorspecifieke kennis en vaardigheden van assistenten, zoals de informatieverstrekking over geneesmiddelen, het recepteren en bereiden van geneesmiddelen en kennis van ziektebeelden, blijken beter te worden door aan cursussen op dat terrein deel te nemen. De enige uitzondering is het niveau van de competentie 'recepteren van geneesmiddelen'. Dit competentieniveau verschilt niet tussen degenen die een cursus op dat gebied gevolgd hebben en degenen die dat niet gedaan hebben. Hetzelfde geldt voor de cursussen gericht op het verbeteren van algemene competenties als communicatieve vaardigheden, zelfstandigheid en omgaan met verantwoordelijkheid. Wel kunnen door het volgen van een cursus computervaardigheden de competenties van assistenten op dit gebied worden opgekrikt.

Overigens geeft een ruime meerderheid van de assistenten aan de opgedane kennis bij de eigen werkzaamheden te gebruiken. Nog eens een aanzienlijk deel zegt dat de kennis zowel door henzelf als door collega's in de apotheek toegepast wordt. Slechts $5 \%$ van de assistenten die in 2001 een cursus gevolgd hebben laat weten dat de 
opgedane kennis niet van pas komt in het werk. Opvallend hierbij is dat de cursussen 'recepteren van geneesmiddelen' en 'bereiden van geneesmiddelen' als de minst nuttige cursussen beschouwd worden.

\section{Hoofdstuk 5 Flexibele inzetbaarheid en arbeidsmarktperspectieven}

Naast scholing is flexibele inzetbaarheid een tweede instrument om de employability van apothekersassistenten in de openbare apotheek te vergroten. Flexibele inzetbaarheid wordt gekenmerkt door een kwantitatieve dimensie (het aantal werkuren) en een kwalitatieve dimensie (het verrichten van taken die niet tot de functie behoren).

\section{Overwerk}

Driekwart van de apothekersassistenten in de openbare apotheek houdt zich aan het aantal werkuren dat in hun contract afgesproken is. $13 \%$ Van de apothekersassistenten werkt meer uren dan in hun contract staat. Gemiddeld gaat het om zo'n 3 uur per week. Apothekersassistenten met jonge kinderen werken minder vaak over, wellicht omdat zij hun tijd buiten het werk willen besteden aan zorgtaken. Assistenten met kinderen in de leeftijd van 5 tot 15 jaar werken echter juist vaker over dan andere assistenten. Mogelijk slagen assistenten met schoolgaande kinderen er beter in om werk en zorgtaken te combineren, waardoor zij in staat zijn om meer uren buiten hun contract te werken. Waarschijnlijk spelen bovendien financiële motieven een rol bij de beslissing om overwerk te verrichten. Ten slotte blijken ook assistenten die minder dan 20 uur per week werken vaker over te werken. Wellicht maken kleine deeltijdbanen het makkelijker voor assistenten om een paar uur extra te werken.

Opvallend is verder dat assistenten die al overwerken een grotere bereidheid tonen om meer uren te werken. Dit zou erop kunnen duiden dat het overwerken hen goed bevalt. $6 \%$ Van alle apothekersassistenten zou meer uren willen werken dan zij nu doen. Gemiddeld gaat het om zo'n 5 uur extra werk per week. Assistenten die nu al overwerken zijn sterk oververtegenwoordigd in deze groep.

\section{Taken en werkzaamheden}

Het grootste deel van de werkweek van assistenten wordt gevuld met basistaken als standaard baliecontacten, medicijnen dispenseren en medicatiebewaking. De farmaceutische patiëntenzorg vormt slechts een klein deel van het takenpakket van apothekersassistenten. Met administratieve handelingen als het afhandelen en opbergen van recepten en nota's voor patiënten zijn apothekersassistenten in de openbare apotheek gemiddeld slechts zeer weinig tijd kwijt.

Het is opvallend dat herintreders vaker bezig zijn met wat eigenlijk de basistaken van een apothekersassistent zijn: standaard baliecontacten, medicijnen bereiden en dispenseren. Ook de in deeltijd werkende assistenten worden relatief vaak ingezet bij deze basistaken. Verder blijken assistenten met een hoge competentiescore zich 
vaak bezig te houden met de medicatiebewaking en de farmaceutische patiëntenzorg. Assistenten met minder competenties verrichten vaker basistaken als medicijnen dispenseren en besteltaken. Dit duidt erop dat sommige werkzaamheden een hoger algemeen of sectorspecifiek competentieniveau vereisen dan andere werkzaamheden en dat er in de openbare apotheek gezocht wordt naar het inzetten van de juiste assistenten voor deze werkzaamheden.

Overigens vinden apothekersassistenten in de openbare apotheek de basistaken de kern van het beroep - het plezierigst. Het feit dat met name herintreders en parttimers deze taken uitvoeren, betekent dat zij niet met de minst leuke klussen opgescheept worden. Dit zal hun binding met de apotheek waar ze werkzaam zijn versterken. Ook het verzorgen van de farmaceutische patiëntenzorg vinden veel assistenten een plezierige werkzaamheid, gevolgd door de bereiding van medicijnen. Taken op het gebied van de financiën en de administratie wordt duidelijk minder vaak als plezierig ervaren.

\section{Brede inzetbaarheid}

Eén op de drie assistenten verricht wel eens taken die niet tot hun functie behoren. $6 \%$ Neemt farmaceutische taken van de apotheker over; $13 \%$ voert wel eens management taken uit zoals het doen van de administratie en personeelszaken. Eén op de zes apothekersassistenten verricht wel eens taken uit andere functies.

Schoolverlaters en herintreders worden veel minder breed ingezet dan andere apothekersassistenten, net als de in deeltijd werkende apothekersassistenten. Opvallend is verder dat assistenten in de Randstad vaker taken uit andere functies uitvoeren. Dit wijst erop dat apothekers door het breed inzetten van apothekersassistenten proberen de nadelige gevolgen van de personeelstekorten die in deze regio spelen te verminderen.

\section{Loopbaan- en arbeidsmarktperspectieven}

Zeven van de tien apothekersassistenten denkt over 5 jaar nog als apothekersassistent in de huidige apotheek te werken. Deze assistenten zijn vaker werkzaam in de grotere apotheken. Blijkbaar zijn deze apotheken aantrekkelijk om in te werken. Daarnaast werken de 'honkvaste' assistenten beduidend vaker in apotheken in de regio's Oost en Zuidoost Nederland. Verder blijkt dat de intentie om van werkgever of functie te veranderen kleiner is wanneer men eenmaal een aantal jaren als apothekersassistent aan het werk is. Enerzijds heeft men dan waarschijnlijk de baan gevonden die men het meest aantrekkelijk vindt. Anderzijds hebben werknemers met veel werkervaring vaak te kampen met zogenaamde ervaringsconcentratie. Wanneer werknemers lange tijd dezelfde functie binnen dezelfde organisatie vervullen, dan zijn hun competenties wellicht te specifiek geworden, waardoor hun inzetbaarheid in andere organisaties afneemt.

Van de assistenten die aangeven over 5 jaar niet meer als apothekersassistent te werken, denkt een groot deel dan ander werk te verrichten, een ander deel verwacht 
gestopt te zijn met werken. Deze laatste groep bestaat voornamelijk uit werknemers die ouder zijn dan 50 jaar. Daarnaast verwacht bijna één op de tien assistenten over 5 jaar wel nog als apothekersassistent te werken, maar dan in een andere apotheek of buiten de openbare apotheek.

\section{Redenen voor vertrek}

Assistenten die verwachten als apothekersassistent in een andere openbare apotheek aan de slag te gaan, noemen met name de werksfeer en de te hoge werkdruk als reden om elders te gaan werken. Ook een te lange reistijd en een te verwachte verhuizing spelen een rol bij de verwachting dat men de komende jaren van werkgever zal wisselen. Dit bevestigt nogmaals het beeld dat apothekersassistenten het liefst dichtbij hun werk willen wonen. Daarnaast denkt één op de vijf assistenten die denkt te vertrekken in een andere openbare apotheek meer te kunnen verdienen.

Het hogere salaris dat men elders verwacht te kunnen verdienen is tevens de belangrijkste reden om over 5 jaar als apothekersassistent buiten de openbare apotheek te gaan werken. Ook denkt een groot deel van deze assistenten dat de loopbaanperspectieven buiten de openbare apotheek beter zijn. De te hoge werkdruk en het niet bevredigend zijn van het soort werk dat men momenteel doet wordt door éénderde van de apothekersassistenten die buiten de openbare apotheek denkt te gaan werken genoemd als een reden voor vertrek.

Ook assistenten die verwachten over 5 jaar een andere baan dan apothekersassistent te hebben, geven als belangrijkste reden op dat zij denken elders een hoger salaris te kunnen verdienen. Dit duidt erop dat er iets met de salariëring dient te gebeuren, wil men deze apothekersassistenten voor de openbare apotheek behouden. Dit proces is al gedeeltelijk in gang gezet door het in 2003 in te voeren systeem van functiewaardering en de bijbehorende salarisverhoging. Verder noemen assistenten die in de toekomst ander werk willen verrichten als reden dat het huidige werk niet bevredigend is, de werkdruk te hoog en de werksfeer niet goed is.

Eén op de tien apothekersassistenten in de openbare apotheek is overigens daadwerkelijk op zoek naar een andere baan. De meeste van deze assistenten willen graag een baan in een andere functie. Zo zoekt $4 \%$ van alle apothekersassistenten naar een andere functie binnen de apothekersbranche en wil $5 \%$ een andere functie buiten de sector. 1\% Van de assistenten is op zoek naar een baan als apothekersassistent buiten de openbare apotheek.

\section{Perspectieven binnen en buiten de sector}

De meeste apothekersassistenten zien hun arbeidsmarktperspectieven binnen de sector rooskleurig in. $62 \%$ Van de assistenten denkt dat het (zeer) gemakkelijk is om een minstens even aantrekkelijke baan elders binnen de branche te vinden. Het vinden van een baan buiten de sector wordt als moeilijker beschouwd. Slechts één op de vijf apothekersassistenten denkt dat het (zeer) gemakkelijk is om een minstens even aantrekkelijke baan buiten de sector te vinden. 
Met name apothekersassistenten met veel werkervaring denken dat het voor hen moeilijk is om binnen of buiten de branche een minstens even aantrekkelijke baan te vinden. Dit heeft waarschijnlijk te maken met wat we eerder beschreven als hun ervaringsconcentratie. Assistenten die al lang hun functie uitoefenen, beschikken doorgaans over sectorspecifieke en bedrijfsspecifieke kennis en vaardigheden. Dit maakt het moeilijker om elders in een meer aantrekkelijke baan aan de slag te kunnen gaan. Het is in dit opzicht dan ook niet verwonderlijk dat apothekersassistenten die in een andere functie werkervaring opgedaan hebben, het vinden van een minstens even aantrekkelijke baan buiten de branche vaker als gemakkelijk inschatten.

Verder blijken er op dit punt enkele regionale verschillen te bestaan. Zo schatten assistenten in de Randstad hun arbeidsmarktperspectieven binnen en buiten de branche gunstiger in dan elders in Nederland. Deze betere arbeidsmarktperspectieven hangen duidelijk samen met de grote personeelstekorten in de Randstad. In de regio Oost Nederland daarentegen is het - volgens de assistenten - minder gemakkelijk om binnen of buiten de branche een even aantrekkelijke andere baan te vinden. Assistenten in de regio Noord Nederland ten slotte beoordelen de arbeidsmarktperspectieven binnen de branche als gunstiger, maar buiten de branche als ongunstiger.

\section{Hoofdstuk 6 Effecten van scholing, flexibiliteit en brede inzetbaarheid}

Naast het beschrijven van de employability van apothekersassistenten, is het zeer interessant om de effecten hiervan op een aantal belangrijke terreinen na te gaan. $\mathrm{Bij}$ het bepalen van de effecten van scholing, flexibiliteit en brede inzetbaarheid baseren we ons op de verbanden die we vinden tussen de antwoorden op de verschillende vragen die we aan de apothekersassistenten en apothekers gesteld hebben. Een dergelijke statistische analyse heeft als groot voordeel dat er onverwachte relaties gelegd kunnen worden die de discussie binnen de branche over een aantal belangrijke zaken kan bevorderen. Aan de andere kant zullen dergelijke uitkomsten nieuwe vragen opwerpen of de wens oproepen door het stellen van meer of betere vragen de gevonden effecten beter te onderzoeken.

\section{Effecten op salaris}

Zoals verwacht, wordt het salaris van apothekersassistenten in de openbare apotheek met name bepaald door hun werkervaring. Hierbij telt echter niet alleen de werkervaring als apothekersassistent, maar ook de werkervaring die men elders heeft opgedaan mee. Er is geen sprake van een regio-opslag: apothekersassistenten die werkzaam zijn in regio's waar grote knelpunten op de arbeidsmarkt zijn, zoals bijvoorbeeld de Randstad, krijgen niet significant meer betaald dan assistenten in andere regio's.

Wat de employability van apothekersassistenten betreft, blijken apothekersassistenten die breed inzetbaar zijn, meer te verdienen. Zo krijgen assistenten die manage- 
menttaken uitvoeren een hoger salaris, net als assistenten die vaker werkzaamheden als standaard baliecontacten, bereiding van medicijnen, administratie en overige taken als etalagebeheer en bezorgen uitvoeren. Het volgen van cursussen blijkt het salaris van apothekersassistenten niet te beï nvloeden. Hierbij moet echter wel opgemerkt worden dat het hierbij alleen gaat om cursussen die de assistenten het afgelopen jaar gevolgd hebben. Om in aanmerking te komen voor de in de CAO vastgestelde salarisverhoging, dienen assistenten 120 studiepunten te verzamelen. Aangezien een cursus gemiddeld 21 studiepunten oplevert, moeten er heel wat cursussen gevolgd worden om voor deze salarisverhoging in aanmerking te komen. Wel is het zo dat apothekersassistenten met een hogere score voor hun sectorspecifieke competenties meer betaald krijgen. Deze competenties hebben ook een directe relatie met het werk als apothekersassistent (bijvoorbeeld het bereiden van medicijnen). Apothekersassistenten met een hogere score op hun algemene competenties worden daarentegen niet hoger beloond.

\section{Effecten op de werkdruk en het ziekteverzuim}

Het uitvoeren van managementtaken door apothekersassistenten leidt tot een hogere werkdruk. Het verrichten van andere taken die niet tot hun functie behoren heeft daarentegen geen invloed op de werkdruk, of zorgt zelfs voor een lagere werkdruk zoals bij assistenten die vaker de administratie doen. Verder is het opmerkelijk dat overwerk niet tot een hogere werkdruk leidt. Wellicht heeft dit te maken met het feit dat de meeste apothekersassistenten die overwerken dit vrijwillig en graag doen. Aangezien veel overwerk in de openbare apotheek bestaat uit het draaien van extra diensten op zaterdag volgens een vast patroon, zal dit weinig belasting voor de assistenten opleveren. Daarnaast is het mogelijk dat overwerk ertoe leidt dat de werkdruk in de openbare apotheek tijdens de normale werktijden afneemt.

Apothekersassistenten die te maken hebben met prestatiebeloning ervaren wel een hogere werkdruk. Misschien voelen zij zich meer opgejaagd dan assistenten die niet met deze vorm van beloning te maken hebben. Verder hebben apothekersassistenten met kleine kinderen en herintreders met een hogere werkdruk te kampen. Wellicht betekent dit dat deze laatste twee groepen assistenten het moeilijk vinden om werk en zorgtaken te combineren.

Apothekersassistenten die beter scoren op algemene competenties als communicatieve vaardigheden, zelfstandigheid, omgaan met verantwoordelijkheid en omgaan met collega's ervaren een lagere werkdruk. Deze grotere vaardigheden stellen hen kennelijk in staat hun werk effectiever te verrichten en op plezierige wijze met klanten en collega's om te gaan. Een HRM beleid dat zich richt op het verbeteren van de algemene competenties van apothekersassistenten zal overigens niet direct de ervaren werkdruk verminderen. Het blijkt immers dat het volgen van cursussen geen invloed heeft op de werkdruk die apothekersassistenten in de openbare apotheek ervaren. Een mogelijke verklaring hiervoor is dat cursussen op de korte termijn voornamelijk tijd en energie kosten. Dit zou het eventuele positieve effect van deze cursussen op de werkdruk, namelijk het vergroten van de competenties van assistenten en daardoor het vergroten van hun efficiëntie, wellicht teniet kunnen doen. 
Een hoge werkdruk zorgt ervoor dat het ziekteverzuim in de apotheek toeneemt. Ook het regelmatig geestelijk zwaar werk moeten verrichten en met slechte fysieke omstandigheden te maken hebben leiden tot een hoger ziekteverzuim onder apothekersassistenten. Verder blijken assistenten met minder werkervaring langduriger ziek te zijn. Ten slotte is het opvallend dat het aanbieden van aanvullingen op de kinderopvangregeling CAO het langdurig ziekteverzuim terug kan dringen. Dit betekent dat apothekers kunnen inspelen op ziekteverzuim dat mede veroorzaakt wordt door de problemen die assistenten ondervinden bij het combineren van werk en zorgtaken.

\section{Effecten op de tevredenheid met het werk}

Apothekersassistenten die regelmatig met eentonig werk te maken hebben, zijn minder tevreden. Ook het regelmatig onder hoge tijdsdruk werken leidt tot minder tevredenheid met het werk. Opvallend is dat de andere arbeidsomstandigheden als het verrichten van lichamelijk of geestelijk zwaar werk en het onder slechte fysieke omstandigheden werken de tevredenheid van apothekersassistenten niet beï nvloeden. Wel zijn assistenten die met prestatiebeloning te maken hebben, ontevredener over hun werk. Deze vorm van beloning is duidelijk niet populair onder apothekersassistenten

Ten slotte blijkt dat ook apothekersassistenten die overwerken over het algemeen minder tevreden te zijn. Dit is opmerkelijk, aangezien de meeste apothekersassistenten vrijwillig en graag overwerken en zelfs bereid zijn om nog meer uren over te werken. Wellicht zijn zij wel tevreden met hun overwerk, maar ontevreden over de te geringe omvang van hun aanstelling of over andere aspecten van hun werk als apothekersassistent. Ook assistenten die breed inzetbaar zijn - in die zin dat zij farmaceutische taken van de apotheker uitvoeren - zijn minder tevreden.

\section{Effecten op loopbaan- en arbeidsmarktperspectieven}

Apothekersassistenten die vaker werkzaamheden uitvoeren die tot de basistaken van hun functie behoren, zoals standaard baliecontacten en medicijnen dispenseren, denken dat het vrij gemakkelijk is om elders binnen de branche een minstens even aantrekkelijke baan te vinden. Hieruit zou geconcludeerd mogen worden dat de arbeidsmarktperspectieven van assistenten binnen de branche meer verbeteren door het goed uitoefenen van de werkzaamheden die tot de functie van apothekersassistent behoren dan door taken te verrichten die niet tot hun functie behoren. Het is dan ook opvallend dat het competentieniveau van apothekersassistenten, en dan met name op het gebied van de sectorspecifieke competenties, de arbeidsmarktperspectieven binnen de branche niet beï nvloeden. Dit zou overigens verklaard kunnen worden uit de eerdere constatering dat de assistenten met betere sectorspecifieke competenties zich al voldoende gewaardeerd voelen in hun huidige functie, zoals bleek uit het hogere salaris dat ze verdienen en hun grotere tevredenheid met hun huidige baan. lemands werkervaring als apothekersassistent blijkt overigens geen invloed te hebben op de arbeidsmarktperspectieven binnen de branche. 
Bij de arbeidsmarktperspectieven buiten de branche blijkt het competentieniveau van apothekersassistenten wel van belang. Hoe beter zij scoren op de algemene competenties, des te gemakkelijker denken zij een minstens even aantrekkelijke baan elders buiten de branche te vinden. Het is aannemelijk dat algemene competenties als communicatieve vaardigheden, zelfstandigheid, omgaan met verantwoordelijkheid en omgaan met collega's ook buiten de branche hun waarde op de arbeidsmarkt hebben. Flexibele of breed inzetbare apothekersassistenten schatten hun arbeidsmarktperspectieven buiten de branche niet beter of slechter in dan minder employabele assistenten.

Ten slotte blijkt dat apothekersassistenten die tevreden zijn met hun werk minder snel op zoek gaan naar een andere baan. Willen apothekers hun assistenten behouden, dan is het dus zaak om veel aandacht te hebben voor hun tevredenheid met het werk. Eerder bleek al met name het laten uitvoeren van farmaceutische taken van de apotheker, regelmatig eentonig werk verrichten en het regelmatig onder een hoge tijdsdruk werken een ongunstig effect hebben op de tevredenheid van de apothekersassistenten. Het regelmatig te maken hebben met lichamelijk zwaar werk is voor apothekersassistenten zelfs een directe reden om ander werk te gaan zoeken. Ook blijkt dat assistenten die vaker besteltaken en overige taken als etalagebeheer, schoonmaken en bezorgen uitvoeren eerder op zoek gaan naar een andere baan. Deze taken worden door assistenten ook als minder plezierig ervaren dan de basistaken. Een andere mogelijkheid voor apothekers die graag hun assistenten willen behouden is om hen flexibele werktijden aan te bieden. 


\section{Inleiding}

\subsection{Inleiding}

Op dit moment is er sprake van een groot tekort aan apothekersassistenten in de openbare apotheek. Deze krapte op de arbeidsmarkt voor apothekersassistenten zal de komende jaren naar verwachting nog toenemen, zo blijkt uit prognoses tot $2006 .{ }^{4}$ De zorg bestaat dat dit zijn weerslag heeft op het werken in de openbare apotheek. Doordat vacatures voor apothekersassistenten moeilijk op te vullen zijn, is het aannemelijk dat werkgevers in de farmaceutische zorg zullen proberen om apothekersassistenten flexibel in te zetten, bijvoorbeeld door hen meer uren te laten werken of door hen werkzaamheden te laten verrichten die niet tot hun functie behoren. Dit zou ertoe kunnen leiden dat de toch al niet geringe werkdruk in de openbare apotheek stijgt en dat apothekersassistenten in toenemende mate naar ander werk op zoek gaan. Aan de andere kant kan een goed personeelsbeleid de aantrekkingskracht van het beroep apothekersassistent vergroten. Goede werkomstandigheden in de openbare apotheek en het aanbieden van goede opleidings- en ontwikkelingsmogelijkheden zouden ervoor kunnen zorgen dat apothekers aantrekkelijke werkgevers zijn.

In dit rapport worden verschillende aspecten van het werken in de openbare apotheek in kaart gebracht. Daarnaast wordt er inzicht gegeven in wat kan worden aangeduid als de employability van apothekersassistenten. Employability wordt vaak kortweg gedefinieerd als het vermogen van mensen om werk te krijgen en werk te houden. ${ }^{5}$ De employability van apothekersassistenten is in de eerste plaats afhankelijk van hun competentieontwikkeling. Door scholing verbeteren assistenten hun competenties, waardoor ze beter in staat zijn hun functie adequaat uit te oefenen. Bovendien gaan ze op deze wijze kwalificatieveroudering tegen die kan optreden omdat het werk steeds nieuwe kennis en vaardigheden vereist. Zo versterken apothekersassistenten tevens hun arbeidsmarktpositie. Voor apothekers is het ook aantrekkelijk om te investeren in de scholing van hun werknemers, omdat dit de productiviteit kan verhogen en de kwaliteit van de dienstverlening kan verbeteren. Daarnaast kan scholing, als onderdeel van een goed personeelsbeleid, een middel zijn om assistenten aan de apotheek te binden. Naast het ontwikkelen van hun competenties, kan een flexibele houding ten aanzien van het aantal uren dat zij werken en het verrichten van taken die niet tot hun functie behoren de employability van apothekersassistenten vergroten. Assistenten die beter reageren en anticiperen op veranderingen in arbeidstaken en werkomgeving vergroten hun waarde voor de arbeidsmarkt - zowel binnen als buiten de apothekersbranche.

4. A. de Grip en J.D. Vlasblom (1999). Toekomstverkenning arbeidsmarkt apothekersassistenten in de openbare apotheek. ROA-R-1999/7, Maastricht.

5. A. de Grip (2000). Van tweedekansonderwijs naar een leven lang leren. De veranderende betekenis van post-initiële scholing. Inaugurele rede, Universiteit Maastricht, Maastricht. 
Voor apothekersassistenten, apothekers en beleidsmakers is het interessant om een goed beeld te hebben van de effecten van deze employability op een aantal belangrijke terreinen in de openbare apotheek. Daarbij kan gedacht worden aan de effecten van scholing, flexibiliteit en brede inzetbaarheid op het salaris van apothekersassistenten, de werkdruk en het ziekteverzuim, de tevredenheid van assistenten met hun werk en hun loopbaan- en arbeidsmarktperspectieven. Is het zo dat apothekersassistenten die cursussen volgen en zich flexibel opstellen, meer verdienen dan assistenten die dat niet doen? Hebben zij minder te kampen met een hoge werkdruk en ziekteverzuim en zijn zij meer tevreden met hun werk? En zijn hun loopbaan- en arbeidsmarktperspectieven zowel binnen als buiten de apothekersbranche beter?

Kortom, in dit rapport worden antwoorden geformuleerd op de volgende vragen:

- Wat is de achtergrond van apothekersassistenten werkzaam in de openbare apotheek?

- Welke ontwikkelingen doen zich voor in het werk van deze apothekersassistenten?

- In hoeverre ontwikkelen apothekersassistenten in de openbare apotheek hun competenties door het volgen van scholing?

- In hoeverre worden apothekersassistenten in de openbare apotheek flexibel en breed ingezet en wat zijn hun loopbaan- en arbeidsmarktperspectieven?

- Wat zijn de effecten van scholing, flexibiliteit en brede inzetbaarheid op het salaris van apothekersassistenten, de werkdruk, het ziekteverzuim, de tevredenheid met het werk en de loopbaan- en arbeidsmarktperspectieven binnen en buiten de apothekersbranche?

Om deze vragen te kunnen beantwoorden, is in november en december 2001 een enquête gehouden onder apothekersassistenten in de openbare apotheek. In totaal hebben 3.229 assistenten aan dit onderzoek meegewerkt. De opzet, respons en representativiteit van deze werknemersenquête zijn beschreven in bijlage A. De vragenlijst zelf is in bijlage $B$ te vinden.

In de verschillende hoofdstukken zullen we rekening houden met een aantal belangrijke kenmerken van openbare apotheken, zoals het soort apotheek (zelfstandige apotheek of een niet-zelfstandige apotheek uit een keten of maatschap), de omvang van de apotheek en de regio waarin de apotheek gevestigd is. Het is aannemelijk dat deze factoren het werken in de openbare apotheek beï nvloeden. ${ }^{6}$ De apotheekkenmerken zijn bevraagd in een werkgeversenquête onder apothekers en anoniem aan de werknemersenquête gekoppeld. Op deze wijze beschikken we voor één op de drie deelnemende apothekersassistenten over relevante apotheekkenmerken. ${ }^{7}$ Daar

6. In het rapport zullen we telkens alleen de statistiek significante verschillen vermelden.

7. Het is niet mogelijk gebleken om de gegevens van alle deelnemende apothekersassistenten te koppelen aan de gegevens uit het werkgeversbestand. In de eerste plaats heeft dit te maken met de manier waarop de koppeling plaatsvond, namelijk via de postcode van de werkgever. Niet alle apothekersassistenten wilden deze postcode doorgeven; daarnaast vulden een aantal een onvolledige of niet bestaande postcode in (totaal: 11\%). In de tweede plaats hebben niet alle apothekers deelgenomen aan de werkgeversenquête. De respons van deze enquête bedroeg $42 \%$. 
naast zullen we in dit rapport waar mogelijk de uitkomsten van de werknemersenquête vergelijken met de resultaten van het werkgeversonderzoek, dat uitgebreid beschreven is in het rapport 'Knelpunten op de arbeidsmarkt en personeelsbeleid in de openbare apotheek. ${ }^{8}$

Verder zal er speciale aandacht uitgaan naar twee groepen apothekersassistenten, namelijk de schoolverlaters en de herintreders. Immers, door het aannemen van schoolverlaters en herintreders kunnen de personeelstekorten in de openbare apotheek teruggedrongen worden. Apothekersassistenten die al werkzaam zijn in een openbare apotheek laten doorgaans bij vertrek naar een andere apotheek een vacature achter, die ook weer opgevuld dient te worden. Deze zogenaamde vacatureketens kunnen alleen maar gestopt worden met instroom van nieuwkomers buiten de apothekersbranche. Schoolverlaters en herintreders vormen verreweg het belangrijkste deel van deze instroom. ${ }^{9}$

\subsection{Opzet van het rapport}

De opzet van dit rapport is als volgt. Allereerst komt de monitoring van de verschillende aspecten van het werk als apothekersassistent in de openbare apotheek aan bod. In hoofdstuk 2 wordt de achtergrond van apothekersassistenten in kaart gebracht, zoals hun geslacht, leeftijd, gezinssituatie, reistijd en werkervaring. Hoofdstuk 3 beschrijft de ontwikkelingen in het werk van apothekersassistenten. Hun werkomstandigheden, de belangrijkste veranderingen in het werk en de tevredenheid met het werk staan in dit hoofdstuk centraal.

Daarna wordt een beeld geschetst van de employability van apothekersassistenten. Hoofdstuk 4 gaat in op de competentieontwikkeling van apothekersassistenten. Eerst worden de competenties van assistenten in de openbare apotheek beschreven. Daarna komt hun deelname aan cursussen en trainingen aan de orde en wordt onderzocht wat de gevolgen van deze scholing zijn voor het competentieniveau van apothekersassistenten in de openbare apotheek. In hoofdstuk 5 wordt vervolgens nagegaan hoe flexibel assistenten zijn wanneer het gaat om het aantal uren dat zij moeten werken. Tevens wordt beschreven in hoeverre apothekersassistenten in de openbare apotheek breed inzetbaar zijn: verrichten assistenten ook taken die niet tot hun functie behoren? Ten slotte komen in dit hoofdstuk de loopbaan- en arbeidsmarktperspectieven van apothekersassistenten binnen en buiten de apothekersbranche aan bod.

Hoofdstuk 6 gaat ten slotte in op een aantal mogelijke effecten van de verschillende aspecten van de employability van apothekersassistenten. In de eerste plaats wordt onderzocht of apothekersassistenten die cursussen volgen en die flexibel en breed inzetbaar zijn meer verdienen dan andere apothekersassistenten in de openbare apotheek. Daarna wordt de invloed van scholing, flexibiliteit en brede inzetbaarheid

8. A. de Grip, J. Sanders en I. Sieben (2002). Knelpunten op de arbeidsmarkt en personeelsbeleid in de openbare apotheek. ROA-R-2002/10, Maastricht.

9. A. de Grip en J.D. Vlasblom (1999). Toekomstverkenning arbeidsmarkt apothekersassistenten in de openbare apotheek. ROA-R-1999/7, Maastricht. 
op de werkdruk en het ziekteverzuim in kaart gebracht. Vervolgens komen de effecten op de tevredenheid van apothekersassistenten met hun werk aan de orde. Als laatste wordt nagegaan of het volgen van cursussen en het flexibel en breed inzetbaar zijn de loopbaan- en arbeidsmarktperspectieven van apothekersassistenten positief beï nvloeden. 


\section{Achtergrond van apothekersassistenten}

\subsection{Inleiding}

In dit hoofdstuk wordt een aantal persoonlijke kenmerken van apothekersassistenten beschreven. Hiermee wordt een antwoord gegeven op de eerste onderzoeksvraag van dit rapport: wat is de achtergrond van apothekersassistenten werkzaam in de openbare apotheek? Het gaat dan om de geslachts- en leeftijdsverdeling van assistenten (paragraaf 2.2), hun gezinssituatie en reistijd (paragraaf 2.3) en hun werkervaring (paragraaf 2.4). In paragraaf 2.5 ten slotte wordt aandacht besteed aan twee groepen apothekersassistenten: de schoolverlaters en herintreders. Deze twee groepen zijn interessant, aangezien het aannemen van voldoende schoolverlaters en herintreders cruciaal is voor het verminderen van de personeelstekorten in de openbare apotheek. Ook zullen we nagaan of er verschillen bestaan tussen zelfstandige apotheken en apotheken die tot een keten of maatschap behoren, tussen apotheken van verschillende omvang en tussen regio's.

\subsection{Geslacht en leeftijd}

Het is duidelijk dat het beroep van apothekersassistent een echt vrouwenberoep is. Slechts één op de honderd assistenten werkzaam in de openbare apotheek is een man. Het percentage mannen is de laatste jaren ook niet toegenomen. ${ }^{10}$

Figuur 2.1

Leeftijdsopbouw van apothekersassistenten werkzaam in de openbare apotheek, 2001

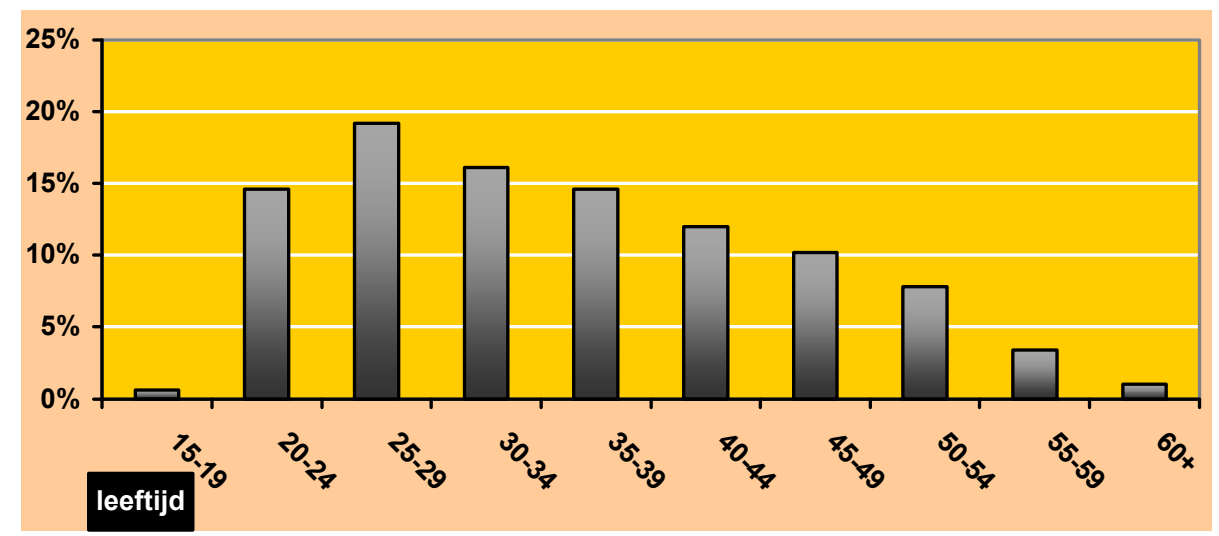

Bron: ROA

De gemiddelde leeftijd van apothekersassistenten is 36 jaar. Uit figuur 2.1 blijkt dat de meeste apothekersassistenten redelijk jong zijn; één op de drie assistenten is jonger dan 30 jaar. De piek in de leeftijdsverdeling ligt tussen de 25 en 30 jaar. Er zijn zeer weinig oudere assistenten; slechts $12 \%$ van de apothekersassistenten is

10. Zie A. de Grip en J.D. Vlasblom (1999). Toekomstverkenning arbeidsmarkt apothekersassistenten in de openbare apotheek. ROA-R-1999/7, Maastricht. 
ouder dan 50 jaar. Van deze oudere werknemers maakt overigens $64 \%$ gebruik van de seniorenregeling. Dit betekent dat zij onder bepaalde voorwaarden - met behoud van salaris - het aantal werkuren in 4 fasen kunnen verminderen tot een minimum van 20 uur per week. ${ }^{11}$

\section{Figuur 2.2}

Gemiddelde leeftijd van apothekersassistenten werkzaam in de openbare apotheek, naar regio van apotheek

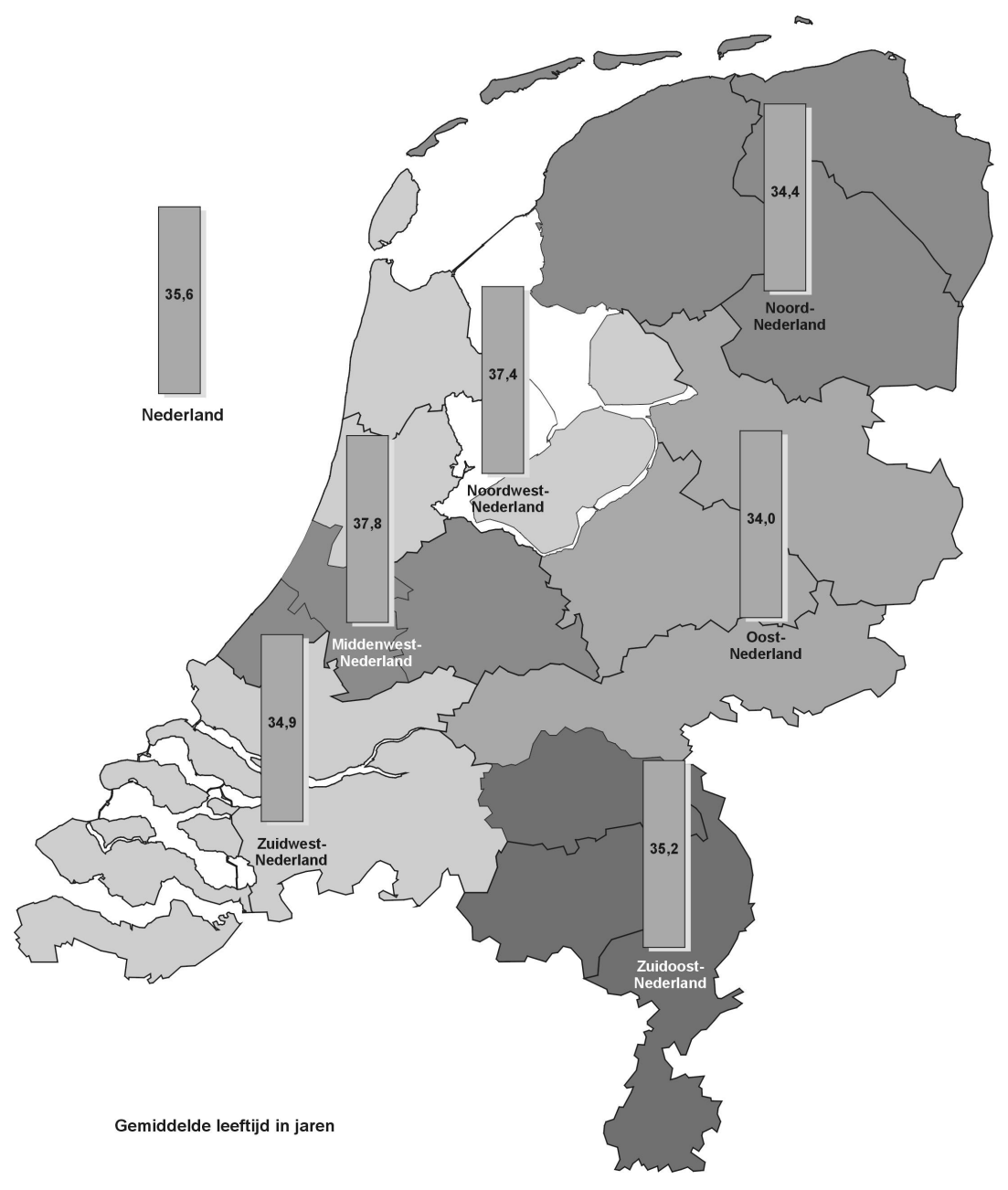

De leeftijdsverdeling van apothekersassistenten verschilt niet tussen zelfstandige en niet-zelfstandige apotheken. Ook zijn er geen verschillen tussen kleine en grote apotheken. Figuur 2.2 laat zien dat er wel sprake is van duidelijke regionale ver-

11. PMA (2002). Minder werken vanaf uw vijftigste met behoud van inkomen. Alles over de seniorenregeling van het Pensioenfonds Medewerkers Apotheken (PMA). Den Haag, www.pma-pensioenen.nl.

6 
schillen. De gemiddelde leeftijd in de Randstad (de regio's Noordwest en Middenwest) ligt een stuk hoger dan in de rest van Nederland. In de regio's Noord en Oost Nederland zijn de apothekersassistenten daarentegen relatief jong.

\subsection{Gezinssituatie en reistijd}

Tabel 2.1

Gezinssituatie van apothekersassistenten werkzaam in de openbare apotheek, 2001

\begin{tabular}{lccc}
\hline & $\begin{array}{c}\text { Partner } \\
\%\end{array}$ & $\begin{array}{c}\text { Geen partner } \\
\%\end{array}$ & $\begin{array}{c}\text { Totaal } \\
\%\end{array}$ \\
\hline Geen thuiswonende kinderen & 34 & 18 & 51 \\
Eén thuiswonend kind & 16 & 1 & 17 \\
Twee of meer thuiswonende kinderen & 30 & 2 & 32 \\
Totaal & 80 & 20 & 100 \\
\hline
\end{tabular}

Bron: ROA

Wat is de gezinssituatie van de apothekersassistenten die in de openbare apotheek werkzaam zijn? Tabel 2.1 geeft aan dat ongeveer de helft van de assistenten een partner en één of meer thuiswonende kinderen heeft. 34\% Heeft wel een partner, maar geen thuiswonende kinderen. Apothekersassistenten zonder partner hebben meestal geen kinderen. De partners van apothekersassistenten blijken overigens meestal een fulltime baan te hebben (88\%).

De laatste kolom van tabel 2.2 geeft een beeld van de leeftijdsverdeling van het jongste thuiswonende kind. Veel apothekersassistenten blijken de zorg te dragen voor een jong kind. Eén vijfde van de apothekersassistenten heeft een kind jonger dan 4 jaar; $11 \%$ heeft een kind tussen de 5 en 9 jaar. Overigens heeft de helft van de apothekersassistenten geen thuiswonende kinderen. Het betreft hier met name assistenten die jonger zijn dan 30 jaar of ouder dan 55 jaar. Tabel 2.2 laat ook zien of apothekersassistenten met thuiswonende kinderen gebruik maken van de faciliteiten voor kinderopvang zoals die door de werkgever aangeboden worden. ${ }^{12}$ Deze faciliteiten zijn met name populair onder apothekersassistenten met zeer jonge kinderen. Zo maakt $32 \%$ van de assistenten met kinderen in de leeftijd van 0 tot en met 2 jaar en $24 \%$ van de assistenten met kinderen van 3-4 jaar gebruik van door de werkgever aangeboden faciliteiten voor kinderopvang. Het meest opvallend is echter dat de overgrote meerderheid van de assistenten met jonge kinderen geen gebruik maken van de regelingen. Blijkbaar kunnen zij op een andere wijze opvang voor hun kind(eren) regelen. Er zijn overigens geen verschillen in het gebruik van de faciliteiten voor kinderopvang tussen zelfstandige en niet-zelfstandige apotheken, noch tussen apotheken van verschillende omvang en tussen regio's.

12. Uit het werkgeversonderzoek blijkt dat $19 \%$ van de apothekers deze faciliteiten aan assistenten aanbiedt. 
Tabel 2.2

Leeftijd jongste thuiswonende kind van apothekersassistenten werkzaam in de openbare apotheek en gebruik van faciliteiten voor kinderopvang aangeboden door de werkgever, 2001

\begin{tabular}{lccc}
\hline & $\begin{array}{c}\text { Wel gebruik } \\
\%\end{array}$ & $\begin{array}{c}\text { Geen gebruik } \\
\%\end{array}$ & $\begin{array}{c}\text { Totaal } \\
\%\end{array}$ \\
\hline $0-2$ jaar & 32 & 68 & 15 \\
$3-4$ jaar & 24 & 76 & 6 \\
10-14 jaar & 11 & 90 & 11 \\
15 jaar en ouder & 2 & 98 & 7 \\
Geen thuiswonende kinderen & 0 & 100 & 10 \\
Totaal & 0 & 100 & 51 \\
& 7 & 93 & 100 \\
\hline
\end{tabular}

Bron: ROA

Reistijd

Figuur 2.3 presenteert de gemiddelde reistijd van apothekersassistenten naar hun werk. De meeste apothekersassistenten wonen redelijk dicht bij de apotheek waar ze werkzaam zijn. Slechts één op de vijf apothekersassistenten doet er meer dan een half uur over om op het werk te komen. De gemiddelde reistijd van huis naar werk is 18 minuten. Assistenten zonder kinderen reizen wat langer naar hun werk, terwijl met name assistenten met kinderen in de leeftijd van 3 tot 10 jaar een kortere reistijd hebben. Kennelijk zoekt deze laatste groep, waarschijnlijk in verband met de schooltijden van hun kinderen, hun werk dichter bij huis. Ook assistenten die werkzaam zijn in een keten of maatschap van minder dan 5 apotheken wonen wat dichter bij hun werk. Er zijn geen verschillen in reistijd gevonden tussen assistenten die werken in kleine of in grote apotheken. Wel zijn er regionale verschillen: assistenten in de regio Noordwest Nederland reizen gemiddeld 21 minuten naar hun werk, terwijl apothekersassistenten in de regio Zuidoost Nederland er 17 minuten over doen.

Figuur 2.3

Gemiddelde enkele reistijd van apothekersassistenten werkzaam in de openbare apotheek (in minuten), 2001

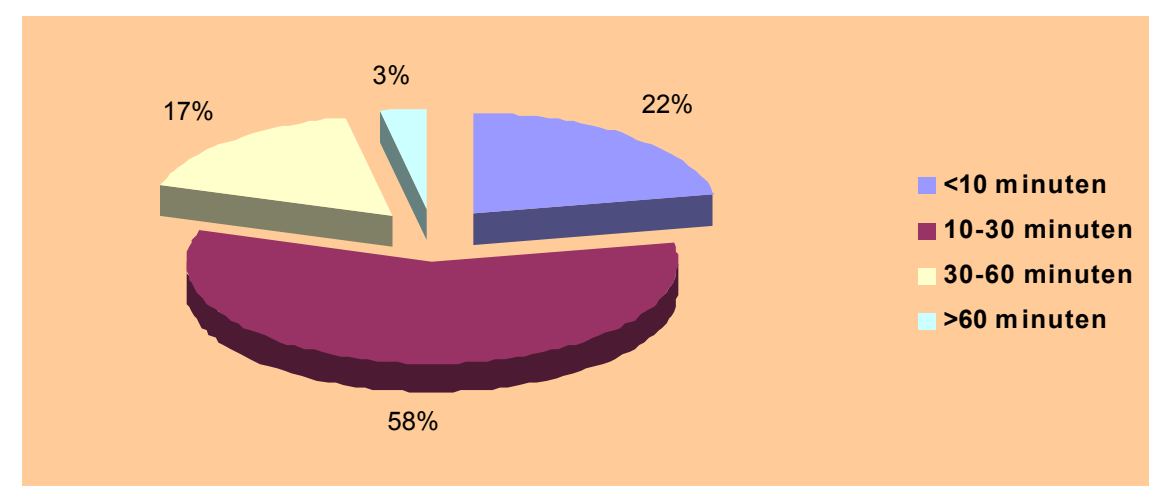

Bron: ROA 


\subsection{Werkervaring}

Figuur 2.4 geeft een beeld van de werkervaring van apothekersassistenten in de openbare apotheek. Gemiddeld genomen heeft een apothekersassistent bijna 15 jaar werkervaring. Wanneer we deze totale werkervaring wat nader bekijken, dan blijkt dat ongeveer $8 \%$ van de apothekersassistenten zeer weinig ervaring heeft (minder dan 5 jaar) en 14\% juist zeer veel ervaring (meer dan 25 jaar). De werkervaring als apothekersassistent is gemiddeld genomen 13 jaar en de werkervaring in de huidige apotheek 8 jaar. Overigens werkt $43 \%$ van de assistenten minder dan 5 jaar in de apotheek waar men nu werkzaam is. Hoewel veel apothekersassistenten dus al geruime tijd bij hun huidige werkgever werken, blijken wisselingen van werkgever ook voor te komen.

\section{Figuur 2.4}

Werkervaring van apothekersassistenten werkzaam in de openbare apotheek, naar regio van apotheek, 2001

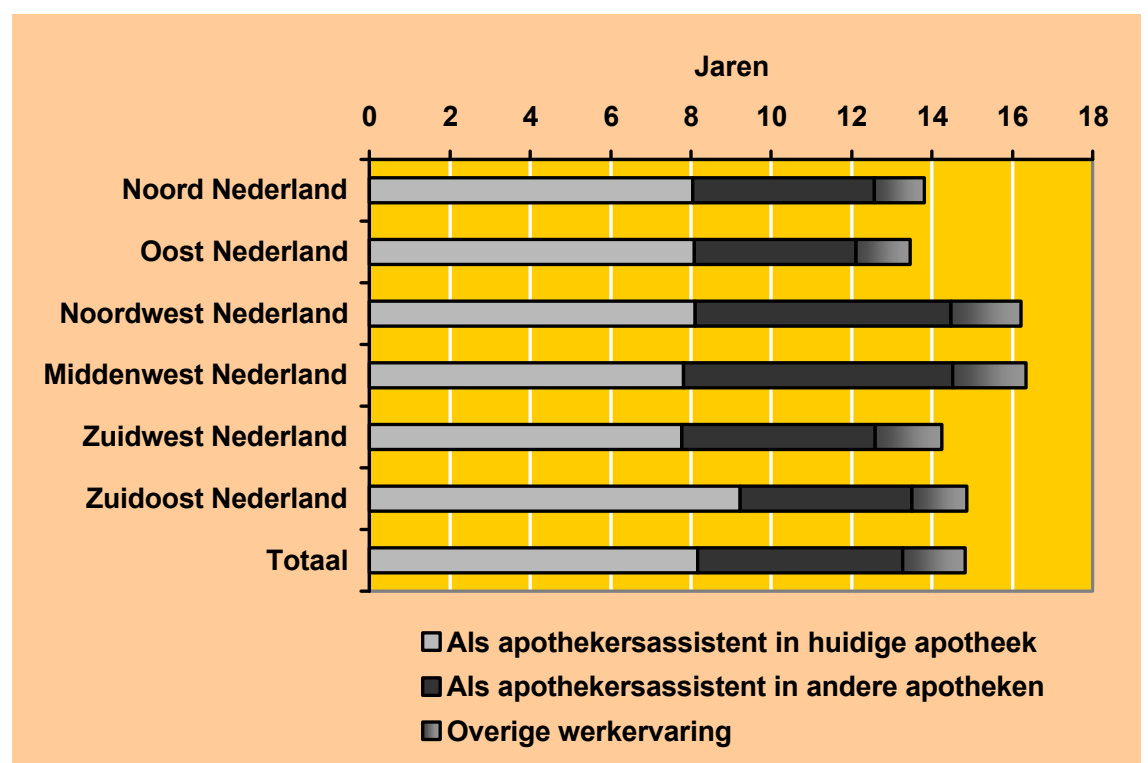

Bron: ROA

Figuur 2.4 laat ook de regionale verschillen in werkervaring zien. De totale werkervaring is significant groter voor apothekersassistenten in de Randstad (regio's Noordwest en Middenwest Nederland) en significant kleiner voor assistenten in de regio's Noord en Oost Nederland. Hetzelfde geldt voor de werkervaring als apothekersassistent. Hierbij moet opgemerkt worden dat dit zeer waarschijnlijk samenhangt met het feit dat assistenten in de Randstad over het algemeen wat ouder en in de regio's Noord en Oost Nederland wat jonger zijn. Ten slotte blijkt dat apothekersassistenten in de regio Zuidoost Nederland gemiddeld genomen wat langer (9 jaar) bij de huidige apotheek in dienst zijn dan in de overige regio's. Kennelijk is de honkvastheid in deze regio wat groter dan in de rest van het land. Er zijn geen duidelijke verschillen in de totale werkervaring, werkervaring als apothekersassistent en werk- 
ervaring in de huidige apotheek gevonden tussen zelfstandige en niet-zelfstandige apotheken. Ook zijn er geen verschillen tussen kleine en grote apotheken.

\subsection{Schoolverlaters en herintreders}

Tabel 2.3 laat zien dat $8 \%$ van de apothekersassistenten als schoolverlater getypeerd kan worden. We spreken hier van schoolverlaters als apothekersassistenten minder dan 3 jaar geleden hun opleiding hebben afgerond. Het percentage schoolverlaters is hetzelfde bij zelfstandige apotheken en apotheken die deel uitmaken van een keten of maatschap en verschilt ook niet tussen kleine en grote apotheken. Op het eerste gezicht lijken er in de regio Oost Nederland wat meer schoolverlaters te werken dan in de overige regio's, maar dit verschil is niet significant. Zoals verwacht mag worden zijn schoolverlaters wat jonger (gemiddeld 22 jaar) dan de gemiddelde apothekersassistent. Zij hebben minder vaak een partner en kinderen, en beschikken logischerwijs over minder werkervaring. Gemiddeld hebben zij 2 jaar als apothekersassistent gewerkt, waarvan 1 jaar in de huidige apotheek. Dit laatste wijst erop dat schoolverlaters in het eerste jaar van hun loopbaan vaak een overstap maken naar een andere openbare apotheek.

Tabel 2.3

Schoolverlaters en herintreders onder apothekersassistenten werkzaam in de openbare apotheek, naar regio van apotheek, 2001

\begin{tabular}{lcc}
\hline & $\begin{array}{c}\text { Recente } \\
\text { schoolverlaters } \\
\%\end{array}$ & $\begin{array}{c}\text { Herintreders } \\
\%\end{array}$ \\
\hline Noord Nederland & 7 & 12 \\
Oost Nederland & 10 & 14 \\
Noordwest Nederland & 6 & 20 \\
Middenwest Nederland & 7 & 20 \\
Zuidwest Nederland & 8 & 17 \\
Zuidoost Nederland & 7 & 14 \\
Totaal & 8 & 16 \\
\hline
\end{tabular}

\section{Bron: ROA}

\section{Herintreders}

Herintreders zijn apothekersassistenten die na hun opleiding een tijd gewerkt hebben, daarna met werken gestopt zijn - meestal om zorgtaken op zich te nemen - om vervolgens weer in de openbare apotheek te gaan werken. Uit tabel 2.3 blijkt dat het om $16 \%$ van de apothekerassistenten gaat. Men kan echter niet concluderen dat er meer herintreders dan schoolverlaters in de openbare apotheek werken. Herintreders die meer dan 3 jaar geleden weer zijn gaan werken worden hier immers ook als herintreder beschouwd, terwijl we van schoolverlaters spreken wanneer assistenten minder dan 3 jaar geleden hun opleiding hebben afgerond. Uit het werkgeversonderzoek blijkt dat $57 \%$ van de werkende apothekersassistenten in de openbare apotheek ooit is aangetrokken als schoolverlater. 
Herintredende apothekersassistenten hebben vaker een partner en kinderen, en beschikken ook over iets meer werkervaring als apothekersassistent dan de gemiddelde assistent: ongeveer 15 jaar. De soort en de omvang van de apotheek hebben geen invloed op het percentage herintreders in de apotheek. Wel blijken er in de Randstad beduidend meer herintreders in dienst te zijn dan in de overige regio's. Dit verklaart waarschijnlijk waarom de gemiddelde leeftijd van apothekersassistenten in deze regio's wat hoger ligt. Herintredende apothekersassistenten zijn immers wat ouder (gemiddeld zo'n 45 jaar) dan andere apothekersassistenten. Dat apothekers in de regio's Noordwest en Middenwest Nederland meer herintreders in dienst nemen, heeft mogelijk te maken met de grote knelpunten in de personeelsvoorziening die zij ervaren. Het werkgeversonderzoek laat immers zien dat apotheken in deze regio's geconfronteerd worden met een hoge vacaturegraad en een groot personeelsverloop. Wellicht proberen zij door het aannemen van herintreders deze problemen de baas te worden. Herintreders zijn immers over het algemeen niet de eerste keus voor apothekers; het werkgeversonderzoek toont aan dat de voorkeur van apothekers vaak uitgaat naar schoolverlaters. Wanneer er echter sprake is van meer knelpunten in de personeelsvoorziening, neemt de voorkeur voor herintreders doorgaans toe.

\section{Motieven van herintreders}

De herintreders hebben in de enquête aangegeven waarom ze weer in een openbare apotheek zijn gaan werken. Bijna alle herintreders (89\%) zeggen weer als apothekersassistent te zijn gaan werken omdat ze terug in het vak wilden. Het beroep van apothekersassistent oefent dus een grote aantrekkingskracht op herintreders uit. Opvallend is verder dat iets meer dan een kwart van de herintreders is gevraagd door een oud-collega of vriendin. Dit duidt erop dat dit informele netwerk een belangrijke rol speelt bij het overhalen van herintreders om terug te keren in de openbare apotheek.

Figuur 2.5 geeft een overzicht van de overwegingen die meegespeeld hebben bij de keuze van herintreders om weer te gaan werken. Als positieve overwegingen worden door veel herintreders de mogelijkheid tot deeltijdwerk $(79 \%)$, het combineren van werk en zorgtaken (71\%) en de werksfeer (64\%) genoemd. Ook de reistijd (45\%) en de financiële beloning (44\%) worden als positieve overwegingen genoemd. De onregelmatige diensten die bij het vak van apothekersassistent horen worden als negatief beschouwd. Bij de keuze om weer in de openbare apotheek te gaan werken was dit voor bijna $30 \%$ van de herintreders een negatieve overweging. Daarnaast worden de salariëring (14\%) en de loopbaanperspectieven (13\%) van assistenten als negatieve overwegingen genoemd. Niet-participerende apothekersassistenten geven deze drie zaken overigens ook als redenen op waarom ze achteraf gezien niet voor de opleiding tot apothekersassistent gekozen zouden hebben, zo blijkt uit het rapport 'Het onbenutte arbeidspotentieel van apothekersassistenten voor de openbare apotheek. ${ }^{13}$

13. F. Cörvers, B.J. Diephuis en B. Golsteyn (2002). Het onbenutte arbeidspotentieel van apothekersassistenten voor de openbare apotheek, ROA-R-2002/2, Maas tricht. 
Figuur 2.5

Overwegingen van herintreders bij de keuze om terug te leren naar de openbare apotheek, 2001

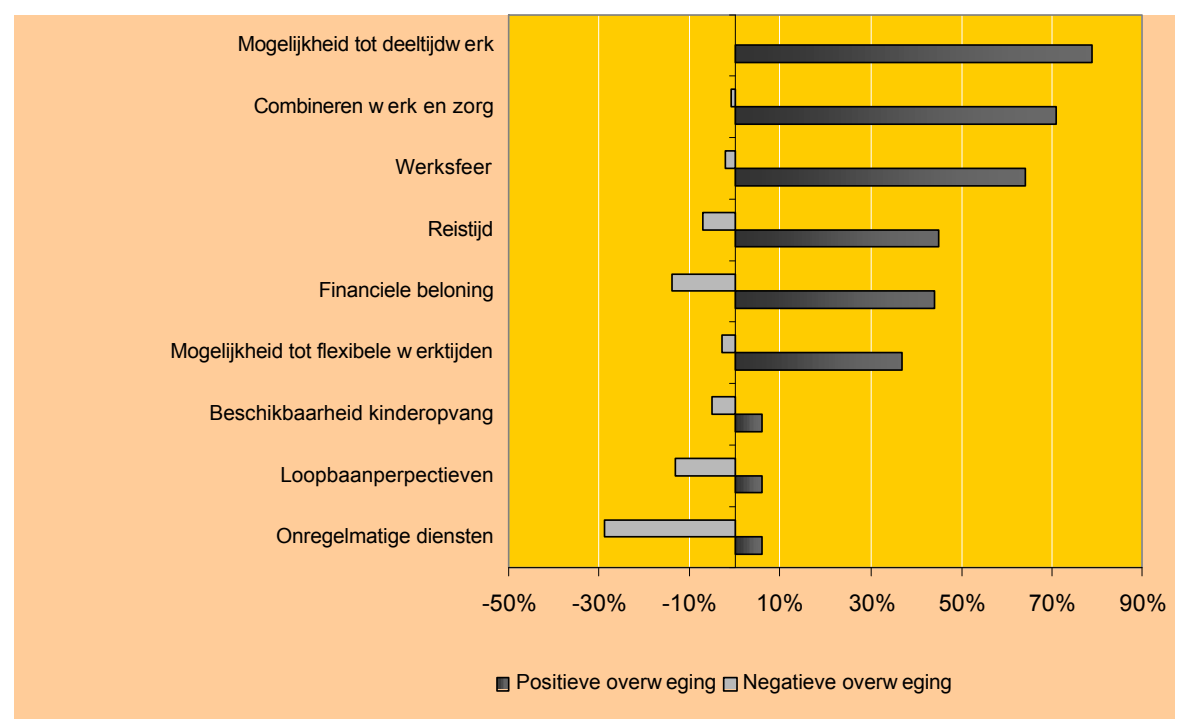

Bron: ROA

Het is dus duidelijk dat een deel van de apothekers er goed in slaagt om herintreders aan te trekken, met name omdat zij hen de mogelijkheid bieden om werk en zorgtaken te combineren. In dit opzicht zijn vooral kleine deeltijdbanen (16 tot 24 uur) aantrekkelijk voor mensen die weer in de openbare apotheek willen gaan werken. 


\section{Ontwikkelingen in het werk}

\subsection{Inleiding}

In dit hoofdstuk wordt een antwoord gegeven op de vraag welke ontwikkelingen zich voordoen in het werk van apothekersassistenten in de openbare apotheek. Hiertoe worden allereerst in paragraaf 3.2 de werkomstandigheden van apothekersassistenten beschreven. Welk soort contract hebben zij, hoeveel uur per week wordt er gewerkt, en wat zijn hun werktijden? Hoe staat het met de werkdruk en het ziekteverzuim onder apothekersassistenten? En hoeveel verdienen de assistenten die werkzaam zijn in de openbare apotheek? Daarna komen in paragraaf 3.3 recente ontwikkelingen in de openbare apotheek aan bod. Met welke veranderingen in hun werk hebben apothekersassistenten te maken en welke problemen ondervinden zij bij deze veranderingen? Paragraaf 3.4 ten slotte beschrijft de tevredenheid van apothekersassistenten met hun werk in de openbare apotheek. Niet alleen de tevredenheid met verschillende aspecten van het werk (zoals werktijden, salaris en inhoud van het werk) maar ook de tevredenheid met de door de werkgever geboden regelingen en faciliteiten wordt onderzocht.

\subsection{Werkomstandigheden}

\section{Tabel 3.1}

Soort contract van apothekersassistenten werkzaam in de openbare apotheek, naar schoolverlaters en herintreders, 2001

\begin{tabular}{lccc}
\hline & $\begin{array}{c}\text { Schoolverlaters } \\
\%\end{array}$ & $\begin{array}{c}\text { Herintreders } \\
\%\end{array}$ & $\begin{array}{c}\text { Totaal } \\
\%\end{array}$ \\
\hline Vast contract & 90 & 91 & 96 \\
Tijdelijk contract met uitzicht op vast & 9 & 6 & 3 \\
Tijdelijk contract zonder uitzicht op vast & 1 & 1 & 1 \\
Oproepbasis & 1 & 2 & 1 \\
\hline
\end{tabular}

Bron: ROA

Uit tabel 3.1 blijkt dat het overgrote deel van de apothekersassistenten een vast contract heeft. ${ }^{14}$ Het zijn de jongere assistenten en de assistenten met weinig werkervaring die vaker volgens een ander contract werkzaam zijn. Met name schoolverlaters hebben vaker een tijdelijk contract met uitzicht op een vaste aanstelling. Maar ook herintreders werken significant minder vaak met vast contract. Er zijn op dit punt geen verschillen gevonden tussen zelfstandige en niet-zelfstandige apotheken noch tussen kleine en grote apotheken en tussen regio's.

14. Het percentage apothekersassistenten met een vast contact is wat hoger dan in het werkgeversonderzoek gevonden wordt. Dit kan te maken hebben met het feit dat assistenten met een vast contract meer betrokken zijn bij het werk in de apotheek, en dus ook eerder geneigd zijn aan een enquête deel te nemen die over verschillende aspecten van hun werk gaat. Uit aanvullend onderzoek (zie bijlage A) blijkt wel dat de assistenten die aan de enquête meewerken een representatieve groep vormen wat geslacht, leeftijd en regio betreft. 


\section{Werkuren}

Apothekersassistenten werken gemiddeld 26,7 uur per week. Dit betekent dat er uitgaande van een voltijdse werkweek van 36 uur - per $100 \mathrm{fte} 135$ assistenten werkzaam zijn. Het soort contract dat zij hebben, maakt geen verschil voor het aantal uren dat men werkt. Alleen apothekersassistenten op oproepbasis werken veel minder uren per week (gemiddeld 10,8 uur). Tabel 3.2 laat zien dat het aantal uren dat assistenten werkzaam zijn, zoals verwacht mocht worden, sterk samenhangt met hun gezinssituatie. Van de apothekersassistenten zonder kinderen heeft de meerderheid $(61 \%)$ een fulltime baan. Assistenten met kinderen werken bijna allemaal in deeltijd. Vooral wanneer er jonge kinderen zijn, is het aantal uren dat men werkt gering. Ongeveer de helft van de apothekersassistenten met kinderen jonger dan 10 jaar werkt minder dan 20 uur per week. Assistenten met wat oudere kinderen werken vaak 20 tot 32 uur per week (56\%).

Tabel 3.2

Werkuren per week van apothekersassistenten werkzaam in de openbare apotheek, naar gezinssituatie, 2001

\begin{tabular}{lccccc}
\hline & $\begin{array}{c}\text { Zonder } \\
\text { kinderen }\end{array}$ & $\begin{array}{c}\text { Met jonge } \\
\text { kinderen } \\
(0-9 \text { jaar }) \\
\%\end{array}$ & $\begin{array}{c}\text { Met oudere } \\
\text { kinderen } \\
(10+\text { jaar }) \\
\%\end{array}$ & Herintreders & Totaal \\
\hline Minder dan 20 uur per week & 5 & 47 & 31 & 39 & 23 \\
20 tot 32 uur per week & 16 & 47 & 56 & 50 & 33 \\
32 tot 36 uur per week & 17 & 3 & 6 & 6 & 11 \\
36 uur per week of meer & 61 & 3 & 7 & 6 & 34 \\
\hline
\end{tabular}

\section{Bron: ROA}

Tabel 3.2 laat verder zien dat ook herintreders vaak (kleine) deeltijdbanen hebben. Slechts $12 \%$ van hen werkt 32 uur per week of meer. Er bestaat geen relatie tussen het aantal uren dat assistenten per week werken en het soort apotheek waar ze werkzaam zijn, of de omvang van de apotheek. Wel zijn er regionale verschillen te vinden. In de regio Noord Nederland werken assistenten wat meer uren per week (gemiddeld 28,1 uur), terwijl assistenten in de Randstad wat minder uren per week werken (gemiddeld 25,6 uur). Dit heeft waarschijnlijk te maken met de leeftijd van de apothekersassistenten; in de regio Noord Nederland zijn zij over het algemeen wat jonger dan in de Randstad.

\section{Werktijden}

Tabel 3.3 geeft een overzicht van de werktijden in de openbare apotheek. $63 \%$ Van de apothekersassistenten heeft te maken met regelmatige werktijden waarbij men alleen overdag werkt. 56\% Heeft regelmatige werktijden met een combinatie van dag-, avond-, nacht- en/of weekenddiensten. Onregelmatige diensten komen weinig voor. Slechts $10 \%$ van de assistenten heeft hiermee te maken. Schoolverlaters hebben het meest te maken met onregelmatige, door de werkgever bepaalde, werktijden (16\%). Herintreders daarentegen worden significant minder vaak ingezet in onregelmatige, zaterdags-, zondags-, avond/nacht-, aanwezigheids-, of bereikbaarheiddiensten. Ook 
hier is weer een verband te leggen met de gezinssituatie van de apothekersassistenten. Assistenten met kinderen werken beduidend minder in de genoemde diensten. Dit geldt echter niet voor apothekersassistenten met zeer kleine kinderen ( 0 tot 4 jaar); zij worden wel vaak in onregelmatige en weekend- en avonddiensten ingezet.

Tabel 3.3

Werktijden van apothekersassistenten werkzaam in de openbare apotheek, $2001^{\mathrm{a}}$

\begin{tabular}{lc}
\hline & $\%$ \\
\hline Regelmatige werktijden, alleen overdag & 63 \\
Regelmatige werktijden, met dag-, avond-, nacht- en/of weekenddiensten & 56 \\
Onregelmatige, door werkgever bepaalde, werktijden & 10 \\
Werken op zaterdag & 50 \\
Werken op zondag & 40 \\
Avond- of nachtdiensten & 46 \\
Aanwezigheidsdiensten in de avond en op zaterdag en zondag & 31 \\
Bereikbaarheidsdiensten & 22 \\
\hline & \\
amdat apothekersassistenten met meerdere situaties te maken kunnen hebben, tellen deze \\
percentages niet op tot 100\%. \\
Bron: ROA \\
Het zal geen verbazing wekken dat de werktijden van apothekersassistenten per \\
apotheek verschillen. Bereikbaarheiddiensten komen wat vaker voor in zelfstandige \\
apotheken, en wat minder vaak in apotheken die deel uitmaken van een keten of \\
maatschap van meer dan 5 apotheken. Assistenten in kleine apotheken hebben \\
minder vaak te maken met avond-, nacht-en/of weekenddiensten en bereikbaar- \\
heidsdiensten dan assistenten in de grotere apotheken. Deze diensten komen wat \\
vaker voor bij assistenten die werkzaam zijn in de regio 's Noord en Oost Nederland, \\
en wat minder vaak bij assistenten werkzaam in de Randstad.
\end{tabular}

\section{Werkdruk}

Tabel 3.4 geeft een beeld van de werkdruk van apothekersassistenten. Met name het werken onder een hoge tijdsdruk blijkt veelvuldig in de openbare apotheek voor te komen. lets meer dan de helft van de apothekersassistenten geeft aan regelmatig onder hoge tijdsdruk te werken, terwijl nog eens $42 \%$ zegt hier soms mee te maken te hebben. Deze percentages liggen hoger dan bij de werkenden in de verpleging, waar vaak signalen van een hoge werkdruk zijn, en veel hoger dan in de administratieve functies. ${ }^{15}$ Ook in de detailhandel, een sector die veel raakvlakken heeft met de apothekersbranche, komt het werken onder hoge tijdsdruk veel minder vaak voor. In 1999 gaf $20 \%$ van de werknemers in de detailhandel aan regelmatig onder hoge tijdsdruk te werken; $27 \%$ had hier soms mee te maken. ${ }^{16}$ Een aanzienlijk deel van de assistenten (29\%) vindt het werk regelmatig geestelijk zwaar, en één vijfde geeft aan regelmatig onder slechte fysieke omstandigheden te werken. Daarentegen vindt slechts $6 \%$ van de assistenten dat ze regelmatig eentonig werk verrichten. Overigens

15. ROA (2002). Werkgelegenheid en scholing 2001. ROA-R-2002/7, Maastricht.

16. Bron: http://www.cbs.nl/nl/cijfers/statline/index.htm. 
blijkt uit het werkgeversonderzoek dat de apothekers de werkdruk van apothekersassistenten in de openbare apotheek ook hoog vinden. ${ }^{17}$

Tabel 3.4

Werkdruk van apothekersassistenten werkzaam in de openbare apotheek, 2001

\begin{tabular}{lccc}
\hline & $\begin{array}{c}\text { Regelmatig } \\
\%\end{array}$ & $\begin{array}{c}\text { Soms } \\
\%\end{array}$ & $\begin{array}{c}\text { Nooit } \\
\%\end{array}$ \\
\hline Hoge tijdsdruk & 54 & 42 & 5 \\
Geestelijk zwaar werk & 29 & 56 & 15 \\
Lichamelijk zwaar werk & 10 & 54 & 36 \\
Slechte fysieke arbeidsomstandigheden & 20 & 51 & 30 \\
Eentonig werk & 6 & 39 & 54 \\
\hline
\end{tabular}

Bron: ROA

Vooral schoolverlaters en assistenten in kleine apotheken geven aan minder vaak regelmatig onder een hoge tijdsdruk te moeten werken. Ook zijn er duidelijke regionale verschillen in de werkdruk te vinden. Apothekersassistenten in de regio's Noordwest, Middenwest en Zuidwest Nederland ervaren vaker een hoge tijdsdruk, lichamelijk zwaar werk en slechte fysieke arbeidsomstandigheden dan assistenten in de regio's Noord en Oost Nederland.

\section{Ziekteverzuim}

Tabel 3.5 laat zien dat assistenten in 2001 gemiddeld 9,5 dagen ziek geweest zijn. Ongeveer de helft van de assistenten verzuimde in die periode geen enkele dag. Het ziekteverzuim onder apothekersassistenten in de openbare apotheek komt daarmee op 4,6\%. Dit is lager dan het ziekteverzuim dat door de apothekers gerapporteerd wordt (zie werkgeversonderzoek). Dit verschil kan verklaard worden door de andere manier van vraagstellen ${ }^{18}$, en door een mogelijke onderrapportage van het ziekteverzuim doordat apothekersassistenten die enkele maanden geleden één of enkele dagen ziek waren, hier mogelijk bij het invullen van de enquête niet meer aan dachten.

Herintreders en oudere assistenten blijken wat vaker ziek te zijn dan jongere apothekersassistenten. Er worden geen verschillen in het ziekteverzuim gevonden tussen assistenten met of zonder kinderen. Ook zijn er op dit punt geen verschillen tussen zelfstandige en niet-zelfstandige apotheken, tussen apotheken van verschillende omvang of tussen regio's.

17. Het begrip werkdruk is subjectief: het gaat hier om de werkdruk van apothekersassistenten zoals die door de assistenten zelf (werknemersonderzoek) of door hun apothekers (werkgeversonderzoek) ingeschat wordt. De door de apothekers ingeschatte werkdruk van apothekersassistenten blijkt overigens samen te hangen met de werklast, dat wil zeggen het aantal receptregels dat in een apotheek voorgeschreven wordt. Deze samenhang is het hoogst in Zuidwest en Noord Nederland en het laagst in de regio Noordwest Nederland.

18. Aan de apothekersassistenten is een retrospectieve vraag gesteld: zij moesten het aantal ziektedagen in het afgelopen jaar invullen. De apothekers werd gevraagd naar het aantal apothekersassistenten dat op het moment van de werkgeversenquête (november 2001) ziek was. 
Tabel 3.5

Oorzaken en gemiddeld aantal dagen ${ }^{a}$ ziekteverzuim in 2001 van apothekersassistenten werkzaam in de openbare apotheek, 2001

\begin{tabular}{lrc}
\hline Oorzaak ziekteverzuim & $\%$ & Gemiddeld aantal dagen \\
\hline Geheel bij werk & 2 & 50,5 \\
Gedeeltelijk bij werk & 7 & 31,2 \\
Niet bij werk & 42 & 15,2 \\
Niet ziek geweest & 49 & 0,0 \\
Totaal & 100 & 9,5
\end{tabular}

a gecorrigeerd voor het werken in deeltijd Bron: ROA

De oorzaak van het ziekteverzuim onder apothekersassistenten lag in $2 \%$ van de gevallen geheel en in $7 \%$ gedeeltelijk bij het werk. Opvallend hierbij zijn de verschillen in het gemiddeld aantal dagen dat men ziek was. Assistenten die aangeven dat de oorzaak van hun ziekzijn geheel bij het werk te vinden is, verzuimen gemiddeld maar liefst 50,5 dagen. Wanneer de oorzaak van het ziekteverzuim gedeeltelijk bij het werk ligt, dan is het gemiddelde 31,2 dagen. Assistenten die de oorzaak van hun ziekte buiten het werk benoemen, verzuimen gemiddeld maar 15,2 dagen. Uit deze cijfers kan worden afgeleid dat ruim $17 \%$ van het totale ziekteverzuim geheel of gedeeltelijk samenhangt met het werk. Als dit verlies met de helft zou kunnen worden teruggedrongen, dan staat dit gelijk aan een extra arbeidspotentieel van circa 70 fulltime werkende apothekersassistenten per jaar. ${ }^{19}$ Deze cijfers benadrukken nogmaals de noodzaak om het werkgerelateerde ziekteverzuim in de openbare apotheek - waar mogelijk - terug te dringen.

\section{Salaris}

Wat verdienen apothekersassistenten die werkzaam zijn in de openbare apotheek? Tabel 3.6 geeft aan dat het gemiddelde netto salaris bij een 36-urige werkweek $€$ $1.366,-$ per maand bedraagt. ${ }^{20}$ Schoolverlaters verdienen minder dan herintreders (€.1.043,- tegen $€ 1.421,-)$. Natuurlijk speelt de werkervaring van assistenten bij de bepaling van het salaris een grote rol. Zo verdienen apothekersassistenten in de openbare apotheek met minder dan 5 jaar werkervaring netto gemiddeld $€ 1.089$, per maand. Dit loopt op tot bijna $€ 1.500$,- netto bij meer dan 20 jaar werkervaring. Er zijn geen significante verschillen in het salaris van apothekersassistenten tussen

19. Deze cijfers zijn als volgt berekend. In de werknemersenquête gaven 281 van de 3.162 assistenten aan in 2001 ziek te zijn geweest door een oorzaak die geheel of gedeeltelijk bij het werk lag. Zij verzuimden in totaal 7.280 dagen. Wanneer deze cijfers worden doorgetrokken naar de gehele apothekersbranche, waar 12.523 assistenten werkzaam zijn, dan komt dit neer op $12.523 \times(281 / 3.162)=1.113$ assistenten die in totaal $7.280 \times$ $(1.113 / 281)=28.832$ dagen in 2001 verzuimden. Een fulltime werkende apothekersassistent werkt 206 dagen per jaar. Terugdringen van het ziekteverzuim met de helft zou een arbeidspotentieel van $28.832 \times 0,5 / 206=70$ fulltime werkende assistenten op jaarbasis opleveren.

20. Omgerekend naar een bruto maandsalaris komt dit bedrag ongeveer overeen met het bruto maandsalaris zoals vermeld in het werkgeversonderzoek. 
zelfstandige en niet-zelfstandige apotheken. Ook zijn er geen salarisverschillen tussen kleine en grote apotheken en tussen regio's.

\section{Tabel 3.6}

Gemiddeld netto maandinkomen in euro van apothekersassistenten werkzaam in de openbare apotheek naar schoolverlater, herintreder en werkervaring als apothekersassistent, 2001

\begin{tabular}{ll}
\hline & \\
& Gemiddeld netto maandinkomen $^{\mathrm{a}}$ \\
\hline Schoolverlater & \\
Herintreder & $€ 1.043,-$ \\
& $€ 1.421,-$ \\
Werkervaring als apothekersassistent & \\
4 jaar of minder & $€ 1.089,-$ \\
$5-9$ jaar & $€ 1.253,-$ \\
$10-14$ jaar & $€ 1.461,-$ \\
$15-19$ jaar & $€ 1.486,-$ \\
$20-24$ jaar & $€ 1.497,-$ \\
$25-29$ jaar & $€ 1.498,-$ \\
30 jaar of meer & $€ 1.510,-$ \\
& $€ 1.366,-$
\end{tabular}

${ }^{a}$ Het betreft hier het gemiddeld netto inkomen per maand bij een 36-urige werkweek in euro. Bron: ROA

\subsection{Veranderingen in het werk}

Op welke terreinen doen zich de belangrijkste veranderingen in het werk van apothekersassistenten voor? Figuur 3.2 laat zien dat de assistenten als belangrijkste veranderingen noemen: de mondigheid van cliënten $(72 \%)$, de intensievere patiëntenvoorlichting $(64 \%)$, minder bereidingen (61\%), klantgerichtheid $(52 \%)$ en verhoging van de werklast $(52 \%)$. Uit het werkgeversonderzoek kwam naar voren dat ook de apothekers van mening zijn dat de service en het contact met de cliënt steeds belangrijkere aspecten van het werk van apothekersassistenten worden. Opvallend hierbij is dat de apothekers met name de intensievere patiëntenvoorlichting noemen (82\%), terwijl de assistenten de nadruk leggen op de mondigheid van de cliënten (72\%). Waarschijnlijk hebben de apothekersassistenten op een meer directe wijze te maken met de mondigheid van de cliënten dan de apothekers. Apothekers wijzen daarnaast op het belang van veranderingen in de vereiste geneesmiddelenkennis $(52 \%)$, terwijl dit door de apothekersassistenten veel minder vaak genoemd wordt (38\%). Koppeling met het artsensysteem en gebruik van nieuwe computersystemen worden weer vaker door de apothekersassistenten dan door de apothekers als belangrijke veranderingen in het werk gezien.

De assistenten die werkzaam zijn in de kleine apotheken noemen het verzorgen van spreekuren en de intensievere patiëntenvoorlichting minder vaak als belangrijke veranderingen in hun werk dan assistenten in de grotere apotheken. Ook zijn er enkele regionale verschillen. Assistenten in de regio Noord Nederland vinden het verzorgen van spreekuren, de intensievere patiëntenvoorlichting en het verplaatsen van de farmaceutische zorg naar de thuissituatie belangrijke veranderingen. Ten slotte wordt een verhoging van de werklast met name in de Randstad - zowel door de apothekersassistenten als de apothekers - genoemd. 
Figuur 3.2

Veranderingen in het werk van apothekersassistent, volgens apothekersassistenten en volgens apothekers, $2001^{\mathrm{a}}$

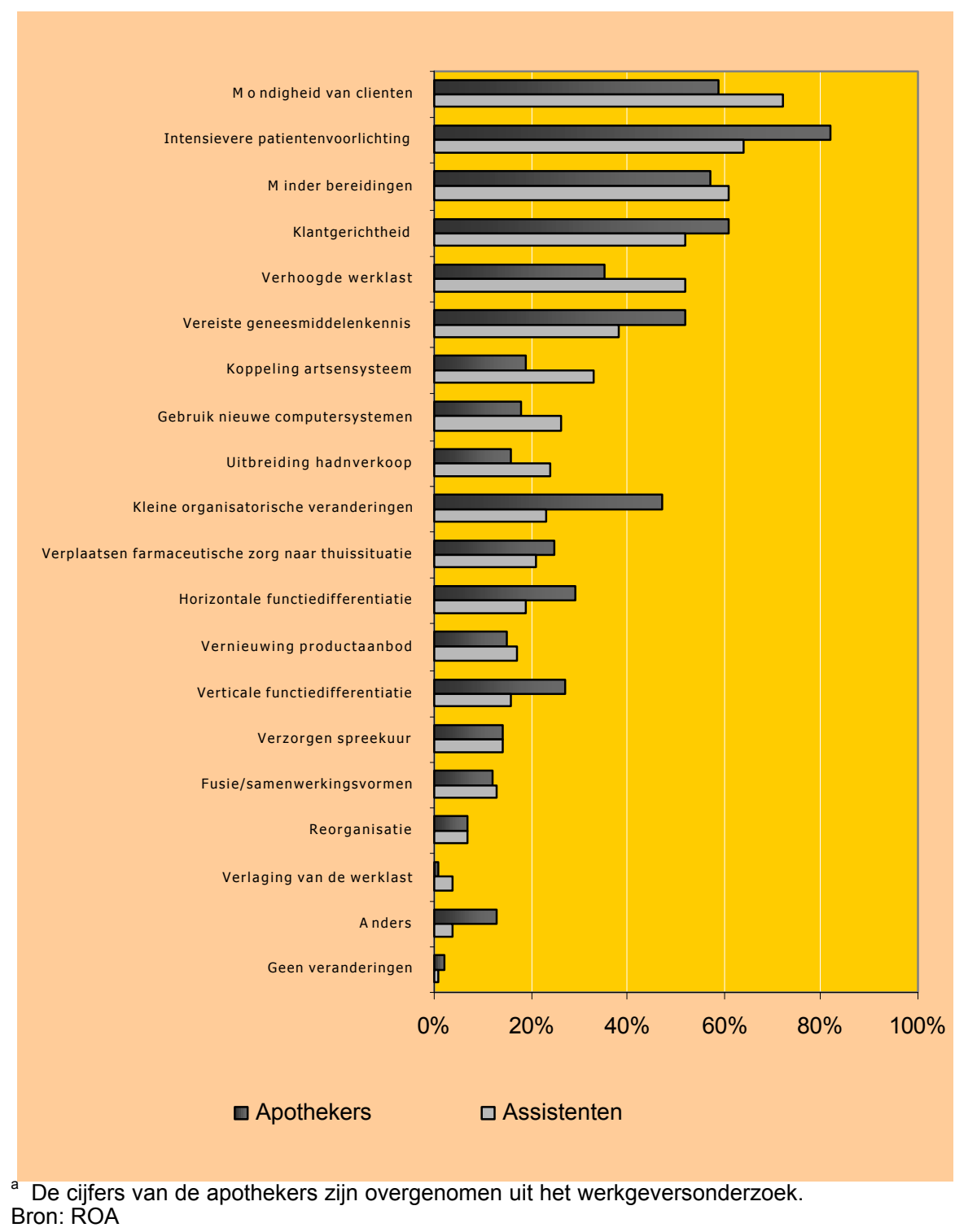

Ongeveer één op de vijf apothekersassistenten werkzaam in de openbare apotheek geeft aan geen moeite te hebben zich aan deze veranderingen aan te passen (zie figuur 3.3). Toch heeft een aanzienlijk deel van de assistenten hier wel degelijk enige moeite mee (34\%); $2 \%$ van de assistenten zegt zelfs (zeer) veel moeite te hebben met het aanpassen aan deze veranderingen. Over het algemeen vinden oudere werknemers, assistenten met veel werkervaring en herintreders het moeilijker om zich aan de veranderingen in de openbare apotheek aan te passen. Schoolverlaters hebben daarentegen minder moeite met de genoemde veranderingen. Dit houdt waarschijnlijk verband met de grotere mate van flexibiliteit bij jonge werknemers. 
Daarnaast zou er ook sprake kunnen zijn van het tekortschieten van bepaalde competenties bij assistenten die lang geleden van school zijn gegaan. Omdat het contact met de cliënt steeds belangrijker wordt in het werk, wordt er steeds meer een beroep gedaan op de communicatieve vaardigheden van de apothekersassistent. Herintreders en assistenten met meer werkervaring scoren inderdaad beduidend lager op deze vaardigheden, zoals uit hoofdstuk 4 van dit rapport zal blijken.

Het belangrijkste probleem bij het aanpassen aan de veranderingen in de openbare apotheek is tijdgebrek; $52 \%$ van de apothekersassistenten noemt dit het belangrijkste aanpassingsprobleem. Daarna volgen een gebrekkige communicatie met de leidinggevende apotheker (15\%) en te weinig begeleiding (13\%). Met name herintreders vinden dit laatste een belangrijk probleem. Opvallend is verder dat het hebben van te weinig ervaring of kennis slechts door $1 \%$ van de apothekersassistenten als een probleem genoemd wordt.

\section{Figuur 3.3}

Moeite met aanpassen aan veranderingen in het werk van apothekersassistenten in de openbare apotheek, 2001

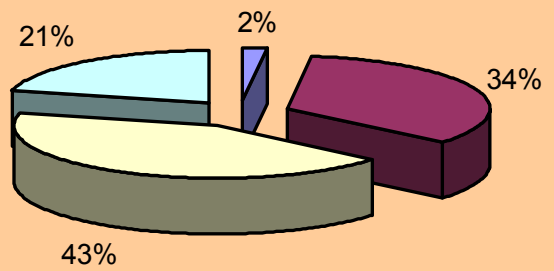

$\square($ Zeer) veel moeite

口Enige moeite

$\square$ Vrijwel geen moeite

$\square$ Geen moeite

Bron: ROA

\subsection{Tevredenheid met het werk}

Ten slotte is nagegaan hoe tevreden apothekersassistenten zijn met hun werk in de openbare apotheek. Figuur 3.4 geeft aan dat het overgrote deel van de apothekersassistenten over het algemeen (zeer) tevreden is met hun huidige baan (87\%). Deze cijfers komen overeen met het percentage tevreden werknemers in de zorgsector. Voor alle werkenden in Nederland ligt het percentage tevredenen iets hoger $(92 \%) .{ }^{21}$ Ongeveer één op de tien apothekersassistenten is niet zo tevreden, en slechts $2 \%$ is helemaal niet tevreden.

Overigens zijn de schoolverlaters het meest tevreden van alle apothekersassistenten. Er bestaan geen significante verschillen in tevredenheid met het werk tussen

21. G. van Essen, H.E. Meihuizen en F. Peters (2001). Arbeid in Zorg en Welzijn. Integrerend OSA-rapprt 2001. OSA-publicatie ZW20, Tilburg. 
assistenten in zelfstandige en niet-zelfstandige apotheken, in kleine en grote apotheken en de diverse regio's.

Figuur 3.4

Tevredenheid met huidige baan van apothekersassistenten werkzaam in de openbare apotheek, 2001

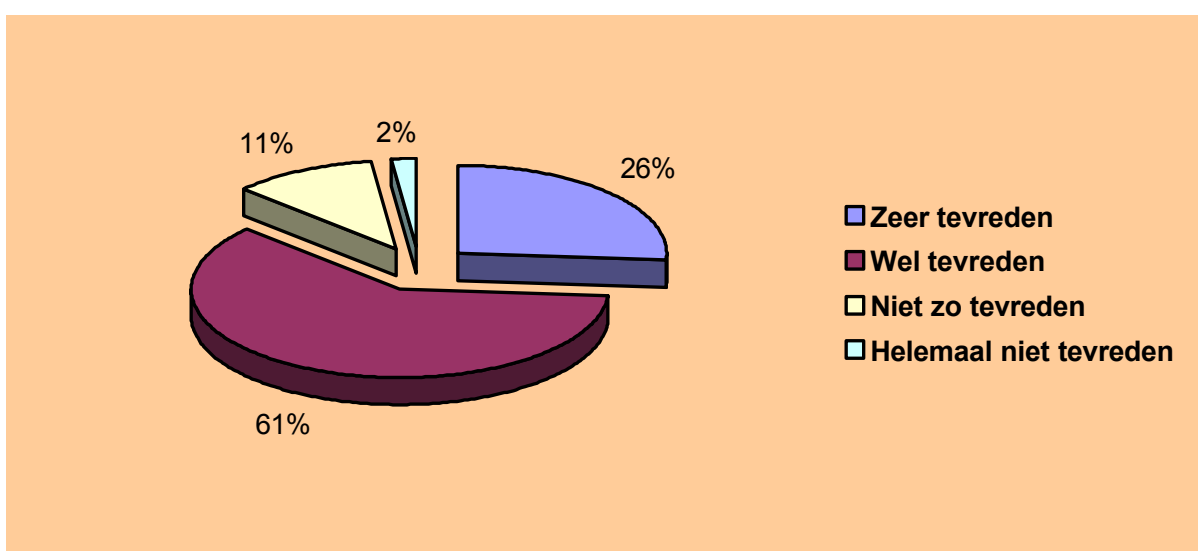

Bron: ROA

Figuur 3.5

Tevredenheid met verschillende aspecten van het werk van apothekersassistenten werkzaam in de openbare apotheek, 2001

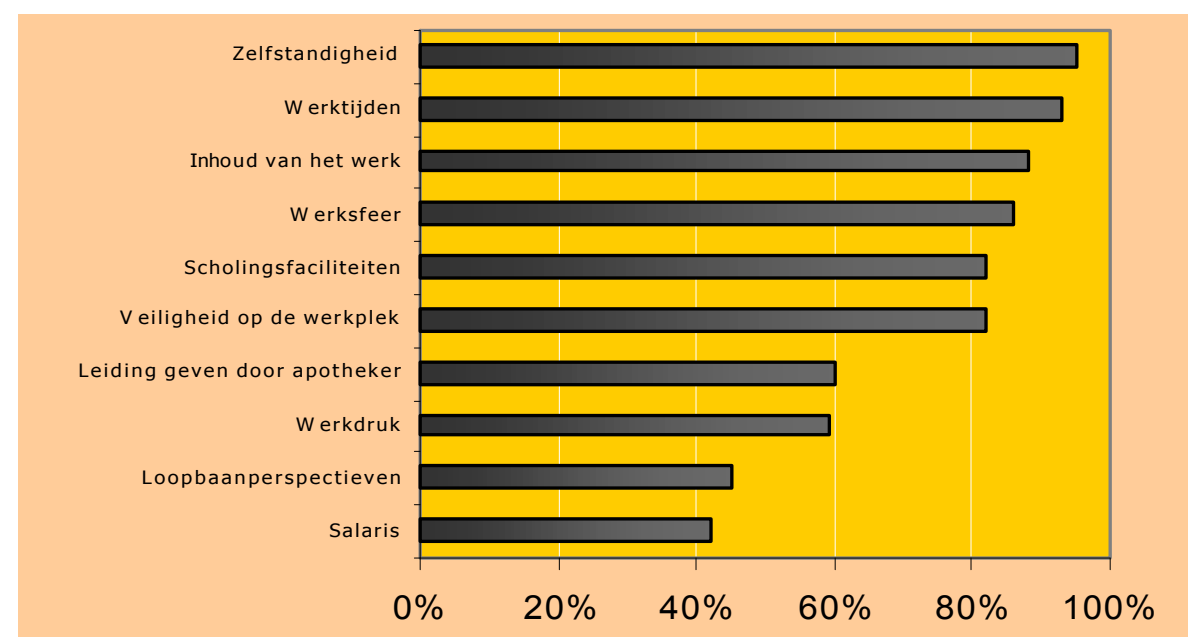

Bron: ROA

Ook over de verschillende aspecten van hun werk zijn apothekersassistenten in de openbare apotheek (zeer) tevreden. Figuur 3.5 laat zien dat assistenten met name over de zelfstandigheid, de werktijden, de inhoud van het werk en de werksfeer zeer te spreken zijn. Wat minder tevreden zijn apothekersassistenten over de wijze van leidinggeven door de apotheker en de werkdruk. Over de loopbaanperspectieven en het salaris is men het meest ontevreden. Ongeveer $40 \%$ van de apothekersassis- 
tenten zegt hierover niet zo tevreden te zijn en nog eens $15 \%$ is er zelfs helemaal niet tevreden mee.

Er is een aantal opvallende verschillen in de tevredenheid van apothekersassistenten te vinden. In de eerste plaats lijken schoolverlaters en herintreders wat tevredener te zijn dan de andere apothekersassistenten. Schoolverlaters zijn alleen wat minder tevreden over de scholingsfaciliteiten, terwijl herintreders wat vaker ontevreden zijn over de werkdruk in de openbare apotheek. De kleine groep apothekersassistenten die een tijdelijk contract zonder uitzicht op een vaste baan heeft, is duidelijk minder tevreden met hun werk, met name wat betreft de zelfstandigheid, de inhoud van het werk, de werksfeer en de scholingsfaciliteiten. Wellicht wordt deze groep (tijdelijk) door apothekers ingeschakeld om de grote pieken op te vangen en moeten zij daarom het minst leuke en het minst uitdagende werk verrichten. Voor het imago van het werken in de openbare apotheek is dit waarschijnlijk geen goede zaak. Verder valt op dat de jongste en de oudste apothekersassistenten meer tevreden zijn over de loopbaanperspectieven en het salaris dan assistenten in de leeftijd van 25 tot 55 jaar. Ten slotte blijkt dat apothekersassistenten met kleine kinderen (0-2 jaar) minder tevreden zijn over hun werktijden. Al eerder zagen we dat deze assistenten net zo vaak meedraaien in onregelmatige en weekend en avonddiensten als assistenten zonder kinderen. Blijkbaar levert dit voor deze groep apothekersassistenten toch spanningen op bij het combineren van het werk met hun zorgtaken.

Tussen de grote en kleine apotheken zijn er enkele verschillen in de mate van tevredenheid van apothekersassistenten. Assistenten die in kleine apotheken werkzaam zijn, geven aan wat ontevredener te zijn over de aangeboden scholingsfaciliteiten. Toch volgen deze apothekersassistenten niet minder cursussen dan assistenten uit grotere apotheken (zie hoofdstuk 4 van dit rapport). Ook de veiligheid op de werkplek wordt minder positief beoordeeld door assistenten uit kleine apotheken. Bovendien bestaan er kleine regionale verschillen in de tevredenheid van assistenten. Apothekersassistenten in de regio Oost Nederland zijn over het algemeen het meest tevreden met de verschillende aspecten van hun werk, met name wat de werkdruk, de veiligheid op de werkplek, de werksfeer en het salaris betreft. Assistenten in de regio Zuidwest Nederland zijn over deze zaken juist minder tevreden, met uitzondering van het salaris, waar ze weer meer tevreden over zijn dan apothekersassistenten in de rest van Nederland.

Als laatste werd aan apothekersassistenten gevraagd hoe tevreden ze zijn over het gevoerde personeels- en arbeidsvoorwaardenbeleid in de openbare apotheek. De eerste kolom in tabel 3.7 laat zien hoe populair de door hun werkgever aangeboden regelingen en faciliteiten zijn. Bijna alle apothekersassistenten worden betrokken bij het werkoverleg (95\%). Ook maken veel assistenten gebruik van de spaarloonregeling (84\%). Functioneringsgesprekken worden met $67 \%$ van de apothekersassistenten gevoerd. Bijna de helft van de assistenten krijgt een reiskostenvergoeding, extra beloning voor het volgen van een cursus of extra kleedgeld. Het minst wordt gebruik gemaakt van het fietsenplan $(23 \%)$, het PC privé project $(20 \%)$ en de aanvullingen op de kinderopvang CAO (12\%). 
Tabel 3.7

Gebruik van en tevredenheid met verschillende aspecten van het personeels- en arbeidsvoorwaardenbeleid van apothekersassistenten werkzaam in de openbare apotheek, 2001

\begin{tabular}{lcc}
\hline $\begin{array}{l}\text { Aspect van personeels- en } \\
\text { arbeidsvoorwaardenbeleid }\end{array}$ & $\begin{array}{c}\text { Maakt gebruik van } \\
\text { aspect } \\
\%\end{array}$ & $\begin{array}{c}\text { Zeer) tevreden } \\
\text { met aspect } \\
\%\end{array}$ \\
\hline & & 63 \\
Werkoverleg & 95 & 97 \\
Spaarloonregeling & 84 & 54 \\
Functioneringsgesprekken & 67 & 80 \\
Flexibele werktijden & 53 & 80 \\
Reiskostenvergoeding & 49 & 38 \\
Extra beloning voor succesvol afronden cursus & 47 & 73 \\
Extra kleedgeld & 46 & 28 \\
Prestatiebeloning & 32 & 60 \\
Leeftijdsbewust personeelsbeleid & 31 & 76 \\
Verlofsparen & 30 & 49 \\
Verzuimbegeleiding & 28 & 57 \\
Persoonlijk ontwikkelingsplan (POP) & 24 & 56 \\
Bedrijfsontwikkelingsplan (BOP) & 23 & 62 \\
Fietsenplan & 23 & 64 \\
PC privé project & 20 & 71 \\
Aanvullingen op kinderopvang CAO & 12 & \\
\end{tabular}

Bron: ROA

Herintreders maken duidelijk minder vaak aanspraak op de aangeboden regelingen en faciliteiten dan de overige apothekersassistenten, met name wat de spaarloonregeling, reiskostenvergoeding, extra beloning voor het succesvol afronden van een cursus en aanvullingen op de kinderopvang CAO betreft. Ook apothekersassistenten die volgens een tijdelijk contract of op oproepbasis werken maken minder gebruik van zaken als spaarloonregeling, extra kleedgeld en extra beloning voor het afronden van een cursus dan assistenten met een vast contract. Assistenten werkzaam in apotheken die zijn aangesloten bij een keten of maatschap met meer dan 5 apotheken beschikken daarentegen vaker over extra kleedgeld, en maken vaker gebruik van een PC privé project en een fietsenplan. Er zijn ook enkele regionale verschillen in het personeels- en arbeidsvoorwaardenbeleid te vinden. Apothekersassistenten in de regio's Zuidwest en Zuidoost Nederland hebben minder vaak te maken met werkoverleg, functioneringsgesprekken en een extra beloning voor het succesvol afronden van een cursus dan assistenten in de rest van Nederland.

De meeste aspecten van het personeels- en arbeidsvoorwaardenbeleid in de openbare apotheek worden als vrij positief ervaren. Zo is $97 \%$ van de apothekersassistenten in de openbare apotheek die gebruik maken van de spaarloonregeling daar (zeer) tevreden over. Eveneens (zeer) tevreden zijn assistenten over de flexibele werktijden $(80 \%)$, de reiskostenvergoeding $(80 \%)$ en het extra kleedgeld $(73 \%)$. Minder tevreden zijn zij over de extra beloning voor het succesvol afronden van een cursus en over de prestatiebeloning. ${ }^{22}$ Maar liefst de helft van de apothekersassistenten die met prestatiebeloning te maken heeft is hierover niet tevreden. Prestatiebeloning wordt overigens niet alleen negatief beoordeeld, het heeft ook een negatief

22. Wat deze prestatiebeloning precies inhoudt, is niet nader gevraagd. 
effect op het ziekteverzuim in de openbare apotheek, zoals uit het werkgeversonderzoek blijkt.

Schoolverlaters zijn over het algemeen meer tevreden over het personeelsbeleid en het arbeidsvoorwaardenbeleid dan de overige apothekersassistenten. Opvallend is dat naarmate men meer werkervaring heeft, men minder tevreden is over het personeelsbeleid in de openbare apotheek. Het gaat dan om zaken als werkoverleg, functioneringsgesprekken, prestatiebeloning, leeftijdsbewust personeelsbeleid, verzuimbegeleiding, een persoonlijk ontwikkelingsplan en een bedrijfsontwikkelingsplan. Apothekersassistenten met meer dan 30 jaar werkervaring vormen echter een uitzondering; zij zijn juist weer meer tevreden over de genoemde aspecten. Waarschijnlijk gaat het hier om een zeer selectieve groep assistenten, omdat assistenten die minder tevreden waren met het personeelsbeleid van hun werkgever vaak geen 30 jaar als apothekersassistent zullen blijven werken. Over het algemeen blijft het beeld bestaan dat assistenten met meer werkervaring kritischer staan tegenover het gevoerde personeelsbeleid in de openbare apotheek. Wellicht is het voor apothekers moeilijk om jaren achtereen de dynamiek in het personeelsbeleid te houden en dit steeds aan te passen aan de in de tijd veranderende wensen van de assistenten. Regionale verschillen hebben met name betrekking op de regio Zuidoost Nederland, waar assistenten over het algemeen wat ontevredener zijn over het werkoverleg, functioneringsgesprekken, prestatiebeloning en het bedrijfsontwikkelingsplan. 


\section{Competentieontwikkeling}

\subsection{Inleiding}

In de laatste drie hoofdstukken van dit rapport staat de employability van apothekersassistenten centraal. Employability wordt gezien als het in staat zijn en de wens hebben om blijvend aantrekkelijk te zijn voor de arbeidsmarkt door te reageren en te anticiperen op veranderingen in arbeidstaken en werkomgeving. ${ }^{23}$ Eén van de mogelijkheden voor werknemers om hun employability te vergroten is het volgen van aanvullende scholing. Door het deelnemen aan opleidingen, trainingen en cursussen kunnen werknemers beter inspelen op demografische, technologische, organisatorische en economische ontwikkelingen die voor veranderingen op de arbeidsmarkt zorgen. ${ }^{24}$ Scholing zorgt ervoor dat werknemers hun competenties verbeteren, kwalificatieveroudering tegengaan en hun arbeidsmarktpositie versterken. Dit geldt zowel voor meer algemene scholing als voor sectorspecifieke scholing.

Dit hoofdstuk handelt over de competentieontwikkeling van apothekersassistenten in de openbare apotheek. In paragraaf 4.2 worden eerst de competenties van de apothekersassistenten in kaart gebracht. Over welke algemene en sectorspecifieke kennis en vaardigheden beschikken zij? Hoe denken zij deze competenties het beste op peil te kunnen houden en zijn zij bereid om een cursus of training te volgen? Paragraaf 4.3 onderzoekt in hoeverre apothekersassistenten in de openbare apotheek aan cursussen deelnemen. Er wordt beschreven welke cursussen zij gevolgd hebben en waarom. In paragraaf 4.4 ten slotte komt de relatie tussen cursusparticipatie en het competentieniveau van de assistenten aan bod. Zijn de competenties van apothekersassistenten die cursussen gevolgd hebben beter dan die van assistenten die dit niet gedaan hebben? En in welke mate kan de opgedane kennis in het werk in de openbare apotheek gebruikt worden?

\subsection{Competenties}

Apothekersassistenten in de openbare apotheek moeten over verschillende competenties beschikken om hun taken goed te verrichten. Deze kennis en vaardigheden kunnen meer algemeen van aard zijn, zoals communicatieve vaardigheden en omgangskunde, zelfstandigheid en omgaan met collega's. Daarnaast zijn meer sectorspecifieke competenties als geneesmiddelenkennis en recepteren en bereiden van geneesmiddelen van belang.

Tabel 4.1 geeft aan hoe apothekersassistenten in de openbare apotheek hun eigen competenties beoordelen. Hieruit blijkt dat assistenten een dikke voldoende scoren wat hun kennis en vaardigheden betreft. Uit het werkgeversonderzoek, waar de apothekers de competenties van de bij hen werkzame assistenten beoordeelden,

23. Grip, A. de, J. van Loo en J. Sanders (1999). Employability in bedrijf: naar een Employability Index voor bedrijfssectoren. ROA-R-1998/10, Maastricht.

24. Grip, A. de, J. van Loo en M. de Steur (1999). Scholing van werkenden. Themarapport Werkgelegenheid en scholing 1998. ROA-R-1999/3, Maastricht. 
kwam hetzelfde beeld naar voren. ${ }^{25}$ De algemene competenties worden hierbij wat hoger ingeschat dan de sectorspecifieke competenties (7,8 versus 7,2$)$. Het slechtst scoren de assistenten volgens henzelf op de sectorspecifieke competentie 'kennis van ziektebeelden' $(6,7)$. Het aantal assistenten dat zichzelf een onvoldoende geeft op deze competentie is echter laag $(6 \%)$.

Tabel 4.1

Zelfbeoordeling van competenties van apothekersassistenten werkzaam in de openbare apotheek (Tienpuntsschaal: 1=afwezig, 10=uitmuntend), 2001

\begin{tabular}{lccc}
\hline & $\begin{array}{c}\text { School- } \\
\text { verlaters }\end{array}$ & $\begin{array}{c}\text { Herintre- } \\
\text { ders }\end{array}$ & Totaal \\
\hline Algemene competenties & 7,8 & 7,6 & 7,8 \\
Computervaardigheden & 7,8 & 7,4 & 7,4 \\
Communicatieve vaardigheden en omgangskunde & 7,5 & 7,2 & 7,7 \\
Zelfstandigheid & 7,7 & 7,7 & 8,0 \\
Omgaan met verantwoordelijkheid & 7,8 & 7,9 & 8,1 \\
Omgaan met collega's & 8,1 & 7,9 & 8,0 \\
Sectorspecifieke competenties & 7,2 & 6,9 & 7,2 \\
Geneesmiddelenkennis & 7,0 & 7,2 & 7,2 \\
Informatieverstrekking over geneesmiddelen & 7,0 & 7,1 & 7,1 \\
Recepteren van geneesmiddelen & 7,7 & 7,7 & 7,7 \\
Bereiden van geneesmiddelen & 7,6 & 7,1 & 7,5 \\
Kennis van ziektebeelden & 6,6 & 6,5 & 6,7 \\
\hline
\end{tabular}

Bron: ROA

Tabel 4.1 laat verder zien dat schoolverlaters hun algemene competenties als 'communicatieve vaardigheden en omgangskunde', 'zelfstandigheid' en 'omgaan met verantwoordelijkheid' wat minder hoog inschatten. Aangenomen mag worden dat deze kennis en vaardigheden moeilijker op school aangeleerd kunnen worden en dat zij tijdens het werken verder ontwikkeld moeten worden. Schoolverlaters zijn echter beduidend beter in 'computervaardigheden' dan de andere assistenten. Herintreders scoren op bijna alle competenties wat lager, zowel wat de algemene als de meer sectorspecifieke competenties betreft. Met name op het terrein van 'communicatieve vaardigheden en omgangskunde' en 'het bereiden van geneesmiddelen' vallen de rapportcijfers van herintreders duidelijk lager uit. Dit duidt op een zekere mate van kwalificatieveroudering. Wellicht was er minder aandacht voor deze aspecten toen zij hun opleiding volgden. Aangezien apothekersassistenten met meer werkervaring hun eigen competenties eveneens lager inschatten, treedt deze kwalificatieveroudering blijkbaar ook op bij deze groep assistenten. Ten slotte is het opvallend dat assistenten werkzaam in een zelfstandige apotheek zichzelf hoger inschatten wat het kunnen 'omgaan met verantwoordelijkheid' betreft. Wellicht krijgen deze assistenten ook

25. Apothekers schatten de competenties van de bij hen werkzame apothekersassistenten over het algemeen - hetzelfde in als de assistenten zelf. Alleen algemene competenties als 'communicatieve vaardigheden', 'zelfstandigheid', 'omgaan met verantwoordelijkheid' en 'omgaan met collega's' worden door de assistenten zelf iets hoger beoordeeld dan door de apothekers. 
meer verantwoordelijkheid dan assistenten uit apotheken die deel uitmaken van een keten of maatschap.

\section{Het op peil houden van competenties}

Aan de apothekersassistenten is vervolgens gevraagd op welke wijze zij denken hun competenties het beste op peil te kunnen houden. Tabel 4.2 laat zien dat de computervaardigheden en communicatieve vaardigheden volgens de meeste assistenten het beste via het leren op de werkplek op peil gehouden kunnen worden. Pas daarna noemen zij het volgen van cursussen en het leren van collega's. Bij de sectorspecifieke competentie 'bereiden van geneesmiddelen' komt hetzelfde beeld naar voren. Ook hier is het leren op de werkplek volgens de assistenten de beste methode is om deze competentie op peil te houden. Zelfstudie wordt door zeer weinig apothekersassistenten genoemd. Geneesmiddelenkennis kan daarentegen beter door het volgen van cursussen op niveau gehouden kunnen worden. Het leren op de werkplek speelt hierbij een beduidend kleinere rol, terwijl het leren van collega's slechts door $2 \%$ van de apothekersassistenten genoemd wordt als de beste manier om hun geneesmiddelenkennis op peil te houden.

Tabel 4.2

Manieren om competenties het beste op peil te kunnen houden volgens apothekersassistenten werkzaam in de openbare apotheek, 2001

\begin{tabular}{|c|c|c|c|c|}
\hline & \multicolumn{2}{|c|}{ Algemene competenties } & \multicolumn{2}{|c|}{ Sectorspecifieke competenties } \\
\hline & $\begin{array}{c}\text { Computer } \\
\text { vaardigheden } \\
\%\end{array}$ & $\begin{array}{c}\text { Communicatieve } \\
\text { vaardigheden } \\
\%\end{array}$ & $\begin{array}{c}\text { Bereiden van } \\
\text { geneesmiddelen } \\
\%\end{array}$ & $\begin{array}{c}\text { Geneesmiddelen } \\
\text { kennis } \\
\%\end{array}$ \\
\hline $\begin{array}{l}\text { Zelfstudie } \\
\text { Cursussen volgen } \\
\text { Leren op werkplek } \\
\text { Leren van collega's }\end{array}$ & $\begin{array}{r}7 \\
20 \\
56 \\
17\end{array}$ & $\begin{array}{r}6 \\
16 \\
66 \\
12\end{array}$ & $\begin{array}{r}3 \\
15 \\
68 \\
15\end{array}$ & $\begin{array}{r}11 \\
59 \\
28 \\
2\end{array}$ \\
\hline
\end{tabular}

Opvallend is dat schoolverlaters vaker dan andere assistenten aangeven dat het leren van collega's de beste manier is om hun competenties op peil te houden. Dit geldt zowel voor de algemene competenties als voor de meer sectorspecifieke kennis en vaardigheden. Ook herintreders vinden dit vaak een goede methode, maar dan met name voor computervaardigheden en het bereiden van geneesmiddelen. Het volgen van cursussen om deze twee competenties op peil te houden wordt door schoolverlaters veel minder vaak als de beste manier gezien. Ten slotte blijken er enkele regionale verschillen te bestaan. Apothekersassistenten in de regio Zuidwest Nederland zien wat minder in het leren op de werkplek en van collega's en wat meer in het volgen van cursussen, terwijl assistenten in de regio's Noord en Zuidoost Nederland juist meer vertrouwen hebben in het leren op de werkplek en van collega's en minder in het volgen van cursussen.

Overigens laat figuur 4.1 zien dat maar liefst 95\% van de apothekersassistenten in de openbare apotheek bereid is om een cursus te volgen wanneer de apotheker 
daarom vraagt. Deze bereidheid neemt wel af met het aantal jaren dat men al als apothekersassistent werkzaam is. Van de assistenten die meer dan 30 jaar werkervaring hebben, is nog maar $85 \%$ bereid om een cursus te volgen.

Zeer opvallend is dat het competentieniveau van apothekersassistenten in de openbare apotheek op geen enkele wijze samenhangt met hun bereidheid om een cursus te gaan volgen. Minder competente assistenten tonen dus niet meer bereidheid om een cursus te gaan volgen dan de meer competente assistenten.

Figuur 4.1

Bereidheid om een cursus te volgen van apothekersassistenten werkzaam in de openbare apotheek, 2001

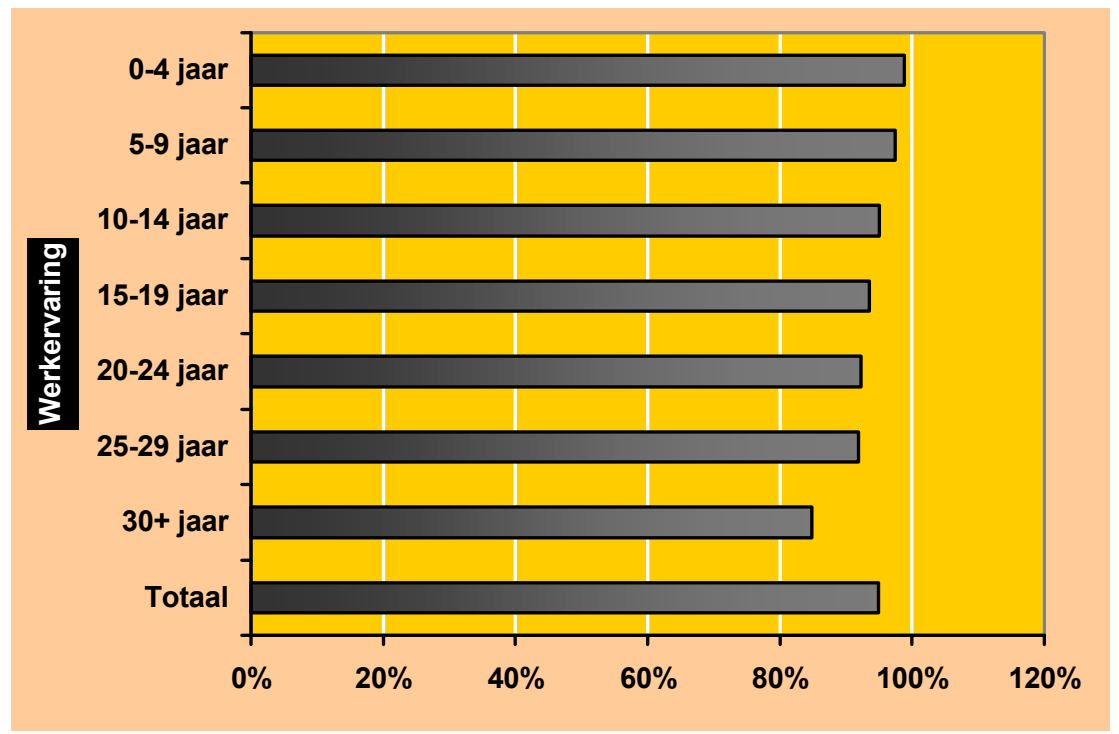

Bron: ROA

\subsection{Participatie in cursussen}

Hoeveel apothekersassistenten nemen nu jaarlijks aan een cursus deel? Uit tabel 4.3 blijkt dat $64 \%$ van de assistenten in 2001 één of meerdere cursussen gevolgd heeft. Vergeleken met andere bedrijfssectoren in Nederland is dit is een zeer hoog percentage. In de zorgsector bijvoorbeeld volgde slechts $47 \%$ van de werkenden een cursus. ${ }^{26}$ Schoolverlaters participeren wat vaker in cursussen $(74 \%)$, hetgeen in overeenstemming is met de bevinding in de literatuur dat werknemers die pas starten in een nieuwe baan meer scholing volgen. ${ }^{27}$ Herintreders daarentegen volgen opmerkelijk genoeg wat minder vaak cursussen $(60 \%)$. Hun werkervaring speelt hierbij zeker een rol, zoals ook blijkt uit het feit dat met name apothekersassistenten die minder

26. G. van Essen, H.E. Meihuizen en F. Peters (2001). Arbeid in Zorg en Welzijn. Integrerend OSA-rapprt 2001. OSA-publicatie ZW20, Tilburg.

27. F. Green (1993). The Determinants of Training Male and Female Employees in Britain. Oxford Bulletin of Economics and Statistics, 55: 103-122. 
dan 10 jaar werkervaring hebben de meeste cursussen volgen. Daarna neemt de cursusparticipatie af. Assistenten die meer dan 30 jaar werkervaring hebben, nemen het minst aan cursussen deel (47\%). Wellicht zijn deze ervaren assistenten van

Tabel 4.3

Participatie in één of meerdere cursussen in 2001 door apothekersassistenten werkzaam in de openbare apotheek, naar kenmerken van assistenten en apotheken, 2001

\begin{tabular}{|c|c|}
\hline & $\begin{array}{c}\text { Participatie in cursussen } \\
\%\end{array}$ \\
\hline $\begin{array}{l}\text { Soort apothekersassistent } \\
\text { Schoolverlaters } \\
\text { Herintreders }\end{array}$ & $\begin{array}{l}73 \\
60\end{array}$ \\
\hline $\begin{array}{l}\text { Werkervaring als apothekersassistent } \\
\text { Minder dan } 5 \text { jaar } \\
5-9 \text { jaar } \\
10-14 \text { jaar } \\
15-19 \text { jaar } \\
20-24 \text { jaar } \\
25-29 \text { jaar } \\
30 \text { jaar of meer }\end{array}$ & $\begin{array}{l}77 \\
71 \\
58 \\
58 \\
61 \\
62 \\
47\end{array}$ \\
\hline $\begin{array}{l}\text { Werkuren per week } \\
\text { Minder dan } 20 \text { per week } \\
20 \text { tot } 32 \text { uur per week } \\
32 \text { tot } 36 \text { uur per week } \\
36 \text { uur per week of meer }\end{array}$ & $\begin{array}{l}46 \\
61 \\
67 \\
78\end{array}$ \\
\hline $\begin{array}{l}\text { Soort apotheek } \\
\text { Zelfstandige apotheek } \\
\text { Keten of maatschap van minder dan } 5 \text { apotheken } \\
\text { Keten of maatschap van } 5 \text { apotheken of meer }\end{array}$ & $\begin{array}{l}65 \\
73 \\
73\end{array}$ \\
\hline $\begin{array}{l}\text { Regio } \\
\text { Noord Nederland } \\
\text { Oost Nederland } \\
\text { Noordwest Nederland } \\
\text { Middenwest Nederland } \\
\text { Zuidwest Nederland } \\
\text { Zuidoost Nederland }\end{array}$ & $\begin{array}{l}76 \\
68 \\
62 \\
61 \\
66 \\
54\end{array}$ \\
\hline Totaal & 64 \\
\hline
\end{tabular}

\section{Bron: ROA}

mening dat het volgen van een cursus voor hen minder nuttig is, omdat het aantal jaren dat zij nog in de apotheek zullen werken gering is. Verder blijken fulltime werkende assistenten veel vaker deel te nemen aan cursussen dan parttimers. Van de apothekersassistenten die minder dan 20 uur per week werken volgt maar $46 \%$ een cursus, tegenover $78 \%$ van de fulltime werkende assistenten. In de literatuur wordt deze bevinding vaak verklaard door te wijzen op het lagere rendement van de scholing van parttimers, waardoor het langer duurt voordat de investeringen in training terugverdiend zijn. ${ }^{28}$ Aan de andere kant is het ook zo dat parttimers - juist

28. R. Kunnen en M. De Voogd-Hamelink (1997). Scholingsgedrag in Nederland 1986-1992. Den Haag: OSA. 
omdat zij minder uren werken en naast hun werk vaak nog zorgtaken hebben minder werktijd over hebben om aan cursussen deel te nemen. ${ }^{29}$

29. ROA (2002). Werkgelegenheid en scholing 2001. ROA-R-2002/7, Maastricht. 
De omvang van de apotheek blijkt geen invloed op de cursusparticipatie van apothekersassistenten te hebben. Wel zijn er verschillen tussen diverse soorten apotheken te vinden. Assistenten die werkzaam zijn in apotheken die deel uitmaken van een keten of maatschap nemen meer aan cursussen deel dan assistenten die in zelfstandige apotheken werken. Ten slotte zijn er enkele opvallende regionale verschillen. Maar liefst $76 \%$ van de apothekersassistenten in de regio Noord Nederland heeft in 2001 een cursus gevolgd, tegenover slechts $54 \%$ in de regio Zuidoost.

\section{Figuur 4.2}

Participatie in cursussen in 2001 door apothekersassistenten werkzaam in de openbare apotheek, 2001

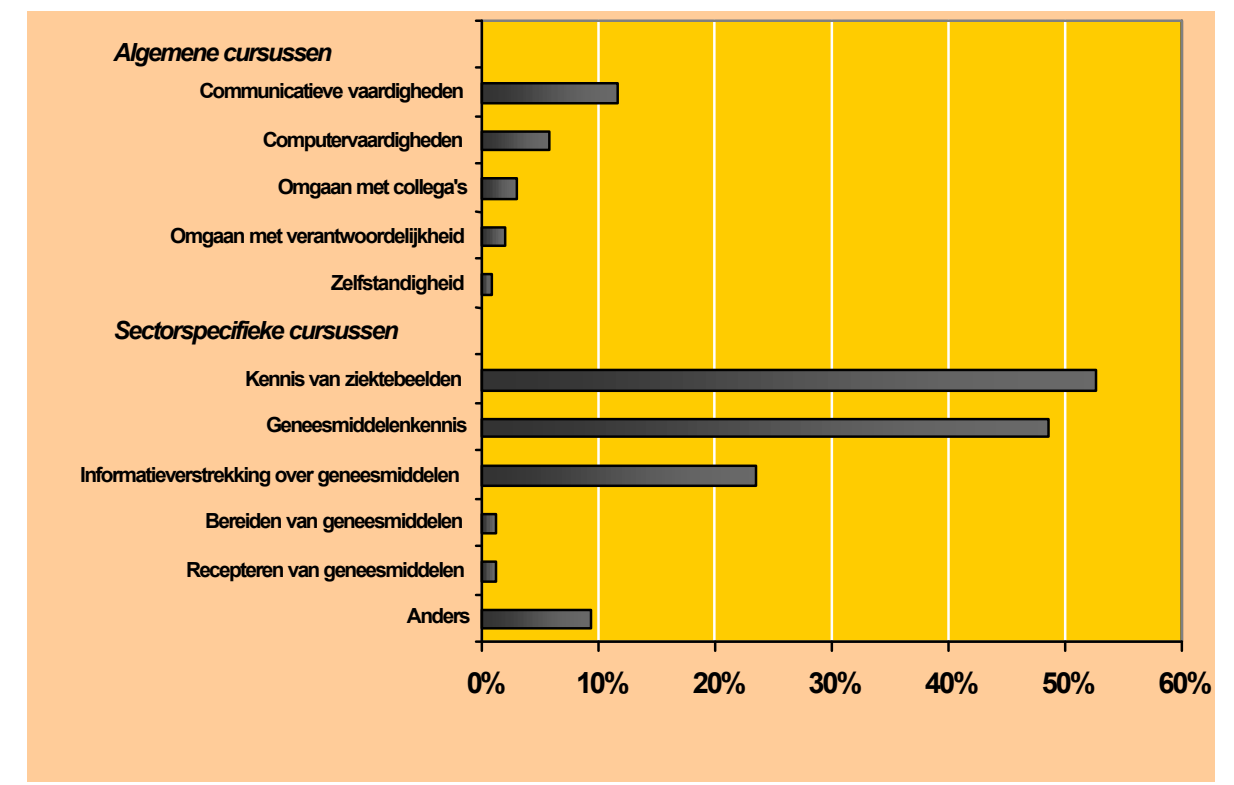

Bron: ROA

Welke cursussen volgden de apothekersassistenten? In de werknemersenquête is aan assistenten gevraagd aan te geven op welke terrein de laatst gevolgde cursus lag. ${ }^{30}$ Figuur 4.2 laat zien dat de sectorspecifieke cursussen het meest populair zijn. Met name aan cursussen op het gebied van kennis van ziektebeelden $(53 \%)$ en geneesmiddelenkennis (49\%) wordt veel deelgenomen. Het is opvallend dat deze cursussen minder vaak gevolgd worden door oudere werknemers, assistenten met meer werkervaring en herintreders. De participatie van apothekersassistenten in algemene cursussen is veel minder groot dan de deelname aan sectorspecifieke cursussen. Hier zijn cursussen op het terrein van de communicatieve vaardigheden het meest populair (12\%). Deze cursussen worden door schoolverlaters overigens veel vaker gevolgd dan door andere assistenten. Ongeveer $6 \%$ van de apothekersassistenten die in 2001 een cursus volgden, nam deel aan een computercursus.

30. Om de respondenten niet te veel te belasten, is er slechts naar één cursus (de laatst gevolgde) gevraagd. Dit is een veelgebruikte methode, die over het algemeen een goed beeld geeft van de cursusparticipatie. 
Deze computercursussen hebben overigens lang niet altijd een brede opzet. Vaak zijn ze zeer specifiek omdat ze gericht zijn op het leren omgaan met een bepaald computerprogramma. Hierbij zijn de assistenten uit de apotheken die deel uitmaken van een keten of maatschap van meer dan 5 apotheken oververtegenwoordigd. Uit het werkgeversonderzoek blijkt dat met name in deze apotheken vaak recentelijk een nieuw computersysteem in gebruik is genomen. Assistenten krijgen dan vaak een cursus aangeboden om zich dit programma eigen te maken. Een klein deel van de apothekersassistenten ( $9 \%$ ) heeft nog andere cursussen gevolgd. Het gaat dan bijvoorbeeld om cursussen medicatiebegeleiding of bewaking, cursussen bedrijfshulpverlening, managementcursussen en cursussen drogist of cosmetica.

Ten slotte bestaan er ook enkele regionale verschillen. Apothekersassistenten in de Randstad volgen veel minder vaak een cursus gericht op het verbeteren van hun geneesmiddelenkennis. Waarschijnlijk heeft dit voor een deel te maken met het feit dat assistenten in de Randstad gemiddeld wat ouder zijn, en dat oudere werknemers deze cursus minder vaak volgen. In de regio's Oost en Zuidwest Nederland wordt vaker deelgenomen aan een cursus 'kennis van ziektebeelden' dan in de regio's Noord en Zuidoost Nederland. Het is aannemelijk dat deze regionale verschillen voor een deel veroorzaakt worden door het verschillende aanbod van cursussen in de diverse regio's.

\section{Figuur 4.3}

Betaling van door apothekersassistenten werkzaam in de openbare apotheek in 2001 gevolgde cursussen, 2001

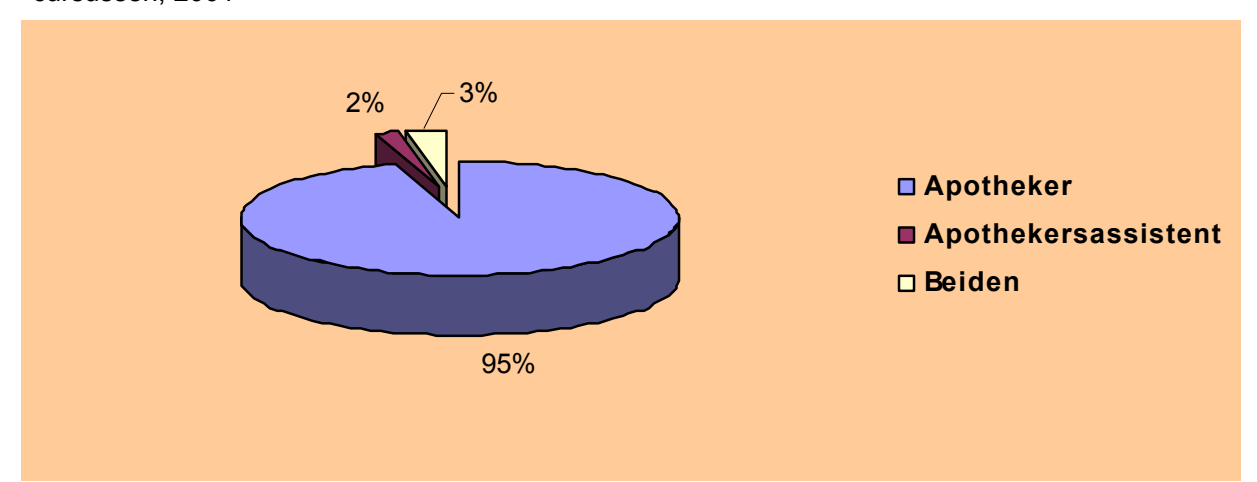

Bron: ROA

\section{Cursuskosten}

De werkgever betaalt bijna altijd de kosten van de cursussen. Figuur 4.3 geeft aan dat de apothekersassistenten slechts in $2 \%$ van de gevallen de cursussen zelf betalen en in 3\% samen met de apotheker de kosten voor hun rekening nemen. Dit patroon is bij alle cursussen terug te vinden. Alleen cursussen op het terrein van het recepteren van geneesmiddelen en 'zelfstandigheid' worden iets minder vaak door de apotheker betaald (respectievelijk $91 \%$ en $88 \%$ ). Verschillen tussen zelfstandige en niet-zelfstandige apotheken en regionale verschillen worden niet gevonden. Wel is het zo dat assistenten die in kleine apotheken werken wat vaker (een deel van) de kosten van een cursus voor hun rekening nemen dan assistenten in grote apotheken. 
Uit het werkgeversonderzoek blijkt overigens dat het initiatief om een cursus te volgen meestal door apotheker en apothekersassistent samen genomen wordt.

\section{Redenen om cursussen te volgen}

Waarom worden er door apothekersassistenten cursussen gevolgd? Volgens de assistenten zelf is dit met name om bij te blijven: $42 \%$ van hen noemt dit als belangrijkste reden om aan een cursus deel te nemen (zie tabel 4.4). Daarnaast worden het zich verder specialiseren (20\%) en het wegwerken van een tekort aan kennis en vaardigheden (16\%) vaak als reden opgegeven. Opvallend is ook dat $13 \%$ van de assistenten de aan de cursus gekoppelde salarisverhoging noemt. Wanneer de gevolgde cursussen door de SBA geaccrediteerd zijn, leveren ze de apothekersassistenten studiepunten op. In Artikel 7 van de CAO Apotheken is vastgelegd dat apothekersassistenten werkzaam in de openbare apotheek een salarisschaal stijgen wanneer ze door nascholing een totaal van 120 studiepunten behaald hebben. ${ }^{31}$ Uit het werkgeversonderzoek blijkt dat $56 \%$ van de gevolgde cursussen door de SBA geaccrediteerd zijn.

Tabel 4.4

Belangrijkste redenen om cursussen te volgen volgens apothekersassistenten werkzaam in de openbare apotheek, 2001

\begin{tabular}{lccc}
\hline & $\begin{array}{c}\text { Schoolverlaters } \\
\%\end{array}$ & $\begin{array}{c}\text { Herintreders } \\
\%\end{array}$ & $\begin{array}{c}\text { Totaal } \\
\%\end{array}$ \\
\hline Bijblijven & 17 & 41 & 42 \\
Zich verder specialiseren & 34 & 13 & 20 \\
Wegwerken van tekort aan kennis en vaardigheden & 23 & 34 & 16 \\
Salarisverhoging & 17 & 5 & 13 \\
Verplichte cursus & 6 & 6 & 5 \\
Promotie kunnen maken & 0 & 1 & 1 \\
Ander werk kunnen doen & 1 & 0 & 2 \\
Anders & 3 & 1 & \\
Bron: ROA & & & \\
\hline
\end{tabular}

Tabel 4.4 laat ook enkele opvallende verschillen tussen schoolverlaters, herintreders en andere apothekersassistenten zien. Schoolverlaters geven als belangrijkste reden om een cursus te volgen op dat zij zich verder willen specialiseren. Herintreders geven veel vaker aan dat zij door het deelnemen aan een cursus willen bijblijven en tekorten in kennis en vaardigheden willen wegwerken. Opvallend is dat voor herintreders de aan de cursus gekoppelde salarisverhoging veel minder vaak de belangrijkste reden is om een cursus te gaan volgen; slechts $5 \%$ van hen noemt dit als de belangrijkste reden. Ook assistenten met meer werkervaring noemen de salarisverhoging beduidend minder vaak als de belangrijkste reden. Zij volgen met name cursussen om bij te blijven, en minder vaak om zich verder te specialiseren of een tekort aan kennis en vaardigheden weg te werken. Er zijn geen verschillen te vinden tussen zelfstandige en niet-zelfstandige apotheken, tussen kleine en grote apotheken of tussen regio's. 
De reden om een cursus te volgen verschilt overigens wel per cursus. Zo worden de algemene cursussen 'omgaan met collega's', communicatieve vaardigheden en 'zelfstandigheid' vaak gevolgd omdat ze verplicht zijn. Voor het deelnemen aan cursussen op de terreinen 'recepteren van geneesmiddelen' en 'omgaan met verantwoordelijkheid' wordt daarentegen veelal het zich willen specialiseren als belangrijkste reden genoemd. De aan de cursus gekoppelde salarisverhoging speelt met name bij de cursussen gericht op het verbeteren van iemands 'zelfstandigheid' een rol, en is bijna niet van belang voor de cursussen computervaardigheden en 'omgaan met collega's'. Dit heeft voor een groot deel te maken met het aantal studiepunten dat op basis van studiebelasting - aan de verschillende cursussen wordt toegekend.

\section{Figuur 4.4}

Gemiddeld aantal studiepunten van de laatst gevolgde cursus door apothekersassistenten werkzaam in de openbare apotheek, 2001

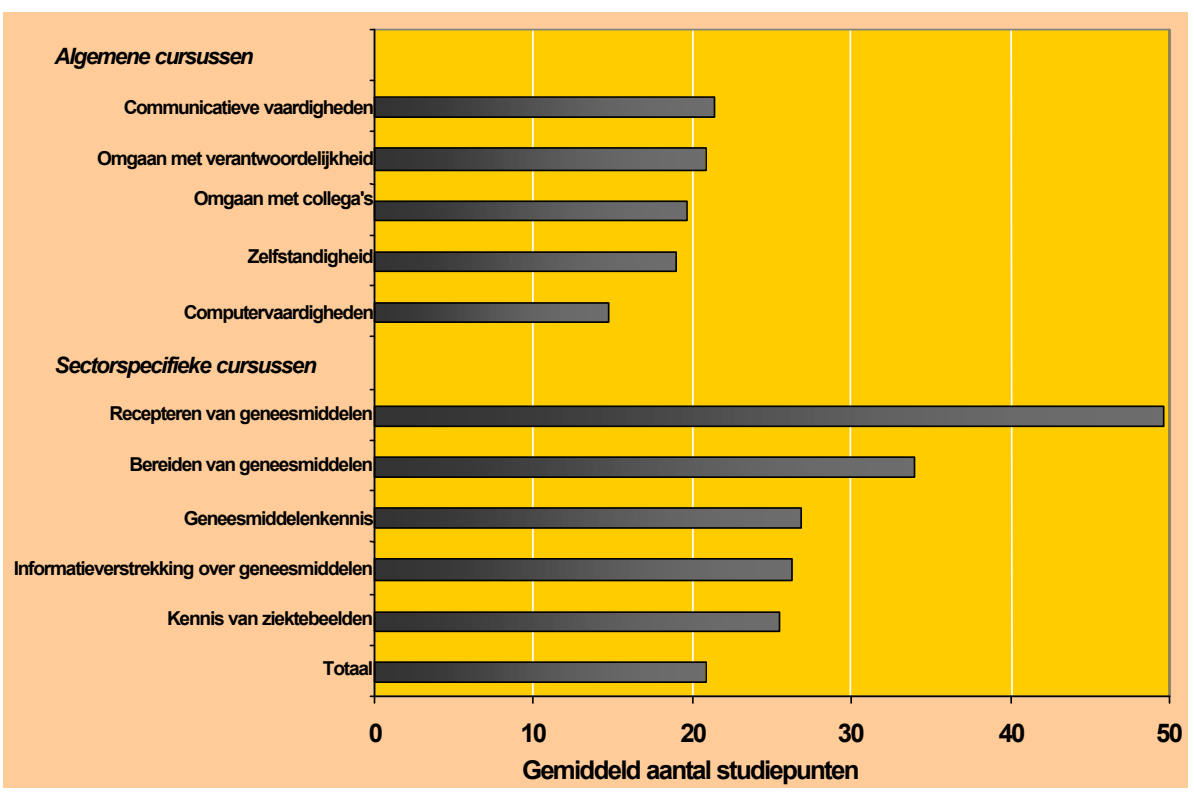

Bron: ROA

Zo laat figuur 4.4 zien dat een cursus gemiddeld 21 studiepunten oplevert. Met name door sectorspecifieke cursussen op het gebied van 'recepteren van geneesmiddelen' en 'bereiden van geneesmiddelen' te volgen, verdienen apothekersassistenten veel studiepunten. ${ }^{32}$ Aan algemene cursussen worden minder studiepunten toegekend. Zo levert een cursus computervaardigheden gemiddeld slechts 15 studiepunten op. Overigens heeft $22 \%$ van de assistenten helemaal geen studiepunten gekregen voor de door hen laatst gevolgde cursus. In de regio Zuidoost Nederland worden gemid-

32. Op het eerste gezicht lijken deze cursussen zeer aantrekkelijk voor apothekersassistenten. Ze leveren immers veel studiepunten op, waardoor een salarisverhoging door nascholing eerder bereikt kan worden. Toch heeft slechts $5 \%$ van de assistenten in 2001 een cursus 'recepteren van geneesmiddelen' of 'bereiden van geneesmiddelen' gevolgd. Bovendien geven de meeste apothekersassistenten aan deze cursussen voornamelijk te volgen om zich te specialiseren, en niet om de aan de cursus gekoppelde salarisverhoging. 
deld genomen meer studiepunten verdiend dan in de regio Noord Nederland. Dit is opvallend, aangezien de cursusparticipatie in de regio Zuidoost Nederland het laagst is. Blijkbaar volgen apothekersassistenten in deze regio weinig cursussen, maar kiezen ze daarbij wel voor de cursussen die door de SBA geaccrediteerd zijn en veel studiepunten opleveren.

\subsection{Cursusparticipatie en competentieniveau}

Kunnen apothekersassistenten hun competenties nu verbeteren door cursussen te volgen? Om een antwoord op deze vraag te geven staan in tabel 4.5 de gemiddelde scores op alle competenties vermeld voor assistenten die in 2001 wel een cursus gevolgd hebben en voor assistenten die dit niet gedaan hebben. Uit de tabel blijkt dat met name de sectorspecifieke kennis en vaardigheden van assistenten beter worden door aan cursussen op dat terrein deel te nemen. De verschillen zijn significant, maar klein. Ze blijven bestaan wanneer er gecontroleerd wordt voor belangrijke kenmerken van assistenten en apotheken. De enige uitzondering is het niveau van de competentie 'recepteren van geneesmiddelen'. Dit competentieniveau verschilt niet tussen degenen die een cursus op dat gebied gevolgd hebben en degenen die dat niet gedaan hebben. Hetzelfde geldt voor de cursisten gericht op het verbeteren van algemene competentie. Wel kunnen door het volgen van een cursus computervaardigheden de competenties van assistenten op dit gebied worden opgekrikt.

Tabel 4.5

Gemiddeld competentieniveau na het wel en niet volgen van een cursus op het terrein van die competentie door apothekersassistenten werkzaam in de openbare apotheek, 2001

\begin{tabular}{lcc}
\hline & $\begin{array}{c}\text { Wel cursus } \\
\text { gevolgd }\end{array}$ & $\begin{array}{c}\text { Geen cursus } \\
\text { gevolgd }\end{array}$ \\
\hline Algemene competenties & 7,9 & 7,8 \\
Computervaardigheden & 7,5 & 7,4 \\
Communicatieve vaardigheden en omgangskunde & 7,7 & 7,7 \\
Zelfstandigheid & 8,1 & 8,1 \\
Omgaan met verantwoordelijkheid & 8,0 & 8,1 \\
Omgaan met collega's & 8,0 & 8,0 \\
Sectorspecifieke competenties & & 7,2 \\
Geneesmiddelenkennis & 7,3 & 7,1 \\
Informatieverstrekking over geneesmiddelen & 7,3 & 7,1 \\
Recepteren van geneesmiddelen & 7,2 & 7,7 \\
Bereiden van geneesmiddelen & 7,7 & 7,5 \\
Kennis van ziektebeelden & 8,1 & 6,7 \\
\end{tabular}

Apothekersassistenten met een hoger competentieniveau zullen beter in staat zijn hun functie adequaat uit te oefenen. Wanneer dit hogere niveau verkregen is door het volgen van cursussen, zoals blijkt uit tabel 4.5, dan betekent dit dat deze cursussen vruchten afwerpen. Een tweede manier om na te gaan of de gevolgde cursussen effectief zijn, is door te kijken naar het praktische nut van deze cursussen. Aan de apothekersassistenten is gevraagd of de in de cursussen opgedane kennis van pas komt in het werk in de openbare apotheek. Figuur 4.5 laat zien dat een ruime meerderheid van de assistenten de opgedane kennis bij de eigen werkzaamheden 
gebruikt (58\%). Nog eens $36 \%$ geeft aan dat deze kennis zowel door henzelf als door collega's in de apotheek toegepast wordt. Slechts $5 \%$ van de assistenten die in 2001 een cursus gevolgd hebben laat weten dat de opgedane kennis niet van pas komt in het werk.

\section{Figuur 4.5}

Gebruik van in cursus opgedane kennis in het werk door apothekersassistenten werkzaam in de openbare apotheek, 2001

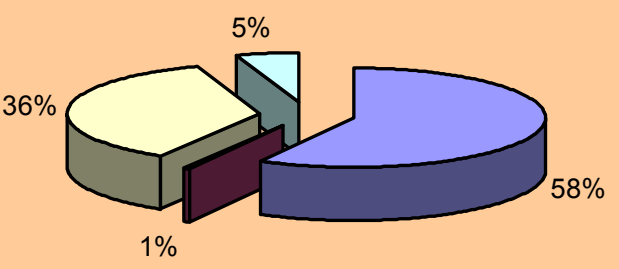

口Door apothekersassistent

口Door collega's

口Door beiden

$\square$ Geen gebruik

Bron: ROA

Er zijn geen verschillen in het gebruik van de in de cursussen opgedane kennis tussen schoolverlaters, herintreders, apothekersassistenten met veel en weinig werkervaring of parttimers en fulltimers gevonden. Ook maakt het niet uit of assistenten werken in zelfstandige apotheken of apotheken die deel uitmaken van een keten of maatschap, in kleine of in grote apotheken, of in de diverse regio's. Wel verschilt het praktische nut per cursusgebied. De kennis die tijdens de sectorspecifieke cursussen op het terrein van geneesmiddelenkennis, informatieverstrekking over geneesmiddelen en kennis van ziektebeelden is opgedaan, wordt slechts door 2 à 3 procent van de assistenten gekenmerkt als niet bruikbaar in het werk. De sectorspecifieke cursussen 'recepteren van geneesmiddelen' en 'bereiden van geneesmiddelen' worden daarentegen als de minst nuttige cursussen beschouwd. Maar liefst één op de zes assistenten vindt dat de in deze cursussen opgedane kennis niet van pas komen in het werk. Opvallend is verder dat de kennis opgedaan in de algemene cursussen 'zelfstandigheid', 'omgaan met verantwoordelijkheid' en 'omgaan met collega's' vaak door zowel de assistent zelf als door de collega's in de apotheek gebruikt wordt. 


\section{Flexibele inzetbaarheid en arbeidsmarkt- perspectieven}

\subsection{Inleiding}

Naast scholing is flexibele inzetbaarheid een tweede instrument om de employability van apothekersassistenten in de openbare apotheek te vergroten. Flexibele inzetbaarheid wordt gekenmerkt door twee dimensies. ${ }^{33}$ De kwantitatieve dimensie heeft betrekking op het aantal uren dat werknemers inzetbaar zijn. De kwalitatieve dimensie heeft te maken met het verrichten van taken die niet tot de functie behoren. Wanneer werknemers zich flexibel opstellen, zowel wat uren als wat taken betreft, zijn ze beter in staat in te spelen op arbeidsmarktveranderingen die ontstaan door demografische, technologische, organisatorische of economische omstandigheden. Ze kunnen zo sneller en beter reageren en anticiperen op veranderingen in arbeidstaken of werkomgeving. Dit verhoogt hun waarde binnen de organisatie, maar ook daarbuiten. Flexibele werknemers hebben over het algemeen meer afwisselende banen, (vaak) hogere salarissen, en een groter vermogen om werk te krijgen en werk te houden. Met andere woorden, ze zijn meer employabel. Werkgevers hebben ook graag flexibele werknemers in dienst, omdat zij een slagvaardig personeelsbestand vormen dat op meerdere uren en taken inzetbaar is. De keerzijde van de medaille is dat flexibele inzetbaarheid vaak gepaard gaat met een hogere werkdruk voor werknemers, hetgeen tot meer ziekteverzuim en zelfs uitstroom kan leiden. Aan deze en andere gevolgen van flexibele inzetbaarheid zal in hoofdstuk 6 aandacht besteed worden.

In dit hoofdstuk wordt de flexibele inzetbaarheid van apothekersassistenten in de openbare apotheek beschreven, zowel op het terrein van hun werktijden als de te verrichten werkzaamheden. We brengen daarbij niet alleen de actuele situatie van assistenten in kaart, maar besteden ook aandacht aan hun bereidheid om flexibel inzetbaar te zijn. ${ }^{34}$ De opbouw van dit hoofdstuk is als volgt. In paragraaf $4.2 \mathrm{komt}$ het overwerken in de openbare apotheek aan de orde. Hoeveel uur werken assistenten buiten hun contract om en in hoeverre zijn zij bereid tot overwerk wanneer de apotheker daarom vraagt? Ook wordt er aandacht besteed aan het aantal uren dat apothekersassistenten het liefst zouden willen werken. In paragraaf 4.3 wordt de tweede, meer kwalitatieve, dimensie van flexibele inzetbaarheid onderzocht. Eerst wordt in kaart gebracht welke werkzaamheden apothekersassistenten verrichten. Daarna wordt nagegaan in hoeverre zij taken uitvoeren die niet tot hun functie behoren, zoals farmaceutische taken van de apotheker, management taken en taken uit andere functies. Ook hun bereidheid om deze taken uit te voeren wordt in beeld gebracht. Paragraaf 4.4 sluit dit hoofdstuk af met een beschrijving van de loopbaan-

33. J.F. Bolweg en J.M.M. Maenhout (1995). Full employability: economisch noodzakelijk, sociologisch naï ef? p. 92-99 in: L. Faase, M. Ott en C.J. Voss (red.). Nieuwe breukvlakken in het arbeidsbestel? De Tijdstroom, Utrecht.

34. Flexibele inzetbaarheid valt zo uiteen in een vermogensaspect en een bereidheidsaspect. Zie: A. de Grip, J. van Loo en M. de Steur (1999). Scholing van werkenden. Themarapport Werkgelegenheid en scholing 1998. ROA-R-1999/3, Maastricht. 
en arbeidsmarktperspectieven van apothekersassistenten binnen en buiten de branche.

\subsection{Overwerk}

Driekwart van de apothekersassistenten in de openbare apotheek houdt zich aan het aantal werkuren dat in hun contract afgesproken is. $13 \%$ Van de assistenten werkt stelselmatig minder uren dan in hun contract staat, waarvan een kwart zelfs meer dan 5 uur per week minder. Overwerk komt echter ook voor in de openbare apotheek. $13 \%$ Van de apothekersassistenten werkt meer uren dan in hun contract staat. Gemiddeld gaat het om zo'n 3 uur per week. Hierbij moet opgemerkt worden dat veel overwerk in de openbare apotheek bestaat uit het draaien van extra diensten op zaterdag. Deze diensten zijn niet in het contract opgenomen, maar verlopen wel volgens een vast patroon. Dit soort overwerk zal mogelijk weinig belasting voor de apothekersassistenten vormen, omdat het vrijwillig overwerk op regelmatige basis betreft. Uit het werkgeversonderzoek blijkt dat het meeste overwerk niet structureel van aard is.

\section{Figuur 5.1}

Overwerk van apothekersassistenten werkzaam in de openbare apotheek, 2001

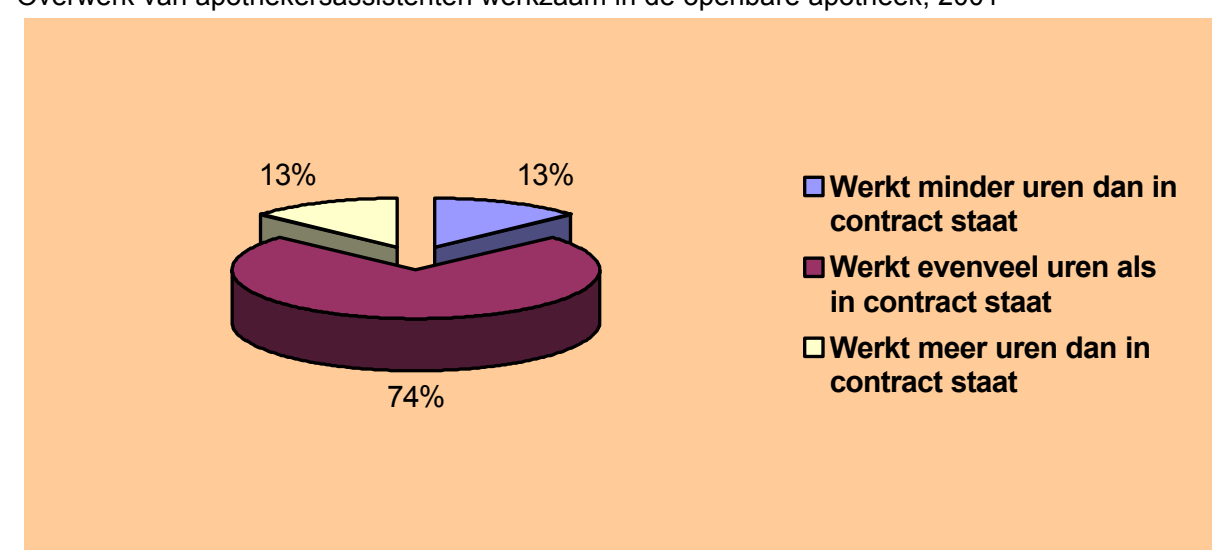

Bron: ROA

Schoolverlaters blijken niet vaker over te werken dan andere apothekersassistenten in de openbare apotheek. Herintreders daarentegen werken veel vaker meer uren dan in hun contract vermeld staat, net als assistenten in de leeftijd van 35 tot 50 jaar. Apothekersassistenten met jonge kinderen werken minder vaak over, wellicht omdat zij hun tijd buiten het werk willen besteden aan zorgtaken. Assistenten met kinderen in de leeftijd van 5 tot 15 jaar werken echter juist vaker over dan andere assistenten. Mogelijk slagen assistenten met schoolgaande kinderen er beter in om werk en zorgtaken te combineren, waardoor zij in staat zijn om meer uren buiten hun contract te werken. Waarschijnlijk spelen bovendien financiële motieven een rol bij de beslissing om overwerk te verrichten. Ten slotte blijken ook assistenten die minder dan 20 uur per week werken vaker over te werken. Wellicht maken kleine deeltijdbanen het makkelijker voor assistenten om een paar uur extra te werken. Er zijn geen verschillen in de mate van overwerk gevonden tussen assistenten die werken in zelfstandige 
apotheken of apotheken die deel uitmaken van een keten of maatschap. Ook zijn er op dit punt geen verschillen tussen kleine of grote apotheken, of regionale verschillen. Het werkgeversonderzoek laat ook zien dat overwerk niet als middel wordt ingezet om de knelpunten in de personeelsvoorziening op te lossen.

\section{Bereidheid tot overwerk}

Aan apothekersassistenten in de openbare apotheek is gevraagd of zij, wanneer hun werkgever daarom zou vragen, bereid zijn meer uren te gaan werken. Tabel 5.1 laat zien dat meer dan éénderde van de assistenten hiertoe wel bereid is. Met name schoolverlaters zijn meer dan gemiddeld bereid om meer uren te gaan werken. Ook assistenten met kinderen in de leeftijd van 5 tot 15 jaar zijn meer tot overwerken bereid, net als assistenten die minder dan 20 uur per week of juist fulltime werken. Andere verschillen tussen apothekersassistenten en tussen apotheken blijken niet significant te zijn. Opvallend is verder dat assistenten die al overwerken een grotere bereidheid tonen om meer uren te werken. Dit zou erop kunnen duiden dat het overwerken hen goed bevalt.

Tabel 5.1

Bereidheid om meer uren te gaan werken van apothekersassistenten werkzaam in de openbare apotheek, 2001

$\%$

Soort apothekersassistent

Schoolverlaters $\quad 56$

$\begin{array}{ll}\text { Herintreders } & 34\end{array}$

Overwerk

$\mathrm{Ja}$

Nee

Leeftijd jongste kind

0-2 jaar

3-4 jaar

5-9 jaar

10-14 jaar

15 jaar en ouder

Geen thuiswonende kinderen

34

35

Werkuren per week

Minder dan 20 per week

20 tot 32 uur per week

32 tot 36 uur per week

36 uur per week of meer

Totaal

Bron: ROA

Om hierin enig inzicht te krijgen is aan de assistenten gevraagd aan te geven hoeveel uur per week zij het liefst zouden willen werken. Tabel 5.2 laat zien dat $6 \%$ van de apothekersassistenten meer uren zou willen werken dan zij nu doen. Gemiddeld gaat het om zo'n 5 uur extra werk per week. Assistenten die nu al overwerken zijn inderdaad sterk oververtegenwoordigd in deze groep. Van de apothekersassistenten die overwerk verrichten wil maar liefst $21 \%$ meer uren werken dan zij momenteel 
doen. Bovendien is $60 \%$ van deze assistenten tevreden met het aantal uren dat zij per week werken. Dit duidt erop dat een groot deel van het overwerk dat in de openbare apotheek verricht wordt, met instemming van de apothekersassistenten plaatsvindt. Slechts een minderheid van de assistenten die overwerken wil het liefst minder uren per week werken (20\%).

Tabel 5.2

Gewenste werkuren van apothekersassistenten werkzaam in de openbare apotheek, naar overwerk, 2001

\begin{tabular}{lcrr}
\hline & Wel overwerk & Geen overwerk & Totaal \\
\hline Wil het liefst minder uren per week werken & 19 & 31 & 29 \\
Wil hetzelfde aantal uren per week werken & 60 & 66 & 65 \\
Wil het liefst meer uren per week werken & 21 & 3 & 6 \\
\hline
\end{tabular}

\section{Bron: ROA}

Overigens is de meerderheid van de apothekersassistenten zeer tevreden met het huidige aantal werkuren per week. $65 \%$ Geeft aan dat het aantal uren dat zij nu per week werken ook het aantal gewenste uren is. Bijna $30 \%$ van alle apothekersassistenten zou echter het liefst minder uren willen werken. Gemiddeld gaat het dan om zo'n 6 uur per week minder. Het blijken met name de oudere apothekersassistenten te zijn die minder uren willen gaan werken. Wanneer zij meer dan 20 uur per week werken, zouden ze gebruik kunnen maken van de seniorenregeling om hun wens tot uitvoer te brengen. ${ }^{35}$ Door deze regeling kunnen zij geleidelijk aan minder uren gaan werken met behoud van salaris. Schoolverlaters, herintreders en assistenten die minder dan 20 uur per week werken zijn ondervertegenwoordigd in de groep van assistenten die minder uren zouden willen werken.

\subsection{Taken en werkzaamheden}

Welke werkzaamheden verrichten apothekersassistenten in de openbare apotheek? In schema 5.1 staan de belangrijkste taken vermeld. ${ }^{36}$ Het grootste deel van de werkweek van assistenten wordt gevuld met basistaken als standaard baliecontacten (31\%), medicijnen dispenseren (24\%) en medicatiebewaking (12\%). De bereiding van medicijnen neemt $13 \%$ van hun tijd in beslag; besteltaken - dat wil zeggen beheer van het bestelmodel, bestellingen plaatsen, controleren en uitpakken - 9\%. De farmaceutische patiëntenzorg vormt slechts een klein deel van het takenpakket van apothekersassistenten (6\%). Waarschijnlijk is deze zorg de afgelopen jaren wel steeds belangrijker geworden, maar cijfermatige gegevens hierover ontbreken. De farmaceutische patiëntenzorg houdt meer intensievere baliecontacten in, het geven van diepgaande farmaceutische toelichting bij aflevering of bezorging van medicijnen en het verzorgen van speciale spreekuren rond thema's als astma, diabetes, inconti-

35. PMA (2002). Minder werken vanaf uw vijftigste met behoud van inkomen. Alles over de seniorenregeling van het Pensioenfonds Medewerkers Apotheken (PMA). Den Haag, www.pma-pensioen.nl

36. Zie: G.H.M. Evers, M. van Moorsel en H. van der Werff jr. (2001). Functiedifferentiatie binnen de apothekersbranche. Ideaaltypische profielen in kwalitatieve en kwantitatieve zin. IVA, Tilburg.

40 
nentie, terminale zorg en medicijnbewaking. Met administratieve handelingen als het afhandelen en opbergen van recepten en nota's voor patiënten zijn apothekersassistenten in de openbare apotheek gemiddeld $4 \%$ van hun tijd kwijt.

Schema 5.1

Werkzaamheden van apothekersassistenten werkzaam in de openbare apotheek, 2001

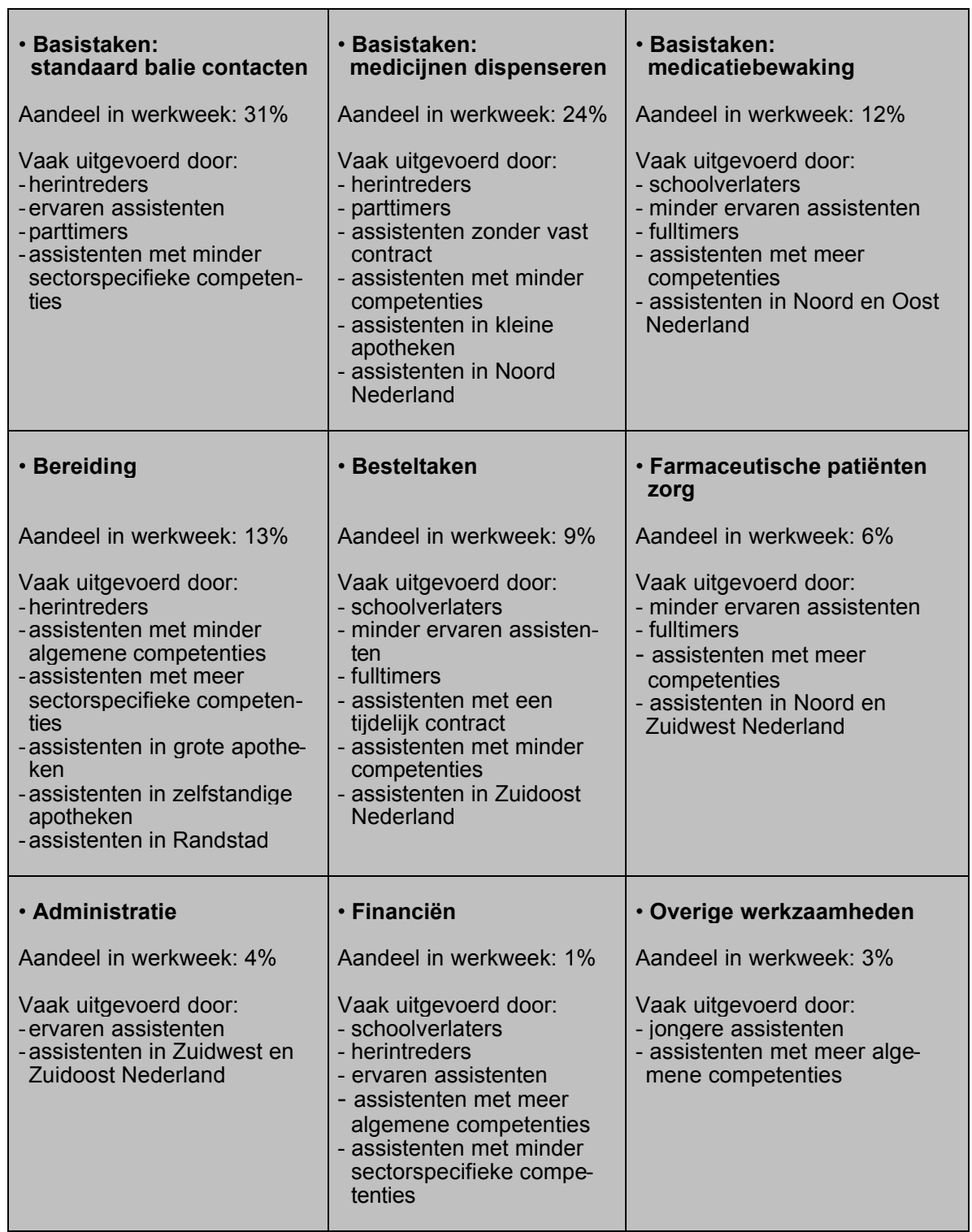

Bron: ROA

Financiële werkzaamheden, dat wil zeggen de loonadministratie en het declaratieverkeer naar de verzekeraars, neemt slecht $1 \%$ van de werkweek in beslag. Aan overige taken zoals werkoverleg, etalagebeheer, schoonmaak en bezorgen, beste- 
den apothekersassistenten in de openbare apotheek gemiddeld ongeveer $3 \%$ van hun werktijd.

In schema 5.1 staat ook vermeld welke apothekersassistenten vaker bepaalde werkzaamheden uitvoeren. Het is opvallend dat herintreders vaker bezig zijn met wat eigenlijk de hoofdtaken van een apothekersassistent zijn. Het gaat dan om basistaken als standaard baliecontacten en medicijnen dispenseren en de bereiding van medicijnen. Ook de in deeltijd werkende assistenten worden relatief veel ingezet voor de basistaken. Tabel 5.3 geeft een gedetailleerd overzicht van de werkzaamheden van deze groepen apothekersassistenten.

Tabel 5.3

Aandeel van werkzaamheden in werkweek voor herintreders en in deeltijd of voltijd werkzame apothekersassistenten in de openbare apotheek, 2001

\begin{tabular}{|c|c|c|c|c|c|c|}
\hline \multirow[b]{2}{*}{ Werkzaamheden } & \multicolumn{6}{|c|}{ Deeltijd of voltijds werkenden } \\
\hline & $\begin{array}{c}\text { Herin- } \\
\text { treders } \\
\%\end{array}$ & $\begin{array}{c}>20 \text { uur } \\
\text { per week } \\
\%\end{array}$ & $\begin{array}{c}20-32 \text { uur } \\
\text { per week } \\
\%\end{array}$ & $\begin{array}{c}\text { 32-36 uur } \\
\text { per week } \\
\quad \%\end{array}$ & $\begin{array}{c}36+\text { uur } \\
\text { per week } \\
\%\end{array}$ & $\begin{array}{c}\text { Totaal } \\
\%\end{array}$ \\
\hline $\begin{array}{l}\text { Basistaken: standaard balie } \\
\text { contacten }\end{array}$ & 33 & 34 & 31 & 29 & 28 & 31 \\
\hline $\begin{array}{l}\text { Basistaken: medicijnen } \\
\text { dispenseren }\end{array}$ & 26 & 25 & 24 & 23 & 23 & 24 \\
\hline $\begin{array}{l}\text { Basistaken: medicatiebewa- } \\
\text { king }\end{array}$ & 10 & 12 & 11 & 13 & 13 & 12 \\
\hline $\begin{array}{l}\text { king } \\
\text { Bereiding } \\
\text { Besteltaken }\end{array}$ & $\begin{array}{r}14 \\
8\end{array}$ & $\begin{array}{r}13 \\
8\end{array}$ & $\begin{array}{r}12 \\
8\end{array}$ & $\begin{array}{r}12 \\
9\end{array}$ & $\begin{array}{l}13 \\
11\end{array}$ & $\begin{array}{r}13 \\
9\end{array}$ \\
\hline $\begin{array}{l}\text { Farmaceutische patiënten- } \\
\text { zorg } \\
\text { Administratie } \\
\text { Financiën } \\
\text { Overige taken }\end{array}$ & $\begin{array}{l}4 \\
3 \\
1 \\
3\end{array}$ & $\begin{array}{l}4 \\
4 \\
1 \\
3\end{array}$ & $\begin{array}{l}5 \\
4 \\
2 \\
3\end{array}$ & $\begin{array}{l}6 \\
4 \\
1 \\
4\end{array}$ & $\begin{array}{l}7 \\
4 \\
1 \\
3\end{array}$ & $\begin{array}{l}6 \\
4 \\
1 \\
3\end{array}$ \\
\hline
\end{tabular}

Bron: ROA

Verder blijken er grote verschillen in werkzaamheden te zijn tussen de meer competente en minder competente apothekersassistenten. Schema 5.1 laat zien dat assistenten met een hoge score op de sectorspecifieke competenties vaak ingezet worden bij de medicatiebewaking, de bereiding van medicijnen en de farmaceutische patiëntenzorg. Assistenten met minder competenties verrichten vaker basistaken als standaard balie contacten en medicijnen dispenseren, besteltaken en financiën. Wanneer men goed scoort op de algemene competenties, dan voert men meer dan gemiddeld werkzaamheden uit in het kader van de medicatiebewaking, de farmaceutische patiëntenzorg, de financiën, of overige werkzaamheden. Assistenten die een lager algemeen competentieniveau hebben, verrichten weer vaker taken als medicijnen dispenseren, bereiding van medicijnen en besteltaken. Dit duidt erop dat sommige werkzaamheden een hoger algemeen of sectorspecifiek competentieniveau vereisen dan andere werkzaamheden en dat er in de openbare apotheek gezocht wordt naar het inzetten van de juiste assistenten voor deze werkzaamheden.

Overigens vinden apothekersassistenten in de openbare apotheek de basistaken de kern van het beroep - het plezierigst. Het feit dat met name herintreders en partti- 
mers deze taken uitvoeren, betekent dat zij niet met de minst leuke klussen opgescheept worden. Figuur 5.2 laat zien dat maar liefst $88 \%$ van de assistenten deze taken met (veel) plezier vervult, voor de herintreders is dit zelfs $92 \%$. Ook het verzorgen van de farmaceutische patiëntenzorg vinden veel assistenten een plezierige werkzaamheid $(81 \%)$, gevolgd door de bereiding van medicijnen $(74 \%)$. Het doen van de financiën en de administratie wordt duidelijk minder vaak als plezierig ervaren (respectievelijk $41 \%$ en $50 \%$ ).

\section{Figuur 5.2}

Plezier in werkzaamheden van apothekersassistenten werkzaam in de openbare apotheek, 2001

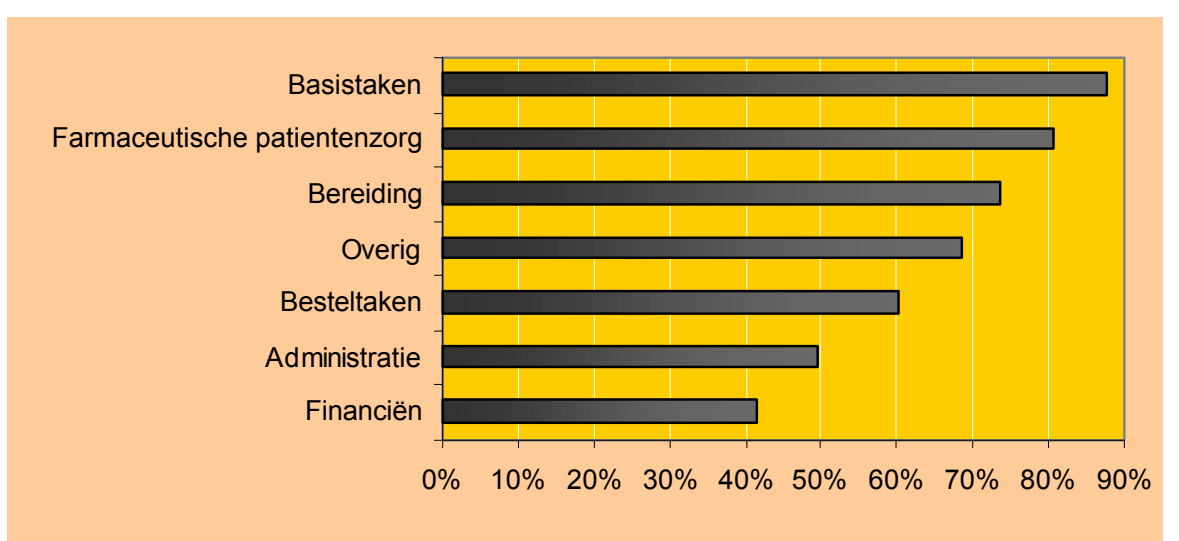

Bron: ROA

\section{Brede inzetbaarheid}

Verrichten apothekersassistenten die werkzaam zijn in de openbare apotheek wel eens taken die strikt genomen niet tot hun functie behoren? Het antwoord op deze vraag kan van belang zijn voor de employability van assistenten. Immers, wanneer apothekersassistenten breed inzetbaar zijn, dan vergroot dit hun vermogen om werk te krijgen en te houden. Tabel 5.4 laat zien dat ongeveer $30 \%$ van de assistenten wel eens taken verricht die niet tot hun functie behoren. $6 \%$ Neemt farmaceutische taken van de apotheker over; $13 \%$ voert wel eens management taken uit zoals het doen van de administratie en personeelszaken. Eén op de zes apothekersassistenten verricht wel eens taken uit andere functies. ${ }^{37}$

Het blijkt dat schoolverlaters en herintreders veel minder breed worden ingezet dan andere apothekersassistenten, net als de in deeltijd werkende apothekersassistenten. Taken die niet tot de functie van apothekersassistent behoren worden beduidend vaker uitgevoerd door assistenten die hoog scoren op zowel de meer algemene als de meer sectorspecifieke competenties. $\mathrm{Er}$ is een zeker competentieniveau nodig om farmaceutische taken van de apotheker, managementtaken en taken uit andere functies te verrichten. Managementtaken worden vaker uitgevoerd door assistenten die werkzaam zijn in kleine apotheken. Uit het onderzoek blijkt ook dat assistenten in 
de Randstad vaker taken uit andere functies verrichten. Dit wijst erop dat apothekers door het breed inzetten van apothekersassistenten proberen de nadelige gevolgen van de personeelstekorten die in deze regio spelen te verminderen.

Tabel 5.4

Werkzaamheden die niet tot de functie behoren verricht door apothekersassistenten in de openbare apotheek, $2001^{\mathrm{a}}$

\begin{tabular}{lccc}
\hline & $\begin{array}{c}\text { Schoolverlaters } \\
\%\end{array}$ & $\begin{array}{c}\text { Herintreders } \\
\%\end{array}$ & $\begin{array}{c}\text { Totaal } \\
\%\end{array}$ \\
\hline Farmaceutische taken van apotheker & 2 & 2 & 6 \\
Management taken & 8 & 5 & 13 \\
Taken uit andere functies & 17 & 11 & 17 \\
Geen taken die niet tot de functie behoren & 76 & 84 & 70
\end{tabular}

${ }^{a}$ Omdat apothekersassistenten meerdere werkzaamheden kunnen verrichten, tellen de percentages niet op tot $100 \%$. Bron: ROA

Naast het daadwerkelijk verrichten van werkzaamheden die strikt genomen niet tot hun functie behoren, is ook de bereidheid van apothekersassistenten om dit te doen van belang voor hun employability. Figuur 5.3 laat zien dat $62 \%$ van de apothekersassistenten bereid is om farmaceutische taken van de apotheker over te nemen, wanneer deze daarom vraagt. $68 \%$ wil wel managementtaken uitvoeren en maar liefst $80 \%$ is bereid om taken uit andere functies te verrichten. Het blijken met name assistenten die jong zijn, weinig werkervaring hebben, fulltime werken, en met een hoge score op de algemene en sectorspecifieke competenties te zijn die bereid zijn om werkzaamheden te verrichten die niet tot hun functie behoren. Juist voor deze assistenten kan het een middel zijn om hun loopbaanperspectieven te vergroten.

Figuur 5.3

Bereidheid van apothekersassistenten werkzaam in de openbare apotheek om werkzaamheden te verrichten die niet tot de functie behoren, 2001

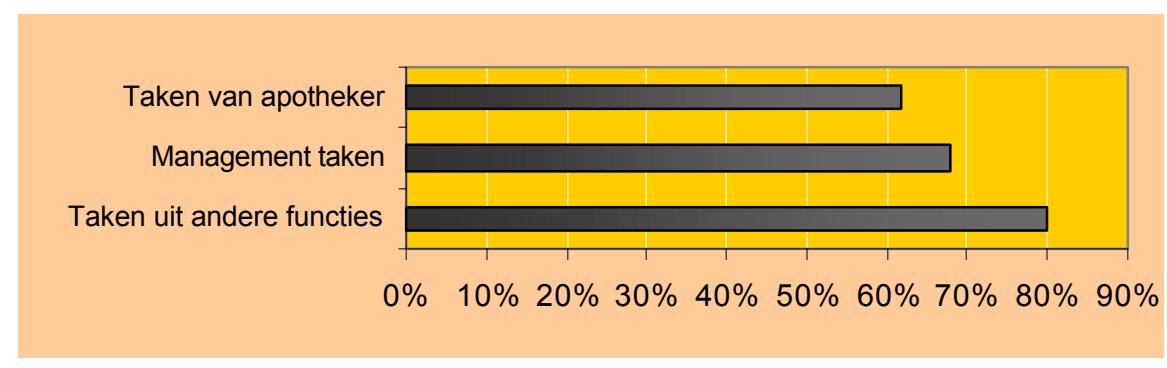

Bron: ROA

\subsection{Loopbaan- en arbeidsmarktperspectieven}

Hoe schatten de apothekersassistenten die in de openbare apotheek werken hun loopbaan- en arbeidsmarktperspectieven in? Om een eerste antwoord op deze vraag te krijgen is aan de assistenten gevraagd aan te geven of zij denken over 5 jaar nog als apothekersassistent in de openbare apotheek te werken. Figuur 5.4 geeft aan dat maar liefst één op de vijf assistenten denkt dan niet meer als apothekersassistent te 
werken. Een groot deel van deze assistenten (59\%) denkt dan ander werk te verrichten, een ander deel (41\%) verwacht dan gestopt te zijn met werken. Deze laatste groep bestaat voornamelijk uit werknemers ouder dan 50 jaar. Ruim tweederde van de apothekersassistenten denkt over 5 jaar nog als assistent in de huidige openbare apotheek te werken. $9 \%$ verwacht nog wel als apothekersassistent te werken, maar dan in een andere apotheek; $3 \%$ zelfs buiten de openbare apotheek.

\section{Figuur 5.4}

Verwachte arbeidssituatie over 5 jaar van apothekersassistenten werkzaam in de openbare apotheek, 2001
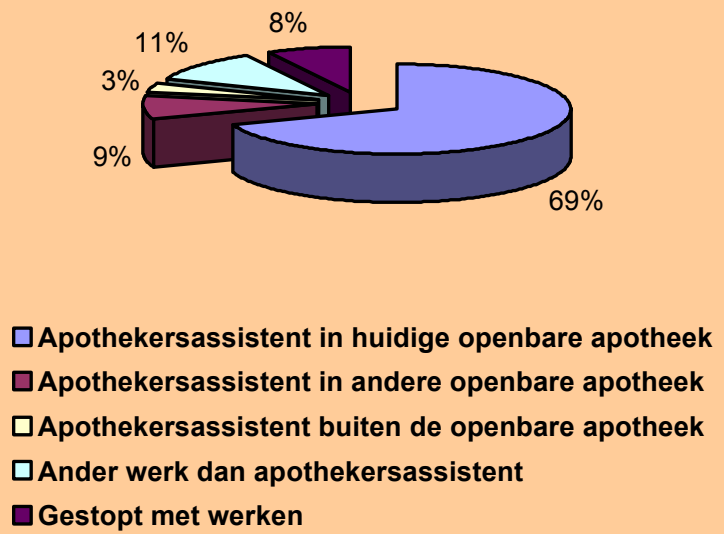

Bron: ROA

Assistenten die aangeven over 5 jaar nog als apothekersassistent in de huidige apotheek te werken zijn minder vaak werkzaam in kleine apotheken. Blijkbaar vinden assistenten de wat grotere apotheken aantrekkelijker om in te werken. Daarnaast werken de 'honkvaste' assistenten beduidend vaker in apotheken in de regio's Oost en Zuidoost Nederland. Uit het werkgeversonderzoek bleek al dat assistenten uit deze regio's minder snel uitstromen en dat hun arbeidsmobiliteit laag is. Ook de werkervaring van apothekersassistenten lijkt hun toekomstverwachtingen te beï nvloeden. Zo daalt het percentage assistenten dat denkt over 5 jaar als apothekersassistent in een andere apotheek aan de slag te zijn, met het aantal jaren werkervaring: van $13 \%$ voor assistenten met weinig werkervaring naar $2 \%$ voor assistenten met veel werkervaring. Hetzelfde geldt voor het percentage apothekersassistenten dat verwacht ander werk te gaan verrichten. Wanneer men dus eenmaal een aantal jaren als apothekersassistent aan het werk is, dan is de intentie om van werkgever of functie te veranderen klein. Enerzijds heeft men dan waarschijnlijk de baan gevonden die men het meest aantrekkelijk vindt. Anderzijds hebben werknemers met veel werkervaring vaak te kampen met zogenaamde ervaringsconcentratie. ${ }^{38}$ Wanneer werknemers lange tijd dezelfde functie binnen dezelfde organisatie

38. J.G.L. Thijssen (1996), Leren, leeftijd en loopbaanperspectief, Kluwer Bedrijfswetenschappen, Deventer. 
vervullen, dan is hun menselijk kapitaal wellicht te specifiek geworden om nog elders ingezet te kunnen worden.

Schema 5.2 geeft een verhelderend inzicht in de belangrijkste redenen die apothekersassistenten geven voor hun verwachting over 5 jaar niet meer als assistent in de huidige openbare apotheek te werken. Assistenten die denken als apothekersassistent in een andere openbare apotheek aan de slag te gaan, noemen met name de werksfeer $(35 \%)$ en de te hoge werkdruk $(34 \%)$ als reden om elders te gaan werken. Ook een te lange reistijd en een te verwachte verhuizing spelen een rol bij het (toekomstig) wisselen van werkgever. Dit bevestigt nogmaals het beeld dat apothekersassistenten het liefst dichtbij hun werk willen wonen. Daarnaast denkt één op de vijf assistenten die van apotheek denken te wisselen in de andere openbare apotheek meer te kunnen verdienen.

Het hogere salaris dat men elders verwacht te kunnen verdienen is tevens de belangrijkste reden om over 5 jaar als apothekersassistent buiten de openbare apotheek te gaan werken (58\%). Ook denkt een groot deel van deze assistenten dat de loopbaanperspectieven buiten de openbare apotheek beter zijn (56\%). De te hoge werkdruk en het niet bevredigend zijn van het soort werk dat men momenteel doet wordt door éénderde van de apothekersassistenten die buiten de openbare apotheek denken te gaan werken genoemd.

Schema 5.2

De vijf belangrijkste redenen waarom apothekersassistenten in de openbare apotheek over 5 jaar niet meer als apothekersassistent in de huidige apotheek werken, $2001^{\mathrm{a}}$.

\begin{tabular}{|c|c|c|c|}
\hline \multicolumn{2}{|c|}{$\begin{array}{l}\text { Werk als apothekersassistent in andere } \\
\text { openbare apotheek }(9 \%)\end{array}$} & \multicolumn{2}{|l|}{$\begin{array}{l}\text { Werk als apothekersassistent buiten de } \\
\text { openbare apotheek }(3 \%)\end{array}$} \\
\hline $\begin{array}{l}\text { 1. Werksfeer } \\
\text { 2. Te hoge werkdruk } \\
\text { 3. Te lange reistijd } \\
\text { 4. Verhuizing } \\
\text { 5. Hoger salaris elders }\end{array}$ & $\begin{array}{l}35 \% \\
34 \% \\
29 \% \\
24 \% \\
20 \%\end{array}$ & $\begin{array}{l}\text { 1. Hoger salaris elders } \\
\text { 2. Betere loopbaanperspectieven elders } \\
\text { 3. Te hoge werkdruk } \\
\text { 4. Soort werk is niet bevredigend } \\
\text { 5. Werksfeer }\end{array}$ & $\begin{array}{l}58 \% \\
56 \% \\
34 \% \\
34 \% \\
29 \%\end{array}$ \\
\hline \multicolumn{2}{|c|}{$\begin{array}{l}\text { Ander werk dan apothekersassistent } \\
(11 \%)\end{array}$} & \multicolumn{2}{|l|}{ Gestopt met werken (8\%) } \\
\hline $\begin{array}{l}\text { 1. Hoger salaris elders } \\
\text { 2. Soort werk is niet bevredigend } \\
\text { 3. Te hoge werkdruk } \\
\text { 4. Werksfeer } \\
\text { 5. Opleiding/studie volgen }\end{array}$ & $\begin{array}{l}48 \% \\
44 \% \\
40 \% \\
21 \% \\
21 \%\end{array}$ & $\begin{array}{l}\text { 1. Pensionering / leeftijd } \\
\text { 2. Zorgtaken } \\
\text { 3. Te hoge werkdruk } \\
\text { 4. Werksfeer } \\
\text { 5. Soort werk is niet bevredigend }\end{array}$ & $\begin{array}{r}60 \% \\
28 \% \\
14 \% \\
8 \% \\
6 \%\end{array}$ \\
\hline
\end{tabular}

Ook assistenten die verwachten over 5 jaar niet meer als apothekersassistent te werken, maar een andere baan te hebben, geven als belangrijkste reden op dat zij denken elders een hoger salaris kunnen verdienen (48\%). Dit duidt erop dat er iets met de salariëring dient te gebeuren, wil men deze apothekersassistenten voor de openbare apotheek behouden. Dit proces is al gedeeltelijk in gang gezet door het in 2003 in te voeren systeem van functiewaardering en de bijbehorende salarisverho- 
ging, waardoor veel apothekersassistenten er de komende tijd op vooruit zullen gaan. Verder noemen assistenten die in de toekomst ander werk willen verrichten als reden dat het soort werk niet bevredigend is (44\%), de werkdruk te hoog $(40 \%)$ en de werksfeer niet goed $(21 \%)$ is. Daarnaast denkt één op de vijf assistenten een opleiding of studie te gaan volgen.

We zagen al eerder dat de assistenten die over 5 jaar denken te stoppen met werken vooral oudere werknemers zijn. Dit blijkt ook uit de redenen die zij opgeven om te stoppen. Maar liefst $60 \%$ stopt binnen 5 jaar met het werk vanwege pensionering of leeftijd. 28\% Van de assistenten noemt als reden de zorg voor kinderen, huishoudelijk werk of andere zorgtaken. Ten slotte stopt een deel van de apothekersassistenten omdat ze de werkdruk te hoog vinden $(14 \%)$, de werksfeer niet goed is $(8 \%)$ of omdat ze het soort werk niet bevredigend vinden (6\%).

\section{Zoekgedrag van apothekersassistenten}

Naast de toekomstverwachtingen van apothekersassistenten in de openbare apotheek, kunnen we ook nagaan of zij op het moment van de enquête actief op zoek zijn naar een andere baan. Tabel 5.5 laat zien dat één op de tien assistenten daadwerkelijk op zoek is naar een andere baan. $3 \%$ Van de assistenten wil graag apothekersassistent blijven, maar dan wel bij een andere openbare apotheek. Ongeveer $1 \%$ zoekt een baan als apothekersassistent buiten de openbare apotheek. De meeste assistenten die bij de apotheek waar ze momenteel weg willen, zijn echter op zoek naar een baan in een andere functie. Zo zoekt $4 \%$ van alle apothekersassistenten naar een andere functie binnen de apothekersbranche en wil $5 \%$ een andere functie buiten de sector. Herintreders zijn overigens wat minder vaak op zoek zijn naar een andere baan (8\%).

Tabel 5.5

Zoekgedrag van apothekersassistenten werkzaam in de openbare apotheek, $2001^{\mathrm{a}}$

\begin{tabular}{lc}
\hline & $\%$ \\
\hline Niet op zoek naar een andere baan & 89 \\
& \\
Wel op zoek naar een andere baan... & 3 \\
...als apothekersassistent in andere openbare apotheek & 1 \\
...als apothekersassistent buiten de openbare apotheek & 4 \\
...in een andere functie, maar wel binnen de sector & 5 \\
\hline a. een andere functie, maar dan buiten de sector & \\
\hline Omdat apothekersassistenten op zoek kunnen zijn naar meerdere soorten banen, tellen de
\end{tabular}
Bron: ROA

Arbeidsmarktperspectieven binnen en buiten de sector

Hoe schatten apothekersassistenten hun arbeidsmarktperspectieven binnen en buiten de branche in? Figuur 5.5 geeft aan dat de meeste apothekersassistenten hun arbeidsmarktperspectieven binnen de sector rooskleurig inzien. 62\% Van de assistenten denkt dat het (zeer) gemakkelijk is om een minstens even aantrekkelijke baan 
elders binnen de branche te vinden. Het vinden van een baan buiten de sector wordt als moeilijker beschouwd. Slechts één op de vijf apothekersassistenten denkt dat het (zeer) gemakkelijk is om een minstens even aantrekkelijke baan buiten de sector te vinden. Ook is het percentage assistenten dat geen idee heeft van de arbeidsmarktperspectieven buiten de branche groter dan bij de vraag naar een baan binnen de branche (14\% versus $8 \%)$. Overigens blijkt uit het werkgeversonderzoek dat de apothekers de arbeidsmarktperspectieven van de apothekersassistenten buiten de branche hoger inschatten dan de assistenten zelf. Van de apothekers meent $31 \%$ dat het voor assistenten (zeer) gemakkelijk is om een even aantrekkelijke baan buiten de branche te vinden. Apothekersassistenten hebben een minder rooskleurig beeld van hun kansen op een aantrekkelijke baan buiten de branche of ze zijn meer gehecht aan hun beroep dan apothekers denken.

\section{Figuur 5.5}

Moeilijkheid om binnen of buiten de apotheekbranche een minstens even aantrekkelijke andere baan te vinden, 2001

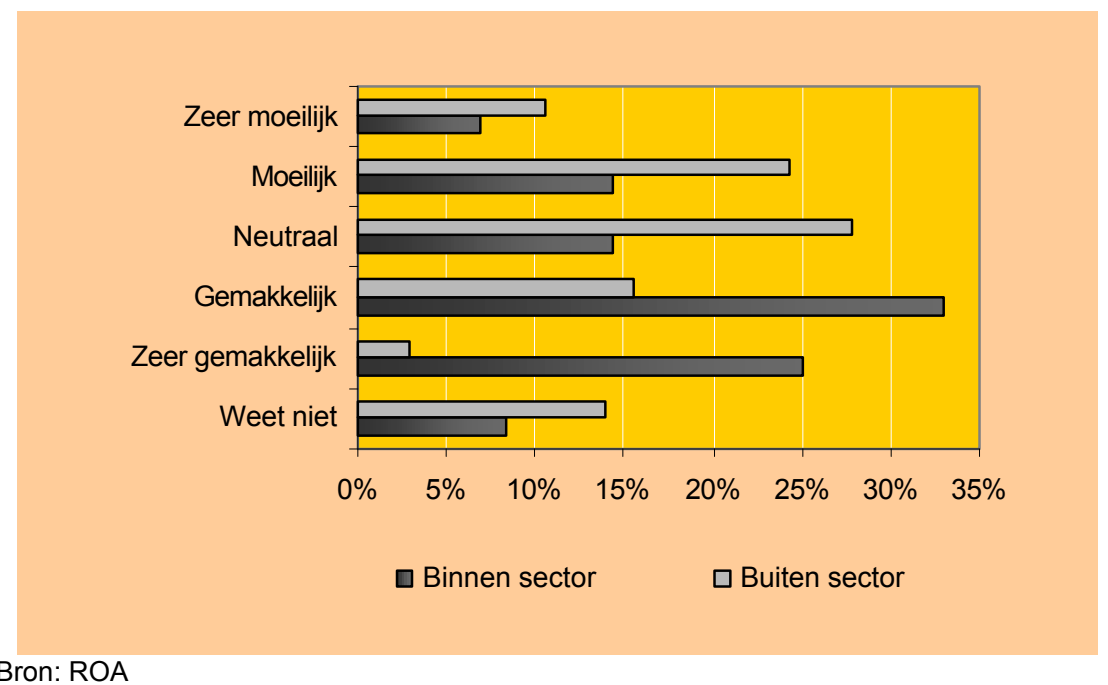

Over het algemeen denken apothekersassistenten met veel werkervaring vaker dat het vinden van een minstens even aantrekkelijke baan, zowel binnen als buiten de branche, moeilijk is. Dit heeft waarschijnlijk te maken met wat we eerder beschreven als de ervaringsconcentratie van werknemers. Assistenten die al lang hun functie uitoefenen, beschikken doorgaans over sectorspecifieke en bedrijfsspecifieke kennis en vaardigheden. Dit maakt het moeilijker om elders in een meer aantrekkelijke baan aan de slag te gaan. Het is in dit opzicht dan ook niet verwonderlijk dat apothekersassistenten die in een andere functie werkervaring opgedaan hebben, het vinden van een minstens even aantrekkelijke baan buiten de branche vaker als gemakkelijk inschatten. Verder blijken er enkele regionale verschillen te bestaan. Zo schatten assistenten in de Randstad hun arbeidsmarktperspectieven gunstiger in dan elders in Nederland. Dit geldt zowel voor banen binnen als buiten de branche. Deze betere arbeidsmarktperspectieven hangen duidelijk samen met de grote personeelstekorten in de Randstad. In de regio Oost Nederland daarentegen is het - volgens de assis- 
tenten - minder gemakkelijk om aan een even aantrekkelijke baan binnen of buiten de branche te vinden. Assistenten in de regio Noord Nederland ten slotte beoordelen de arbeidsmarktperspectieven binnen de branche als gunstiger, maar buiten de branche als ongunstiger. Dit beeld wordt bevestigd door de apothekers, zo blijkt uit het werkgeversonderzoek. In het volgende hoofdstuk zullen we uitgebreider aandacht besteden aan de invloed van allerlei factoren op de loopbaan- en arbeidsmarktperspectieven van apothekersassistenten. 



\section{Effecten van scholing, flexibiliteit en brede inzetbaarheid}

\subsection{Inleiding}

In de vorige twee hoofdstukken is de employability van apothekersassistenten in de openbare apotheek in kaart gebracht. Eerst is beschreven hoe assistenten hun competenties ontwikkelen. De meeste aandacht ging daarbij uit naar de scholing en cursussen die assistenten volgen. Daarna kwam de flexibiliteit en inzetbaarheid van apothekersassistenten aan de orde: het verrichten van overwerk en van taken die niet tot de functie van apothekersassistent behoren. In dit hoofdstuk worden de mogelijke effecten van deze scholing, flexibiliteit en brede inzetbaarheid onderzocht. Daarbij baseren we ons op de verbanden die we vinden tussen de antwoorden op de verschillende vragen die we aan de apothekersassistenten en apothekers gesteld hebben. Een dergelijke statistische analyse heeft als groot voordeel dat er onverwachte relaties gelegd kunnen worden die de discussie binnen de branche over een aantal belangrijke zaken kan bevorderen. Aan de andere kant zullen dergelijke uitkomsten nieuwe vragen opwerpen of de wens oproepen door het stellen van meer of betere vragen de gevonden effecten beter te onderzoeken. Naarmate de arbeidsmarktmonitor voor de openbare apotheek over een langere periode de ontwikkelingen op de arbeidsmarkt voor apothekersassistenten volgt, zal het inzicht in deze punten steeds scherper worden.

In de eerste plaats komen in dit hoofdstuk de effecten van scholing, flexibiliteit en brede inzetbaarheid op het salaris van apothekersassistenten aan bod. Assistenten die meer cursussen volgen en zich flexibel opstellen wat hun uren en taken betreft, zijn meer employabel en dus aantrekkelijker ervoor werkgevers. Komt deze aantrekkelijkheid ook tot uiting in een hoger salaris voor deze apothekersassistenten? Paragraaf 6.2 probeert een antwoord te geven op deze vraag.

Daarna worden in paragraaf 6.3 de effecten op de werkdruk en het ziekteverzuim in de openbare apotheek onderzocht. Hoofdstuk 3 liet zien dat apothekersassistenten met een vrij hoge werkdruk te maken hebben. Ook bleek het werkgerelateerde ziekteverzuim in de openbare apotheek redelijk hoog te zijn. Is het mogelijk om deze werkdruk te verminderen en het ziekteverzuim terug te dringen door de employability van assistenten te vergroten? Of leidt meer scholing, flexibiliteit en brede inzetbaarheid juist tot een hogere werkdruk en meer ziekteverzuim?

In paragraaf 6.4 wordt aandacht besteed aan de effecten van scholing, flexibiliteit en brede inzetbaarheid op de tevredenheid van apothekersassistenten met hun werk. Zijn employabele assistenten door de cursussen die ze volgen, het overwerken en het verrichten van taken die niet tot hun functie behoren meer tevreden dan andere assistenten in de openbare apotheek?

Ten slotte worden de effecten op de loopbaan- en arbeidsmarktperspectieven van apothekersassistenten nagegaan. Zoals gezegd zijn employabele assistenten aan- 
trekkelijke werknemers, niet alleen in de ogen van hun huidige baas, maar ook voor andere werkgevers. Paragraaf 6.5 beschrijft in hoeverre scholing, flexibiliteit en brede inzetbaarheid de arbeidsmarktperspectieven van assistenten binnen en buiten de apothekersbranche vergroten. Daarnaast worden de effecten van employability op het zoekgedrag van assistenten in kaart gebracht. Zijn apothekersassistenten die cursussen volgen, overwerken en taken verrichten die niet tot hun functie behoren eerder op zoek naar een andere baan?

Bij het bepalen van de effecten van scholing, flexibiliteit en brede inzetbaarheid op de genoemde terreinen in de openbare apotheek wordt vanzelfsprekend ook rekening gehouden met een aantal andere belangrijke kenmerken van apothekersassistenten, zoals het wel of niet schoolverlater of herintreder zijn, het aantal jaren werkervaring, het aantal werkuren per week, het hebben van een vast contract en het competentieniveau. Bovendien worden enkele kenmerken van de apotheken waar zij werkzaam zijn in de analyses opgenomen. Het gaat dan om het soort apotheek, de apotheekgrootte, de regio waar de apotheek gevestigd is en of er belangrijke veranderingen in het werk hebben plaatsgevonden. Verder worden ook de effecten van enkele Human Resource Management (HRM) instrumenten in de openbare apotheek bekeken. Het HRM beleid is immers gericht op het optimaliseren van de inzet van werknemers. In de eerste plaats gaat het daarbij om bepaalde aspecten van het arbeidsvoorwaardenbeleid, namelijk of er sprake is van aanvullingen op de kinderopvangregeling $\mathrm{CAO}$, functioneringsgesprekken, prestatiebeloning, flexibele werktijden en het aanbieden van extra kleedgeld, reiskostenregeling, verlofsparen, PC-privé project, fietsenplan en spaarloonregeling aan assistenten. Het arbeidsvoorwaardenbeleid is gericht op het creëren van een prettig en stimulerend werkklimaat in de openbare apotheek en zou zo invloed kunnen uitoefenen op de werkdruk, het ziekteverzuim, de tevredenheid en het zoekgedrag van apothekersassistenten. Daarnaast wordt nagegaan welke invloed het wervings- en selectiebeleid in de openbare apotheek heeft. Het gaat dan met name om het treffen van maatregelen om moeilijk vervulbare vacatures op te vullen. ${ }^{39}$

\subsection{Effecten op salaris}

In deze paragraaf wordt onderzocht of scholing, flexibiliteit en brede inzetbaarheid het salaris van apothekersassistenten beï nvloeden. Volgens de CAO Apotheken wordt het salaris van apothekersassistenten bepaald aan de hand van het aantal dienstjaren (werkervaring) en de door hen met een diploma of certificaat afgeronde scholing. ${ }^{40}$ Apothekers zouden dit salaris echter voor bepaalde groepen apothekersassistenten buiten de CAO om kunnen verhogen. Zo zouden zij competente en flexibel ingestelde apothekersassistenten meer kunnen betalen omdat zij in hun ogen aantrekkelijk en slagvaardig personeel zijn dat breed inzetbaar is. Is het zo dat employabele assistenten beter betaald worden dan andere assistenten?

39. In de analyses met betrekking tot het salaris en de arbeidsmarktperspectieven binnen en buiten de branche worden deze aspecten van het arbeidsvoorwaardenbeleid en het treffen van maatregelen om moeilijk vervulbare vacatures op te vullen niet meegenomen, omdat er geen causaal verband verwacht wordt met deze HRM instrumenten.

40. SBA (2001). Collectieve arbeidsovereenkomst Apotheken 2001. Nieuwegein.

52 
In schema 6.1 staan de belangrijkste effecten op het bruto salaris van apothekersassistenten in de openbare apotheek. Zoals verwacht leidt meer werkervaring tot een hoger salaris. Hierbij telt echter niet alleen de werkervaring als apothekersassistent, maar ook de werkervaring die men elders heeft opgedaan mee. Opvallend in dit verband is dat schoolverlaters en herintreders, ook nadat er rekening gehouden is met hun werkervaring, minder verdienen dan andere apothekersassistenten.

Schema 6.1

Belangrijkste factoren die van invloed zijn op het bruto salaris van apothekersassistenten in de openbare apotheek, 2001

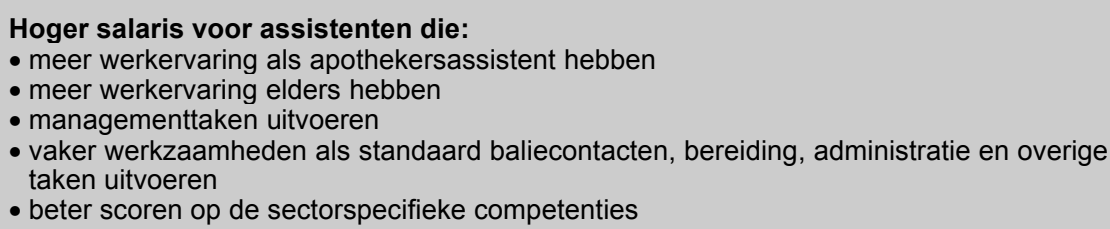

Wat de employability van apothekersassistenten betreft, verdienen assistenten die managementtaken uitvoeren meer dan andere assistenten. Ook het vaker uitvoeren van werkzaamheden als standaard baliecontacten, bereiding van medicijnen, administratie en overige taken zoals etalagebeheer en bezorgen leidt tot een hoger salaris. Dit duidt erop dat apothekersassistenten die breed inzetbaar zijn, meer verdienen. Ook het volgen van cursussen blijkt het salaris van apothekersassistenten niet te beï nvloeden. Hierbij moet echter wel opgemerkt worden dat het hierbij alleen gaat om cursussen die de assistenten het afgelopen jaar gevolgd hebben. Om in aanmerking te komen voor de in de CAO vastgestelde salarisverhoging, dienen assistenten 120 studiepunten te verzamelen. Aangezien een cursus gemiddeld 21 studiepunten oplevert (zie hoofdstuk 4), moeten er heel wat cursussen gevolgd worden om voor deze salarisverhoging in aanmerking te komen. Wel is het zo dat apothekersassistenten met een hogere score voor hun sectorspecifieke competenties meer betaald krijgen. Deze competenties hebben ook een directe relatie met het werk als apothekersassistent (bijvoorbeeld het bereiden van medicijnen). Apothekersassistenten met een hogere score op hun algemene competenties worden daarentegen niet hoger beloond.

Ten slotte blijkt uit deze analyse opnieuw dat apotheekkenmerken geen invloed hebben op het salaris van apothekersassistenten. Net als in hoofdstuk 3 vinden we tussen zelfstandige en niet-zelfstandige apotheken of tussen kleine en grote apotheken geen verschillen in het salaris van apothekersassistenten. Ook zijn er geen regionale verschillen in beloning. Met name deze laatste bevinding is interessant, omdat het erop duidt dat er geen sprake is van een regio-opslag in het salaris. Apothekersassistenten die werkzaam zijn in regio's waar grote knelpunten op de 
arbeidsmarkt zijn, zoals bijvoorbeeld de Randstad, krijgen dus niet significant meer betaald dan assistenten in andere regio's.

\subsection{Effecten op werkdruk en ziekteverzuim}

De employability van apothekersassistenten zou ook de werkdruk en het ziekteverzuim in de openbare apotheek kunnen beï nvloeden. Competente, flexibele en breed inzetbare assistenten zijn immers in staat om beter te reageren en te anticiperen op veranderingen in hun arbeidstaken en werkomgeving. Door efficiënt te werken zou de werkdruk kunnen verminderen en wellicht het ziekteverzuim kunnen worden teruggebracht. Tegelijkertijd moet echter erkend worden dat flexibiliteit waarschijnlijk ook meer stress voor de assistenten met zich mee brengt. Met name overwerk en het verrichten van taken die niet tot de functie van apothekersassistent behoren blijken tot een hogere werkdruk in de apotheek te leiden, zo was een conclusie uit het werkgeversonderzoek. De vraag die in deze paragraaf centraal staat luidt dan ook of scholing, flexibiliteit en een brede inzetbaarheid de werkdruk en het ziekteverzuim van apothekersassistenten kunnen verminderen.

\section{Schema 6.2}

Belangrijkste factoren die van invloed zijn op de ervaren werkdruk van apothekersassistenten in de openbare apotheek, 2001

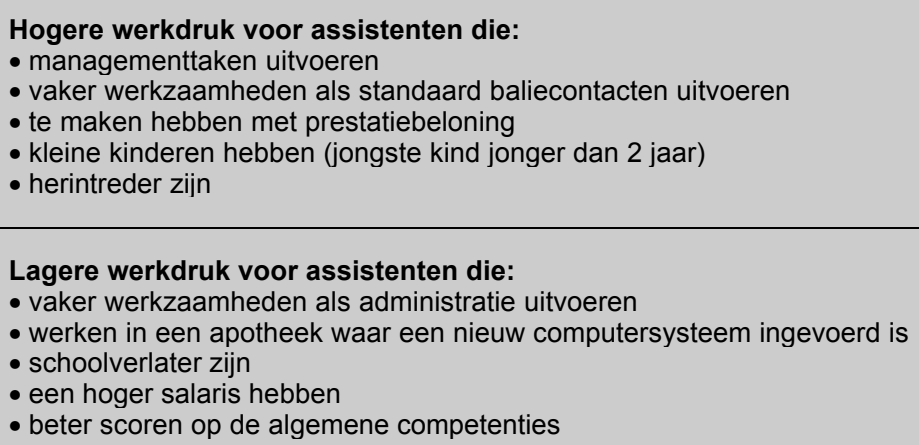

\section{Effecten op de werkdruk}

Schema 6.2 beschrijft de belangrijkste effecten op de ervaren werkdruk van apothekersassistenten. Allereerst valt op dat een brede inzetbaarheid tot een hogere werkdruk leidt. Dat wil zeggen, wanneer er sprake is van het uitvoeren van managementtaken door apothekersassistenten. Het verrichten van andere taken die niet tot hun functie behoren heeft daarentegen geen invloed op de werkdruk, of zorgt zelfs voor een lagere werkdruk zoals bij assistenten die vaker de administratie doen. Het vaker uitvoeren van standaard baliecontacten blijkt overigens ook tot een hogere werkdruk te leiden. Verder is het opmerkelijk dat overwerk niet tot een hogere werkdruk leidt. Wellicht heeft dit te maken met het feit dat de meeste apothekersassistenten die overwerken dit vrijwillig en graag doen (zie hoofdstuk 5). Aangezien veel overwerk in de openbare apotheek bestaat uit het draaien van extra diensten op zaterdag volgens een vast patroon, zal dit weinig belasting voor de assistenten 
opleveren. Daarnaast is het niet uitgesloten dat overwerk ertoe leidt dat de werkdruk in de openbare apotheek tijdens de normale werktijden afneemt.

Apothekersassistenten die zeggen te maken hebben met prestatiebeloning ervaren wel een hogere werkdruk. Misschien voelen zij zich meer opgejaagd dan assistenten die niet met deze vorm van beloning te maken hebben. Verder blijken schoolverlaters een lagere werkdruk te ervaren. Daarentegen hebben apothekersassistenten met kleine kinderen en herintreders juist met een hogere werkdruk te kampen. Wellicht betekent dit dat deze laatste twee groepen assistenten het moeilijk vinden om werk en zorgtaken te combineren. Toch blijkt het aanbieden van aanvullingen op de kinderopvangregeling CAO deze werkdruk niet te kunnen verlagen. Ook de andere HRM instrumenten op het gebied van arbeidsvoorwaarden en werving en selectie beï nvloeden de werkdruk van apothekersassistenten niet. Wel is het zo dat het invoeren van een nieuw computersysteem een positief effect op de door assistenten ervaren werkdruk heeft. Het automatiseren van een aantal standaard handelingen zorgt ervoor dat de werkdruk aanzienlijk vermindert. Ook blijken assistenten die meer verdienen een lagere werkdruk te ervaren. Mogelijk voelen zij zich op deze wijze gecompenseerd voor de werkdruk in de openbare apotheek en vinden zij daarom de werkdruk aanvaardbaar en lager.

Ook blijkt dat apothekersassistenten die beter scoren op de algemene competenties als communicatieve vaardigheden, zelfstandigheid, omgaan met verantwoordelijkheid en omgaan met collega's een lagere werkdruk te ervaren. Deze grotere vaardigheden stellen hen kennelijk in staat hun werk effectiever te verrichten en op plezierige wijze met klanten en collega's om te gaan. Sectorspecifieke competenties daarentegen spelen geen significante rol bij het verlagen van de werkdruk van apothekersassistenten. Een HRM beleid dat zich richt op het verbeteren van de algemene competenties van apothekersassistenten zal overigens niet direct de ervaren werkdruk verminderen. Het blijkt immers dat het volgen van cursussen geen invloed heeft op de werkdruk die apothekersassistenten in de openbare apotheek ervaren. Het werkgeversonderzoek kwam tot een soortgelijke conclusie voor de werkdruk op apotheekniveau en gaf als mogelijk verklaring dat cursussen op de korte termijn voornamelijk tijd en energie kosten. Dit zou het eventuele positieve effect van deze cursussen op de werkdruk, namelijk het vergroten van de competenties van assistenten en daardoor het vergroten van hun efficiëntie, wellicht teniet kunnen doen.

\section{Effecten op het ziekteverzuim}

Uit schema 6.3 blijkt dat met name assistenten die onder slechte omstandigheden hun werk moeten uitvoeren meer ziek zijn. Apothekersassistenten die regelmatig met geestelijk zwaar werk te maken hebben zijn vaker kortdurig ziek, terwijl assistenten die regelmatig onder hoge tijdsdruk werken vaker langer ziek zijn. Ook wanneer assistenten regelmatig met slechte fysieke omstandigheden te maken hebben is het 
ziekteverzuim hoger. In de literatuur wordt overigens vaker melding gemaakt van het feit dat arbeidsomstandigheden het ziekteverzuim beï nvloeden. ${ }^{41}$

\section{Schema 6.3}

Belangrijkste effecten op het ziekteverzuim van apothekersassistenten in de openbare apotheek, 2001

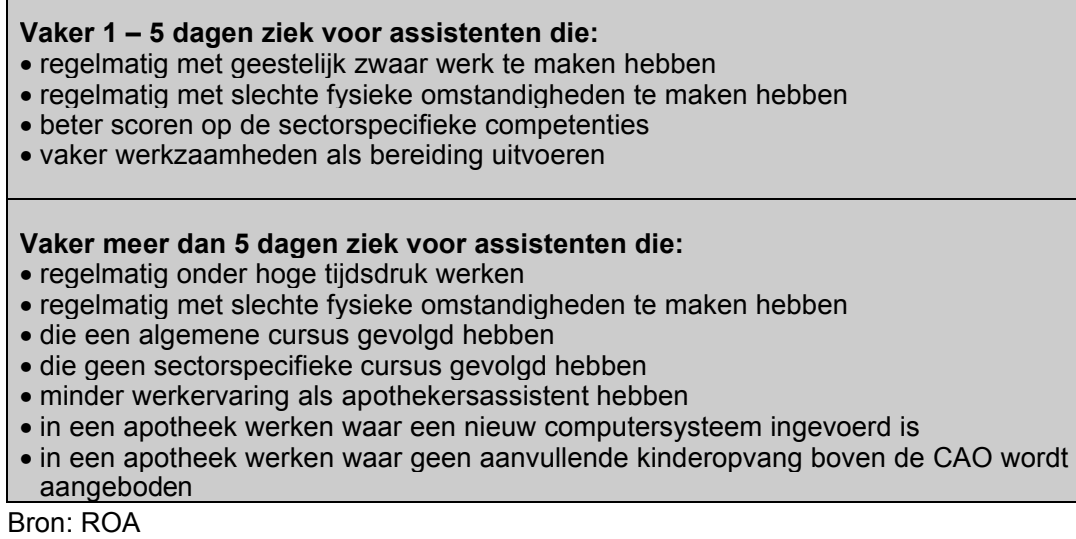

Ook bestaat er een relatie tussen het volgen van scholing en het ziekteverzuim. Deze relatie is echter niet zo eenduidig. Apothekersassistenten die een sectorspecifieke cursus gevolgd hebben zijn minder langdurig ziek dan assistenten die niet zo'n cursus gevolgd hebben. Echter, het volgen van een algemene cursus heeft juist het omgekeerde effect.

Assistenten die beter scoren op de sectorspecifieke competenties hebben een grotere kans om 1 tot 5 dagen per jaar ziek te zijn. Hetzelfde geldt voor assistenten die zich veel bezighouden met de bereiding van medicijnen. Daarnaast blijken assistenten met weinig werkervaring als apothekersassistent langduriger ziek te zijn. We kunnen dus concluderen dat de employability van apothekersassistenten slechts in beperkte mate hun ziekteverzuim beï nvloedt. Dit blijkt ook uit het feit dat flexibiliteit en brede inzetbaarheid geen effect hebben op het ziekteverzuim van assistenten.

Het invoeren van een nieuw computersysteem lijkt het ziekteverzuim te vergroten. Apothekersassistenten die in een apotheek werken waar deze automatisering is ingevoerd, ervaren - zoals we net zagen - een lagere werkdruk, maar melden zich wel vaker ziek. Ten slotte is het opvallend dat het aanbieden van aanvullingen op de kinderopvangregeling CAO het langdurig ziekteverzuim terug kan dringen. Dit betekent dat apothekers kunnen inspelen op ziekteverzuim dat mede veroorzaakt wordt door de problemen die assistenten ondervinden bij het combineren van werk en zorgtaken. Uit het werkgeversonderzoek blijkt dat zij dit daadwerkelijk ook doen: aanvullingen op de kinderopvangregeling CAO worden vooral aangeboden in apotheken waar een hoog ziekteverzuim heerst. Andere HRM instrumenten op het

41. Zie bijvoorbeeld R.M. Leontaridi en M.E. Ward (2002). Work-Related Stress, Quitting Intentions and Absenteeism. IZA Discussion Paper no 493. Bonn. 
gebied van arbeidsvoorwaarden of werving en selectie hebben geen effect op het ziekteverzuim.

\subsection{Effecten op tevredenheid met werk}

Uit hoofdstuk 3 bleek dat maar liefste $87 \%$ van de apothekersassistenten over het algemeen (zeer) tevreden is met hun huidige werk. In hoeverre beï nvloedt de employability van assistenten nu deze tevredenheid? Zijn apothekersassistenten die scholing volgen, of die flexibel en breed inzetbaar zijn, meer tevreden met hun werk? Schema 6.4 geeft een overzicht van de belangrijkste factoren die van invloed zijn op de algemene tevredenheid met het werk. Hieruit blijkt dat het volgen van cursussen niet tot een grotere tevredenheid leidt. Wel zijn apothekersassistenten die beter scoren op de sectorspecifieke competenties meer tevreden met hun werk. Dit is wellicht niet vreemd; deze assistenten doen werk waar ze goed in zijn.

\section{Schema 6.4}

Belangrijkste factoren die van invloed zijn op de tevredenheid met het werk van apothekersassistenten in de openbare apotheek, 2001

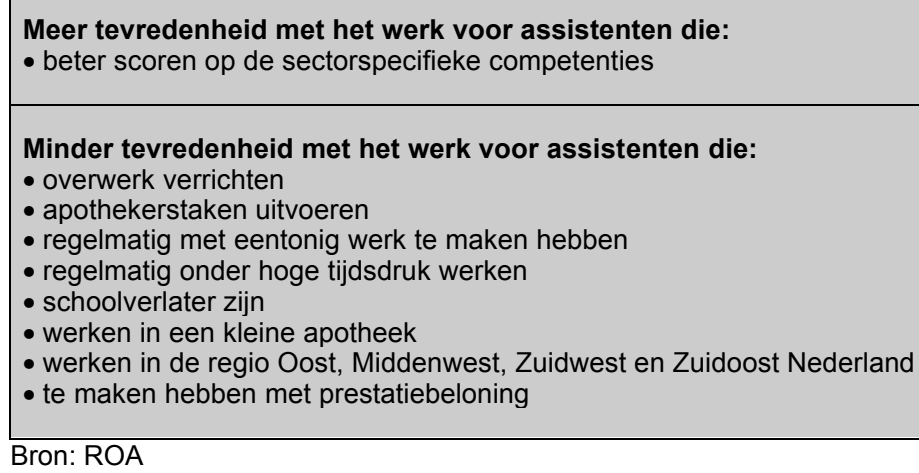

Verder blijkt dat apothekersassistenten die overwerken over het algemeen minder tevreden te zijn. Dit is opmerkelijk, aangezien hoofdstuk 5 laat zien dat de meeste apothekersassistenten vrijwillig en graag overwerken en zelfs bereid zijn om nog meer uren over te werken. Wellicht zijn zij wel tevreden met hun overwerk, maar ontevreden over de te geringe omvang van hun aanstelling of over andere aspecten van hun werk als apothekersassistent. Ook assistenten die breed inzetbaar zijn - in die zin dat zij farmaceutische taken van de apotheker uitvoeren - zijn minder tevreden. Maar over het algemeen moeten we concluderen dat de invloed van de employability op de tevredenheid van assistenten gering is.

Duidelijk is wel dat assistenten die zeggen regelmatig met eentonig werk te maken te hebben, minder tevreden zijn. Ook het regelmatig onder hoge tijdsdruk werken leidt tot minder tevredenheid met het werk. Opvallend is dat de andere arbeidsomstandigheden als het verrichten van lichamelijk of geestelijk zwaar werk en het onder slechte fysieke omstandigheden werken de tevredenheid van apothekersassistenten niet beï nvloeden. Verder blijkt dat schoolverlaters minder tevreden te zijn met hun werk, 
net als assistenten die in een kleine apotheek werken of werkzaam zijn in de regio's Oost, Middenwest, Zuidwest en Zuidoost Nederland.

Het gevoerde HRM beleid op het gebied van arbeidsvoorwaarden en werving en selectie blijkt geen direct effect te hebben op de algemene tevredenheid van apothekersassistenten met hun werk. Wel zijn assistenten die met prestatiebeloning te maken hebben, ontevredener over hun werk. Deze vorm van beloning is duidelijk niet populair onder apothekersassistenten, zoals bleek uit hoofdstuk 3. Ook het werkgeversonderzoek liet zien dat apothekers die aan prestatiebeloning doen minder aantrekkelijke werkgevers zijn. Bovendien bleek uit de vorige paragraaf dat prestatiebeloning tot een hogere werkdruk leidt.

\subsection{Effecten op loopbaan- en arbeidsmarktperspectieven}

Competente, flexibele en breed inzetbare apothekersassistenten zullen gewild zijn op de arbeidsmarkt. Zij vormen de door werkgevers graag geziene slagvaardige werknemers die op meerdere taken en uren ingezet kunnen worden. De vraag is nu of employability zich inderdaad vertaalt naar betere arbeidsmarktperspectieven, zowel binnen als buiten de apothekersbranche. Hierbij moet rekening gehouden worden met het feit dat de arbeidsmarkt voor apothekersassistenten een professionele vakdeelmarkt is. ${ }^{42}$ Dit betekent dat er een nauwe aansluiting tussen opleiding en beroep bestaat. De uitwijkmogelijkheden voor apothekersassistenten lijken dus gering. Dit bleek ook al uit hoofdstuk 5, waar aangegeven werd dat de arbeidsmarktperspectieven buiten de branche door assistenten als minder rooskleurig ingeschat worden dan binnen de branche.

In schema 6.5 staan de belangrijkste factoren die van invloed zijn op de arbeidsmarktperspectieven die apothekersassistenten binnen de branche denken te hebben. Hieruit blijkt dat assistenten, die overwerk verrichten, het vinden van een minstens even aantrekkelijke baan elders binnen de branche als gemakkelijker inschatten dan assistenten die niet overwerken. In dit opzicht percipiëren employabele apothekersassistenten dus inderdaad betere arbeidsmarktperspectieven. De andere aspecten van employability, zoals scholing en een brede inzetbaarheid, blijken echter geen invloed te hebben op de arbeidsmarktperspectieven van assistenten binnen de branche. Integendeel, juist assistenten die vaker werkzaamheden uitvoeren die tot de kerntaken van hun functie behoren, zoals standaard baliecontacten en medicijnen dispenseren, denken dat het gemakkelijker is om elders binnen de branche een minstens even aantrekkelijke baan te vinden. Hieruit zou geconcludeerd mogen worden dat de arbeidsmarktperspectieven van assistenten binnen de branche meer verbeteren door het goed uitoefenen van de werkzaamheden die tot de functie van apothekersassistent behoren dan door taken te verrichten die niet tot hun functie behoren. Het is dan ook opvallend dat het competentieniveau van apothekersassistenten, en dan met name op het gebied van de sectorspecifieke competenties, de

42. A. de Grip en J.D. Vlasblom (1999). Toekomstverkenning arbeidsmarkt apothekersassistenten in de openbare apotheek. ROA-R-1999/7, Maastricht. 
arbeidsmarktperspectieven binnen de branche niet beï nvloeden. Dit zou overigens verklaard kunnen worden uit de eerdere constatering dat de assistenten met betere sectorspecifieke competenties zich al voldoende gewaardeerd voelen in hun huidige functie, zoals bleek uit het hogere salaris dat ze verdienen en hun grotere tevredenheid met hun huidige baan.

Schema 6.5

Belangrijkste factoren die van invloed zijn op de arbeidsmarktperspectieven binnen de branche van apothekersassistenten in de openbare apotheek, 2001

Betere arbeidsmarktperspectieven binnen de branche voor assistenten die:

- overwerk verrichten

- vaker werkzaamheden als standaard baliecontacten en medicijnen dispenseren uitvoeren

Slechtere arbeidsmarktperspectieven binnen de branche voor assistenten die:

- schoolverlater zijn

- in een zelfstandige apotheek werken

Bron: ROA

lemands werkervaring als apothekersassistent blijkt geen invloed te hebben op de arbeidsmarktperspectieven binnen de branche. Wel is het zo dat schoolverlaters hun arbeidsmarktperspectieven binnen de branche als slechter beschouwen dan de overige assistenten. Ten slotte blijken assistenten die in een zelfstandige apotheek werkzaam zijn het moeilijker te vinden om elders binnen de branche een minstens even aantrekkelijke baan te vinden.

\section{Schema 6.6}

Belangrijkste effecten op de arbeidsmarktperspectieven buiten de branche van apothekersassistenten in de openbare apotheek, 2001

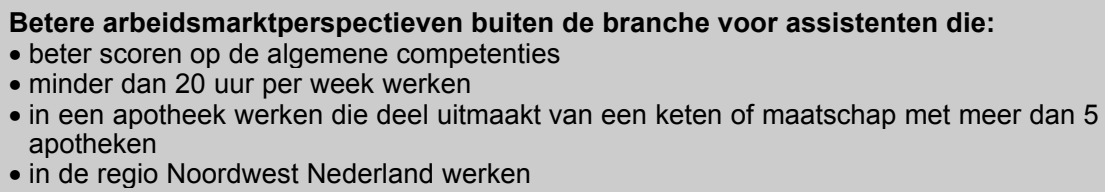

Slechtere arbeidsmarktperspectieven buiten de branche voor assistenten die:

- een sectorspecifieke cursus gevolgd hebben

- een algemene cursus gevolgd hebben

- schoolgaande kinderen hebben (jongste kind in de leeftijd 3 tot 15 jaar)

Bron: ROA

Zijn op de arbeidsmarktperspectieven van apothekersassistenten buiten de branche dezelfde factoren van invloed? Schema 6.6 laat zien dat dit niet het geval is. Bij de arbeidsmarktperspectieven buiten de branche is het competentieniveau namelijk wel van belang. Hoe beter apothekersassistenten scoren op de algemene competenties, des te gemakkelijker denken zij een minstens even aantrekkelijke baan elders buiten de branche te vinden. Het is aannemelijk dat algemene competenties als communicatieve vaardigheden, zelfstandigheid, omgaan met verantwoordelijkheid en omgaan met collega's ook buiten de branche van nut zijn, Dit in tegenstelling tot de sector- 
specifieke competenties die in principe alleen binnen de branche van belang zijn. Deze laatste competenties beï nvloeden de arbeidsmarktperspectieven van apothekersassistenten buiten de branche dan ook niet. Wel blijken assistenten die recent sectorspecifieke cursussen gevolgd hebben hun perspectieven buiten de branche als slechter beoordelen. Opmerkelijk is echter dat hetzelfde ook geldt voor assistenten die recent een algemene cursus gevolgd hebben.

Flexibele of breed inzetbare apothekersassistenten schatten hun arbeidsmarktperspectieven buiten de branche niet beter of slechter in dan minder employabele assistenten. Wel denken assistenten die minder dan 20 uur per week werken gemakkelijk een even aantrekkelijke baan buiten de branche te vinden. Ook assistenten die in een apotheek werken die deel uitmaakt van een keten of maatschap met meer dan 5 apotheken schatten hun arbeidsmarktperspectieven buiten de branche als beter in. Hetzelfde geldt voor de assistenten die in de regio Noordwest werken. Dit spoort met de over het algemene krappere arbeidsmarkt in deze regio. Assistenten met schoolgaande kinderen denken daarentegen dat het moeilijker is om een baan buiten de branche te vinden. Kennelijk is voor deze groep assistenten het werken in de apothekersbranche een aantrekkelijke optie.

We kunnen dus concluderen dat de employability van apothekersassistenten hun arbeidsmarktperspectieven slechts in beperkte mate beï nvloedt. Het is interessant te onderzoeken welke effecten scholing, flexibiliteit en brede inzetbaarheid nu hebben op het daadwerkelijke zoekgedrag van assistenten. Uit hoofdstuk $5 \mathrm{kwam}$ naar voren dat op het moment van de enquête (november/december 2001) één op de tien apothekersassistenten in de openbare apotheek actief op zoek is naar een andere baan. Zijn assistenten die meer employabel zijn eerder op zoek naar een andere baan?

In schema 6.7 staan de belangrijkste effecten op dit zoekgedrag van assistenten. Het blijkt dat - zoals verwacht mocht worden - assistenten die tevreden zijn met hun werk minder snel op zoek gaan naar een andere baan. Willen apothekers hun assistenten behouden, dan is het dus zaak om voldoende aandacht te hebben voor hun tevredenheid met hun werk. Uit de vorige paragraaf bleek dat hiervoor met name het laten uitvoeren van farmaceutische taken van de apotheker, regelmatig eentonig werk verrichten en het regelmatig onder een hoge tijdsdruk werken zoveel mogelijk vermeden moeten worden. Het regelmatig te maken hebben met lichamelijk zwaar werk leidt er niet toe dat assistenten minder tevreden zijn met hun werk, maar blijkt er wel aan bij te dragen dat assistenten eerder ander werk gaan zoeken. Daarnaast blijkt dat assistenten die vaker besteltaken en overige taken als etalagebeheer, schoonmaken en bezorgen uitvoeren eerder op zoek gaan naar een andere baan. Deze taken worden door assistenten ook als minder plezierig ervaren dan de basistaken (zie hoofdstuk 5).

Een andere mogelijkheid voor apothekers die graag apothekersassistenten willen behouden is om hen flexibele werktijden aan te bieden. Apothekersassistenten werken graag in deeltijd om zo werk en zorgtaken te kunnen combineren. Dat apothekers die dit HRM instrument inzetten aantrekkelijke werkgevers gevonden wor- 
den, bleek ook al uit het werkgeversonderzoek. Zij hebben beduidend minder met knelpunten in de personeelsvoorziening te maken.

\section{Schema 6.7}

Belangrijkste factoren die van invloed zijn op het zoekgedrag van apothekersassistenten in de openbare apotheek, 2001

\section{Eerder op zoek naar een andere baan voor assistenten die:}

- regelmatig met lichamelijk zwaar werk te maken hebben

- vaker werkzaamheden verrichten als besteltaken en overige taken

Minder snel op zoeken naar een andere baan voor assistenten die:

- tevreden zijn met hun werk

- in een apotheek werken waar flexibele werktijden aangeboden worden

Bron: ROA

Het is ook opmerkelijk dat het volgen van cursussen geen effect op het zoekgedrag van apothekersassistenten heeft. Ook het competentieniveau van assistenten blijkt er niet toe te doen. Dit is goed nieuws voor de apothekers: competente assistenten zullen niet eerder op zoek gaan naar een andere baan dan de minder competente assistenten. We hebben bij de analyse naar de effecten op het zoekgedrag van apothekersassistenten geen onderscheid kunnen maken in het zoeken naar een baan als assistent in een andere openbare apotheek, een baan als assistent buiten de openbare apotheek, of een baan in een andere functie binnen of buiten de sector. Het aantal apothekersassistenten dat in deze verschillende categorieën valt is te klein om uitspraken over te doen. Een dergelijk onderscheid is echter wel interessant, omdat de redenen die achter dit zoekgedrag liggen, zeer verschillend kunnen zijn. 



\section{Bijlage A: De enquête}

In het kader van het in dit rapport beschreven onderzoek is in november en december 2001 door bureau Intomart een enquête gehouden onder gediplomeerde apothekersassistenten die werkzaam zijn in de openbare apotheek. De vragenlijst van deze enquête is te vinden in bijlage $B$. De namen en adressen van de apothekersassistenten zijn afkomstig uit het pensioenbestand van het Pensioenfonds Medewerkers Apotheken (PMA). Na verwijdering van dubbele records en enkele apothekersassistenten die in het buitenland woonachtig zijn, telt dit bestand 12.523 apothekersassistenten die werkzaam zijn in de openbare apotheek. Uit deze totale populatie van apothekersassistenten is een aselecte steekproef getrokken van 5.950 personen, aan wie een schriftelijke vragenlijst toegezonden is.

lets meer dan de helft van de aangeschreven apothekersassistenten (54\%) heeft de enquête ingevuld en teruggestuurd. Van deze 3.229 respondenten is na te gaan of zij een representatieve afspiegeling vormen van de totale populatie van apothekersassistenten werkzaam in de openbare apotheek. De eerste kolom in Tabel A1 laat de verdeling van de totale populatie naar geslacht, leeftijd en regio ${ }^{43}$ zien. Apothekersassistenten blijken vrijwel allemaal vrouw te zijn (99\%), en veelal in de leeftijd 25 tot 40 jaar $(50 \%)$. In de regio Noord Nederland zijn de minste apothekersassistenten werkzaam (9\%). De tweede kolom van de tabel geeft de cijfers voor de ongewogen responsgroep, dat wil zeggen voor de apothekersassistenten die aan de enquête hebben deelgenomen. Vergelijking van de percentages in de twee kolommen laat zien dat er slechts kleine verschillen zijn in de verdeling naar geslacht, leeftijd en regio tussen de totale populatie en de responsgroep. Om deze verschillen recht te trekken is de responsgroep gewogen op basis van geslacht, leeftijd en regio. De derde kolom van Tabel A1 laat zien dat deze gewogen responsgroep een bruikbare afspiegeling vormt van de apothekersassistenten werkzaam in de openbare apotheek. 
Tabel A1

Verdeling van de totale populatie, de ongewogen responsgroep en de gewogen responsgroep naar geslacht, leeftijd en regio

\begin{tabular}{|c|c|c|c|c|c|c|}
\hline \multirow[t]{2}{*}{ Kenmerk } & \multicolumn{2}{|c|}{$\begin{array}{l}\text { Totale } \\
\text { populatie }\end{array}$} & \multicolumn{2}{|c|}{$\begin{array}{l}\text { Ongewogen } \\
\text { responsgroep }\end{array}$} & \multicolumn{2}{|c|}{$\begin{array}{c}\text { Gewogen } \\
\text { responsgroep }\end{array}$} \\
\hline & aantal & $\%$ & aantal & $\%$ & aantal & $\%$ \\
\hline \multicolumn{7}{|l|}{ Geslacht } \\
\hline Man & 107 & 1 & 27 & 1 & 29 & 1 \\
\hline Vrouw & 12.416 & 99 & 3.202 & 99 & 3.201 & 99 \\
\hline Totaal & 12.523 & 100 & 3.229 & 100 & 3.229 & 100 \\
\hline \multicolumn{7}{|l|}{ Leeftijd } \\
\hline 15-19 jaar & 83 & 1 & 18 & 1 & 21 & 1 \\
\hline 20-24 jaar & 1.867 & 15 & 433 & 13 & 471 & 15 \\
\hline 25-29 jaar & 2.404 & 19 & 602 & 19 & 620 & 19 \\
\hline 30-34 jaar & 1.984 & 16 & 522 & 16 & 520 & 16 \\
\hline 35-39 jaar & 1.843 & 15 & 492 & 15 & 473 & 14 \\
\hline 40-44 jaar & 1.563 & 13 & 419 & 13 & 402 & 12 \\
\hline 45-49 jaar & 1.253 & 10 & 341 & 11 & 329 & 10 \\
\hline 50-54 jaar & 978 & 8 & 258 & 8 & 250 & 8 \\
\hline 54-59 jaar & 424 & 3 & 108 & 3 & 111 & 3 \\
\hline $60-64$ jaar & 123 & 1 & 36 & 1 & 36 & 1 \\
\hline 65 jaar en ouder & 1 & 0 & 0 & 0 & 0 & 0 \\
\hline Totaal & 12.523 & 100 & 3.229 & 100 & 3.229 & 100 \\
\hline \multicolumn{7}{|l|}{ Regio } \\
\hline Noord Nederland & 1.179 & 9 & 278 & 9 & 305 & 9 \\
\hline Oost Nederland & 2.626 & 21 & 619 & 19 & 680 & 21 \\
\hline Noordwest Nederland & 1.795 & 14 & 308 & 10 & 459 & 14 \\
\hline Middenwest Nederland & 2.432 & 19 & 673 & 21 & 624 & 19 \\
\hline Zuidwest Nederland & 2.447 & 20 & 757 & 23 & 635 & 20 \\
\hline Zuidoost Nederland & 2.044 & 16 & 594 & 18 & 527 & 16 \\
\hline Totaal & 12.523 & 100 & 3.229 & 100 & 3.229 & 100 \\
\hline
\end{tabular}




\section{Bijlage B: Vragenlijst}

\section{APOTHEKERSASSISTENTEN IN DE OPENBARE APOTHEEK}

\section{Blok 1 Algemene informatie}

In dit eerste vragenblok willen we u een aantal algemene vragen stellen over uzelf en over uw gezinssituatie.

1. Bent u man of vrouw?
$1 \square \operatorname{man}$
$2 \square$ vrouw

2. Wat is uw leeftijd?

jaar

$12 \mathrm{~L} 2$

3. Heeft $u$ een partner waarmee $u$ een gezamenlijke huishouding voert?

$1 \quad \square$ ja

$2 \square$ nee $\rightarrow$ GA VERDER MET VRAAG 5

werkzaam in een voltijdbaan

$2 \square$ werkzaam in een deeltijdbaan (32 uur of minder)

$3 \square$ huishoudelijk werk / zorgtaken

$4 \square$ werkzoekende

$5 \square$ studerend

$6 \quad \square$ arbeidsongeschikt

$7 \square$ VUT / pensioen

$8 \square$ anders, nameli

5. Heeft u thuiswonende kinderen?

$1 \square \mathrm{ja}$, ik heb .......... kinderen thuiswonen

$2 \square \quad$ nee $\rightarrow$ GA VERDER MET BLOK 2

6. Hoe oud is uw jongste thuiswonende kind?

Blok 2 Opleiding en werkervaring

De volgende vragen gaan over de opleiding(en) die u gevolgd heeft en over uw werkervaring.

7. In welk jaar heeft u uw opleiding tot apothekersassistent afgerond?

8. Hoeveel jaar werkervaring heeft u? (TEL ALLE JAREN DAT U BETAALDE ARBEID VERRICHTTE, IN WELKE FUNCTIE DAN OOK, MEE. LAAT BUITEN BESCHOUWING OF U AL DAN NIET IN DEELTIJD WERKTE)

............ jaar

9. En hoeveel jaar heeft $u$ in totaal gewerkt als apothekersassistent? 
Dit blok bestaat uit vragen over uw huidige werksituatie als apothekersassistent in de openbare apotheek. Wanneer u in meerdere openbare apotheken werkt, ga dan uit van uw werksituatie in de openbare apotheek waar u het grootste arbeidscontract mee heeft.

10. Sinds wanneer werkt u bij deze apotheek? (VUL HET JAAR VAN INDIENSTTREDING IN)

11. Heeft $u$ een vast of een tijdelijk contract, of werkt $u$ op oproepbasis?

$\square$ vast contract

$2 \square$ tijdelijk contract met uitzicht op vaste aanstelling

$3 \square$ tijdelijk contract

$4 \square$ oproepbasis $\rightarrow$ GA VERDER MET VRAAG 13

12. Voor hoeveel uur per week bent u volgens uw contract in dienst?$$
\text { ............ uur per week }
$$

13. Hoeveel uur werkt $u$ feitelijk gemiddeld per week?

$$
\text { .......... uur per week }
$$

14. En hoeveel uur per week zou u het liefst willen werken?

15. Maakt u gebruik van de seniorenregeling?

$1 \square$ ja

$2 \square$ nee

$39 L 1$

16. De volgende vraag gaat over uw werktijden. Wilt $u$ aangeven of de onderstaande kenmerken doorgaans gelden voor het werk dat u doet?

regelmatige werktijden, alleen overdag

$\begin{array}{cc}\text { ja } & \text { nee } \\ 1 & 2\end{array}$

regelmatige werktijden, met dag-, avond-, nacht- en/of weekenddiensten volgens vast patroon

onregelmatige werktijden met dag-, avond-, nacht- en/of weekenddiensten volgens wisselend patroon (door werkgever bepaald)

werken op zaterdag

werken op zondag

avond- of nachtdiensten

aanwezigheiddienst in de avond en op zaterdag en zondag

bereikbaarheidsdienst

17. Hoeveel uur per week besteedt u gemiddeld aan onderstaande werkzaamheden? (HET IS DE BEDOELING DAT DE ANTWOORDEN TOTAAL OPTELLEN TOT HET AANTAL UREN DAT U PER WEEK WERKT. WANNEER U BEPAALDE WERKZAAMHEDEN NIET UITVOERT, VUL DAN O IN)

Werkzaamheden:

$$
\text { aantal uur: }
$$


Bereiding (magistrale bereiding van medicijnen, voorraadbereiding)

Besteltaken (beheer bestelmodel, bestellingen plaatsen, controleren en

Farmaceutische patiëntenzorg (intensieve baliecontacten, geven van diepgaande farmaceutische toelichting bij aflevering/bezorgen van medicijnen, speciale spreekuren rond thema's als astma, diabetes

incontinentie, terminale zorg, medicijnbewaking)

Administratie (afhandelen en opbergen van recepten, nota's/rekeningen patiënten)

Financiën (loonadministratie, declaratieverkeer naar verzekeraars)

Overig (uiteenlopende activiteiten als werkoverleg, etalagebeheer, schoonmaak, bezorgen etc.)

Totaal

18. Verricht $\mathrm{u}$ in uw huidige baan wel eens werkzaamheden die strikt genomen niet bij uw functie horen?

$1 \square \mathrm{ja}$, farmaceutische taken van de apotheker

$\square \mathrm{ja}$, management taken (administratie/personeelszaken) $\quad 67 \mathrm{~L} 1$

$\square \mathrm{ja}$, taken uit andere functies $\quad 68 \mathrm{~L} 1$

$1 \square$ nee $199 \mathrm{~L} 1$

19. Wat is uw persoonlijke inkomen per maand uit deze baan?

$\begin{array}{llll} & & 70 \mathrm{~L} 4 \\ \text { bruto: } f & . . . \ldots \ldots \ldots . . . & \text { netto: } f \ldots \ldots \ldots \ldots & 74 \mathrm{~L} 4\end{array}$

20. Maakt u gebruik van de regeling kinderopvang zoals bedoeld in de CAO Apotheken?
$1 \square$ ja
$2 \square$ nee
$78 \mathrm{~L} 1$

21. Hoeveel tijd kost het u gewoonlijk om van huis op het werk te komen? (VUL DE GEMIDDELDE ENKELE REISTIJD VAN DEUR TOT DEUR IN MINUTEN IN)

minuten

$79\llcorner 3$

22. Kunt u voor uw werk aangeven of u regelmatig, soms, of nooit te maken hebt met de volgende aspecten:

hoge tijdsdruk

lichamelijk zwaar werk

geestelijk zwaar werk

fysieke omstandigheden als lawaai, tocht, hoge of lage temperaturen, stof, etc.

$\begin{array}{ccc}\text { regelmatig } & \text { soms } & \text { nooit } \\ 1 & 2 & 3 \\ \square & \square & \square \\ \square & \square & \square \\ \square & \square & \square \\ \square & \square & \square \\ \square & \square & \square\end{array}$

23. Hoeveel dagen heeft $u$ de afgelopen 12 maanden van uw werk verzuimd wegens ziekte? (TEL ZWANGERSCHAPSVERLOF NIET MEE)

Indien u 0 dagen verzuimd hebt, ga dan verder met vraag 25

24. Lag de oorzaak van het laatste of huidige ziekteverzuim bij het werk of de werksituatie?

$1 \square$ ja, oorzaak lag geheel bij het werk

$2 \square$ ja, oorzaak had gedeeltelijk met het werk te maken

$3 \square$ nee, oorzaak had niet met het werk te maken 
25. Bent u de afgelopen jaren heringetreden als apothekersassistent?

$1 \square$ ja

$2 \square$ nee $\rightarrow$ GA VERDER MET BLOK 4

$91 \mathrm{~L} 1$

26. Wat waren bij uw beslissingen om opnieuw als apothekersassistent te gaan werken positieve en negatieve overwegingen?

mogelijkheid tot deeltijdwerk

negatieve

overweging heeft overweging overweging niet meege-

1

mogelijkheid tot flexibele werktijden

2

gevraagd door vriendin of oud collega

terug in het vak willen

mogelijkheid om zorg voor kinderen, huishoudelijk werk of andere zorgtaken met werk te combineren

onregelmatige diensten

beschikbaarheid van kinderopvang of buitenschool-

se opvang

loopbaanperspectieven

financiële beloning

reistijd

werksfeer

anders, namelijk:

$\square \quad \square \quad \square$

$\square \quad 92$

$\square \quad \square \quad 93$

$\square \quad \square \quad 94$

$\square \quad \square \quad 95$

$\square \quad \square \quad 96$

$\square \quad \square \quad 97$

$\square \quad \square \quad 98$

anders, name

$\square \quad \square \quad 99$

$\square \quad \square \quad 100$

$\square \quad \square \quad 101$

$\square \quad \square \quad 102$

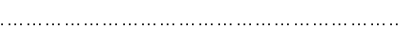

103

104L4

\section{Blok 4 Cursussen en vaardigheden}

In dit blok wordt gevraagd naar cursussen en trainingen die u eventueel gevolgd heeft, en naar uw kennis en vaardigheden.

27. Heeft u de afgelopen 12 maanden één of meerdere aan uw werk als apothekersassistent gerelateerde cursussen afgesloten? (HET GAAT DUS NIET OM EEN CURSUS DIE U OP DIT MOMENT VOLGT)
$1 \quad \square$ ja
$2 \square$ nee $\rightarrow$ GA VERDER MET VRAAG 33
108L1

28. De volgende vragen gaan over de laatste cursus die u volgde. Op welke terreinen lag deze cursus?
$\square$ geneesmiddelenkennis
$\square$ communicatieve vaardigheden en omgangskunde
$\square$ informatieverstrekking over geneesmiddelen
$1 \square$ computervaardigheden
$\square$ recepteren van geneesmiddelen
$\square$ bereiden van geneesmiddelen
$\square$ kennis ziektebeelden
$\square$ zelfstandigheid
$\square$ omgaan met verantwoordelijkheid
$\square$ omgaan met collega's

$1 \square$ anders, namelijk: 
29. Heeft u studiepunten met deze cursus verdiend?
$1 \square \mathrm{ja}, .$.
... studiepunten
$2 \square$ nee

30. Door wie is deze cursus betaald?

$1 \quad \square$ door mijzelf

128L1

$2 \square$ door de werkgever

$3 \square$ deels door mijzelf en deels door werkgever

31. Wat is de belangrijkste reden waarom u deze cursus volgde? (SLECHTS ÉÉN ANTWOORD AANKRUISEN)

$01 \square$ om mijn tekort aan kennis en vaardigheden weg te werken

$02 \square$ om bij te blijven

$03 \square$ om mij verder te specialiseren

$04 \square$ de cursus was verplicht

$05 \square$ om aan de cursus gekoppelde salarisverhoging

$06 \square$ om promotie te kunnen maken

$07 \square$ om ander werk te kunnen doen

$08 \square$ anders, namelijk:

32. Komt de in deze cursus opgedane kennis van pas in het werk in de openbare apotheek?

$1 \square \mathrm{ja}$, ik gebruik de opgedane kennis bij mijn werkzaamheden

$2 \square$ ja, collega's maken gebruik van de kennis die ik opdeed

$3 \square$ ja, zowel ik als collega's gebruiken de opgedane kennis bij ons werk

$4 \quad \square$ nee, de opgedane kennis komt niet van pas in het werk

33. Kunt u met een rapportcijfer tussen de 1 en 10 aangeven in hoeverre $u$ de volgende vaardigheden bezit? ( $1=$ AFWEZIG, $10=$ UITMUNTEND)

\begin{tabular}{ll} 
Vaardigheid: & Cijfer: \\
\hline geneesmiddelenkennis & $\ldots \ldots \ldots$ \\
\hline communicatieve vaardigheden en omgangskunde & $\ldots \ldots \ldots$ \\
\hline informatieverstrekking over geneesmiddelen & $\ldots \ldots \ldots$ \\
\hline computervaardigheden & $\ldots \ldots \ldots$ \\
\hline recepteren van geneesmiddelen & $\ldots \ldots \ldots$ \\
\hline bereiden van geneesmiddelen & $\ldots \ldots \ldots$ \\
\hline kennis van ziektebeelden & $\ldots \ldots \ldots$ \\
\hline zelfstandigheid & $\ldots \ldots \ldots$ \\
\hline omgaan met verantwoordelijkheid & $\ldots \ldots \ldots$ \\
\hline omgaan met collega's & $\ldots \ldots \ldots$
\end{tabular}


34. Op welke manier denkt u uw vaardigheden het beste op peil te houden: door zelfstudie, door het volgen van cursussen, door leren op de werkplek of door het leren van collega's in de apotheek? (PER VAARDIGHEID KUNT U SLECHTS ÉÉN ANTWOORD AANKRUISEN)

Vaardigheid
geneesmiddelenkennis
communicatieve vaardigheden en
omgangskunde
computervaardigheden
bereiden van geneesmiddelen

$\begin{array}{cc}\text { zelfstudie } & \begin{array}{c}\text { cursussen } \\ \text { volgen }\end{array} \\ 1 & 2 \\ \square & \square \\ \square & \square \\ \square & \square \\ \square & \square\end{array}$

leren
werk
3

leren van
collega's

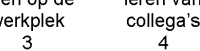

bereiden van geneesmiddelen

Blok 5 Werkzaamheden

De volgende vragen gaan over uw werkzaamheden.

35. Kunt u aangeven met hoeveel plezier $\mathrm{u}$ onderstaande werkzaamheden uitvoert? (VOOR EEN UITVOERIGE BESCHRIJVING VAN DE WERKZAAMHEDEN, ZIE VRAAG 17. WANNEER U BEPAALDE WERKZAAMHEDEN NIET UITVOERT, KRUIST U DAN "NIET VAN TOEPASSING" AAN)

$\begin{array}{lccccccc} & \begin{array}{c}\text { met veel } \\ \text { plezier }\end{array} & \text { met plezier } & \text { neutraal } & \begin{array}{c}\text { met weinig } \\ \text { plezier }\end{array} & \begin{array}{c}\text { met zeer } \\ \text { weinig } \\ \text { plezier }\end{array} & \begin{array}{c}\text { niet van } \\ \text { toepas- } \\ \text { sing }\end{array} & \\ \text { basistaken } & 1 & 2 & 3 & 4 & 5 & 6 & \\ \text { bereiding } & \square & \square & \square & \square & \square & \square & 156 \\ \text { besteltaken } & \square & \square & \square & \square & \square & \square & 157 \\ \text { farmaceutische patiëntenzorg } & \square & \square & \square & \square & \square & \square & 159 \\ \text { administratie } & \square & \square & \square & \square & \square & \square & 158 \\ \text { financiën } & \square & \square & \square & \square & \square & \square & 160 \\ \text { overige taken } & \square & \square & \square & \square & \square & \square & 161 \\ & \square & \square & \square & \square & \square & \square & 162\end{array}$

36. Wanneer uw werkgever daarom vraagt, bent u dan bereid om:

een cursus te volgen

meer uren te werken

werkzaamheden uit te voeren die strikt genomen niet bij uw functie horen, dat wil zeggen:

\footnotetext{
- farmaceutische taken van de apotheker

- management taken (administratie/personeelszaken)

- taken uit andere functies
} 


\section{Blok 6 Loopbaan}

We willen u nu enige vragen stellen over de verwachtingen die u heeft over uw eigen loopbaan.

37. Bent u momenteel (actief) op zoek naar een andere baan?

$1 \square \mathrm{ja}$, ik zoek een baan als apothekersassistent in een andere openbare apotheek 168

$2 \square$ ja, ik zoek een baan als apothekersassistent buiten de openbare apotheek 169

$3 \square \mathrm{ja}$, ik zoek een baan in een andere functie, maar wel binnen de sector $\quad 170$

$4 \quad \square$ ja, ik zoek een baan in een andere functie, maar dan buiten de sector $\quad 171$

$5 \square$ nee, ik ben niet op zoek naar een andere baan 172

38. Denkt u over 5 jaar nog als apothekersassistent in de openbare apotheek te werken? (KRUIS DE SITUATIE AAN DIE VOOR U HET MEEST WAARSCHIJNLIJK IS)

$1 \square \mathrm{ja}$, in dezelfde openbare apotheek als waar ik nu werk $\rightarrow$ GA VERDER MET VRAAG 40

$2 \square \mathrm{ja}$, maar wel in een andere openbare apotheek

$3 \square$ nee, dan werk ik als apothekersassistent buiten de openbare apotheek

$4 \quad \square$ ja, nee dan werk ik niet meer als apothekersassistent

$5 \square$ nee, dan ben ik gestopt met werken

39. Waarom denkt u over 5 jaar niet meer in uw huidige apotheek te werken? (MEERDERE ANTWOORDEN MOGELIJK)

$1 \square$ betere loopbaanperspectieven elders

$1 \square$ hoger salaris elders

$\square$ soort werk is niet bevredigend

$1 \square$ te weinig werk

$\square$ te lange reistijd

$1 \square$ te hoge werkdruk

$1 \square$ onregelmatige werktijden

$\square$ werksfeer

$\square$ werkomstandigheden / ARBO / omgaan met gevaarlijke stoffen

$\square$ wil een opleiding/studie gaan volgen

$1 \square$ zorg voor kinderen, huishoudelijk werk of andere zorgtaken

$\square$ gezondheidsproblemen/arbeidsongeschiktheid

$1 \square$ verhuizing

$\square$ onenigheid op de werkvloer

$\square$ ontslag door werkgever

$1 \square$ gestopt vanwege leeftijd / pensionering

$1 \quad \square$ anders, namelijk:

40. Hoe moeilijk is het volgens u om op dit moment elders binnen de branche een voor u minstens even aantrekkelijke baan te vinden?

$1 \square$ zeer moeilijk

$2 \square$ moeilijk

$3 \square$ neutraal

$4 \quad \square$ gemakkelijk

$5 \square$ zeer gemakkelijk

$6 \quad \square$ weet niet 
41. Hoe moeilijk is het volgens u om op dit moment elders buiten de branche een voor u minstens even aantrekkelijke baan te vinden?
$\square$ zeer moeilijk
$2 \square$ moeilijk
$3 \square$ neutraal
$4 \quad \square$ gemakkelijk
$5 \square$ zeer gemakkelijk
$6 \square$ weet niet

Blok 7 Tevredenheid werksituatie

In dit blok willen we u vragen hoe tevreden u bent met uw huidige baan, met verschillende aspecten van uw werk en met het personeelsbeleid van uw werkgever.

42. Bent $u$, alles bijeengenomen, tevreden met uw huidige baan?
$1 \square$ zeer tevreden
$2 \square$ wel tevreden
$3 \square$ niet zo tevreden
$4 \quad \square$ helemaal niet tevreden

43. Hoe tevreden bent u over de volgende aspecten van uw werk?

$\begin{array}{lccccc} & \text { zeer tevreden } & \text { wel tevreden } & \begin{array}{c}\text { niet zo } \\ \text { tevreden }\end{array} & \begin{array}{c}\text { helemaal niet } \\ \text { tevreden }\end{array} & \\ \text { salaris } & 1 & 2 & 3 & 4 & 198 \\ \text { werktijden } & \square & \square & \square & \square & 199 \\ \text { zelfstandigheid } & \square & \square & \square & \square & 200 \\ \text { werksfeer } & \square & \square & \square & \square & 201 \\ \text { werkdruk } & \square & \square & \square & \square & 202 \\ \text { inhoud van het werk } & \square & \square & \square & \square & 203 \\ \text { loopbaanperspectieven } & \square & \square & \square & \square & 204 \\ \text { scholingsfaciliteiten } & \square & \square & \square & \square & 205 \\ \text { veiligheid op werkplek } & \square & \square & \square & \square & 206 \\ \text { leiding geven door apotheker } & \square & \square & \square & \square & 207\end{array}$

44. En hoe tevreden bent u over de hieronder genoemde aspecten van het personeelsbeleid van uw werkgever? (KRUIS "NIET VAN TOEPASSING" AAN WANNEER U ER GEEN GEBRUIK VAN MAAKT)

\begin{tabular}{|c|c|c|c|c|c|c|}
\hline & $\begin{array}{c}\text { zeer tevreden } \\
1\end{array}$ & $\begin{array}{c}\text { wel tevreden } \\
2\end{array}$ & $\begin{array}{c}\text { niet zo } \\
\text { tevreden } \\
3\end{array}$ & $\begin{array}{c}\text { helemaal niet } \\
\text { tevreden } \\
4\end{array}$ & $\begin{array}{c}\text { niet van } \\
\text { toepassing } \\
5\end{array}$ & \\
\hline extra kleedgeld & $\square$ & $\square$ & $\square$ & $\square$ & $\square$ & 208 \\
\hline reiskostenregeling & $\square$ & $\square$ & $\square$ & $\square$ & $\square$ & 209 \\
\hline $\begin{array}{l}\text { aanvullingen op kinderopvang- } \\
\text { regeling CAO }\end{array}$ & $\square$ & $\square$ & $\square$ & $\square$ & $\square$ & 210 \\
\hline verlofsparen & $\square$ & $\square$ & $\square$ & $\square$ & $\square$ & 211 \\
\hline PC-privé project & $\square$ & $\square$ & $\square$ & $\square$ & $\square$ & 212 \\
\hline fietsenplan & $\square$ & $\square$ & $\square$ & $\square$ & $\square$ & 213 \\
\hline
\end{tabular}




\begin{tabular}{|c|c|c|c|c|c|c|}
\hline & $\begin{array}{c}\text { zeer tevreden } \\
1\end{array}$ & $\begin{array}{c}\text { wel tevreden } \\
2\end{array}$ & $\begin{array}{c}\text { niet zo } \\
\text { tevreden } \\
3\end{array}$ & $\begin{array}{c}\text { helemaal niet } \\
\text { tevreden } \\
4\end{array}$ & $\begin{array}{l}\text { niet van } \\
\text { toepassing } \\
5\end{array}$ & \\
\hline spaarloonregeling & $\square$ & $\square$ & $\square$ & $\square$ & $\square$ & 214 \\
\hline $\begin{array}{l}\text { persoonlijk ontwikkelingsplan } \\
\text { (POP) }\end{array}$ & $\square$ & $\square$ & $\square$ & $\square$ & $\square$ & 215 \\
\hline bedrijfsontwikkelingsplan (BOP) & $\square$ & $\square$ & $\square$ & $\square$ & $\square$ & 216 \\
\hline functioneringsgesprekken & $\square$ & $\square$ & $\square$ & $\square$ & $\square$ & 217 \\
\hline werkoverleg & $\square$ & $\square$ & $\square$ & $\square$ & $\square$ & 218 \\
\hline $\begin{array}{l}\text { extra beloning voor succesvol } \\
\text { afronden van cursus }\end{array}$ & $\square$ & $\square$ & $\square$ & $\square$ & $\square$ & 219 \\
\hline prestatiebeloning & $\square$ & $\square$ & $\square$ & $\square$ & $\square$ & 220 \\
\hline verzuimbegeleiding & $\square$ & $\square$ & $\square$ & $\square$ & $\square$ & 221 \\
\hline leeftijdsbewust personeelsbeleid & $\square$ & $\square$ & $\square$ & $\square$ & $\square$ & 222 \\
\hline flexibele werktijden & $\square$ & $\square$ & $\square$ & $\square$ & $\square$ & 223 \\
\hline \multirow[t]{3}{*}{ anders, namelijk: } & $\square$ & $\square$ & $\square$ & $\square$ & $\square$ & 224 \\
\hline & & & & & & $225 \mathrm{~L} 2$ \\
\hline & & & & & & $227 \mathrm{~L} 2$ \\
\hline
\end{tabular}

\section{Blok 8 Meningen en verwachtingen}

In dit blok vragen wij uw mening over eventuele veranderingen in uw werk als apothekersassistent.

45. Op welk terrein doen zich volgens u de belangrijkste veranderingen in uw werk als apothekersassistent voor? (MEERDERE ANTWOORDEN MOGELIJK)

$1 \square$ geen veranderingen

$\square$ verzorgen van spreekuren

$1 \square$ mondigheid van cliënten

$1 \square$ intensieve patiëntenvoorlichting

$1 \quad \square$ klantgerichtheid

$1 \square$ verplaatsen van farmaceutische zorg naar thuissituatie

1 uitbreiden handverkoop

$1 \square$ minder bereidingen

$1 \square$ snellere vernieuwing productaanbod

$1 \square$ vereiste geneesmiddelenkennis

$1 \square$ verticale functiedifferentiatie (bijv. taken overnemen van apotheker of apotheek medewerker)

$1 \square$ horizontale functiedifferentiatie (taken overnemen van andere apothekersassistent, bijv. specialisatie)

$1 \square$ verhoging van de werklast

$1 \square$ verlaging van de werklast

$1 \square$ kleine organisatorische veranderingen

$1 \square$ reorganisatie

$1 \square$ fusie/samenwerkingsvormen

$1 \square$ gebruik van nieuwe computersystemen

$1 \square$ koppeling met artsensysteem

$1 \square$ anders, namelijk: 
46. Heeft u moeite om zich aan deze veranderingen aan te passen?

$1 \quad \square$ zeer veel moeite

$2 \square$ veel moeite

$3 \square$ enige moeite

$4 \square$ vrijwel geen moeite

$5 \square$ geen moeite $\rightarrow$ GA VERDER MET BLOK 9

47. Wat is voor $u$ het belangrijkste probleem bij het aanpassen van deze veranderingen? (SLECHTS ÉÉN ANTWOORD AANKRUISEN)

$\square$ gebrekkige communicatie met leidinggevende apotheker

$2 \square$ vakinhoudelijk

$3 \square$ tijdgebrek

$4 \quad \square$ te weinig begeleiding

$5 \square$ omschakeling

$6 \quad \square$ anders, namelijk:

\section{Blok 9 Postcode}

Graag willen we de postcode weten van de apotheekvestiging waar u werkt. We zullen deze postcode gebruiken om informatie van categorieën werknemers en categorieën werkgevers aan elkaar te relateren. In geen geval zal er een koppeling van individuele gegevens plaatsvinden of informatie aan uw werkgever worden doorgegeven. Al de door u gegeven antwoorden blijven gegarandeerd anoniem!

48. Wat is de postcode van de apotheekvestiging waar u werkt? (LET OP: GEEN POSTCODE DIE BIJ EEN POSTBUSNUMMER HOORT)

Hartelijk bedankt voor uw medewerking aan deze vragenlijst!

Tot slot vragen we uw aandacht voor het volgende. Om ontwikkelingen in de apothekersbranche te kunnen meten, zal er in de toekomst een panel opgezet worden. Apothekersassistenten die meewerken aan dit panel zullen benaderd worden om een paar aanvullende vragen over werken in de openbare apotheek te beantwoorden. Vanzelfsprekend zullen ook deze antwoorden vertrouwelijk en anoniem behandeld worden. Zou u bereid zijn aan een dergelijk panel mee te werken? 